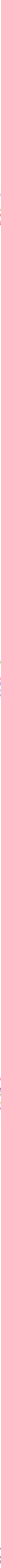



Lotte Hedegaard-Sørensen og Søren Langager

\section{Samarbejdets kunst}

Arbejdsfællesskaber og samarbejdsrelationer på specialskoler

Institut for Uddannelse og Pædagogik (DPU), Aarhus Universitet, 2012 
Titel:

Samarbejdets kunst - arbejdsfællesskaber og samarbejdsrelationer på specialskoler

Forfattere:

Lotte Hedegaard-Sørensen og Søren Langager

Udgivet af:

Forskningsprogrammet SSIP - Social- og Specialpædagogik i Inkluderende Perspektiv.

Aarhus Universitet, Institut for Uddannelse og Pædagogik (DPU), 2012

(C) 2012, forfatterne

1. udgave

Kopiering tilladt med tydelig kildeangivelse

Omslag og grafisk tilrettelæggelse: Knud Holt Nielsen

ISBN:

978-87-7430-270-4

978-87-7430-269-8 (elektronisk udgave)

DOI:

10.7146/aul.40.23

Rapporten samt $\varnothing$ vrige udgivelser fra SSIP kan gratis downloades via adressen www.dpu.dk/ssip/ebog 


\section{Indhold}

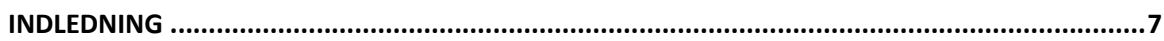

KAPITEL 1. UNDERS ØGELSENS EMPIRI, MÅL OG DESIGN ....................................................

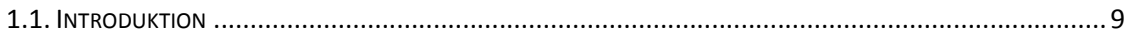

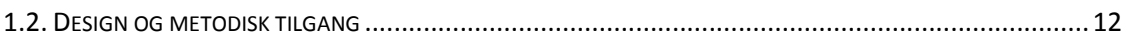

KAPITEL 2. ROLLER I SPECIALPAEDAGOGISK ARBEJDE...........................................................21

KAPITEL 3. ROLLEFORDELING MELLEM LAERERE OG PAEDAGOGMEDHJAELPERE ..........................30

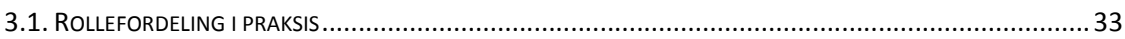

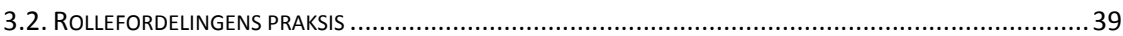

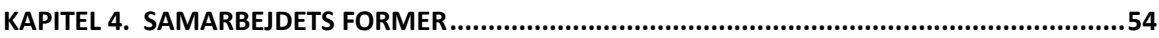

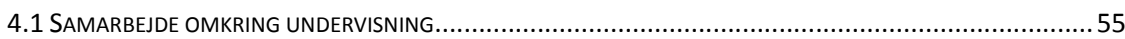

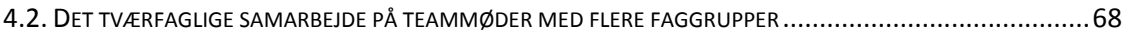

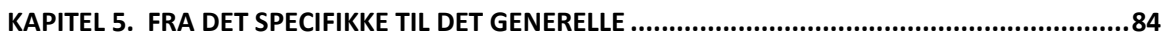

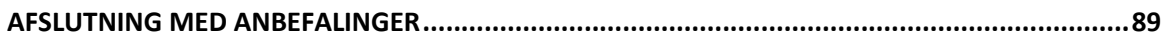

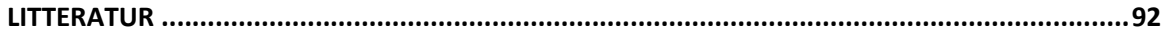

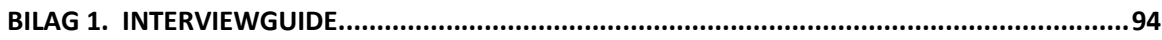

BILAG 2. FOKUSGRUPPEINTERVIEW - ROLLER OG INTERVIEWGUIDE ..................................96 



\section{Indledning}

Undersøgelsen 'Samarbejdets kunst' har fokus på samarbejdsrelationer, ansvars- og arbejdsopgavefordelinger og pædagogiske rolleforskelle mellem pædagogmedhjælpere og lærere på specialskoler.

I relation til den udbredte praksis på specialskoler og i andre specialpædagogiske institutioner til at forskellige faggrupper samarbejder omkring og $\mathrm{i}$ praksis, er den forskningsmæssige opmærksomhed på tværfaglighed og samarbejdsrelationer forholdsvist ubetydelig. I forskningsprogrammet 'Social- og Specialpædagogik i Inkluderende Perspektiv' (SSIP) på DPU var det derfor en kærkommen mulighed for at følge op på en forskningsmæssig interesse for samarbejde i specialpædagogisk praksis, at FOA (fagforbundet Fag og Arbejde) bad os igangsætte en undersøgelse om netop samarbejde mellem faggrupper på specialskoler.

I indeværende empiriske undersøgelse har opmærksomheden rettet sig mod samarbejdet mellem pædagogmedhjælpere og lærere på en specifik specialskole for børn med multiple funktionsnedsættelser. Det er et arbejdsfelt, som er karakteriseret ved at rumme både læring samt omsorg og pædagogik, og som derfor i udgangspunktet er organiseret med deltagelse af flere faggrupper: Lærere, pædagoger og pædagogmedhjælpere. Og det er et arbejdsfelt, som har lange traditioner for at samarbejde, hvorfor det har været muligt at producere empiriske indsigter om praksis og i relation til netop tværfagligt samarbejde i tæt relation til en specifik specialpædagogisk opgave.

Projekt 'Samarbejdets kunst - arbejdsfællesskaber og samarbejdsrelationer på specialskoler' er gennemført i perioden fra september 2010 til september 2011 af adjunkt, ph.d. Lotte Hedegaard-Sørensen og lektor, cand.mag. Søren Langager, begge ansat på DPU, Aarhus Universitet. Lotte Hedegaard-Sørensen har været hovedaktør i projektet, såvel i forhold til de empiriske observationer og interview som i forhold til udformning af projektrapporten, der er disponeret i fem kapitler:

- Kapitel 1 starter med en kort introduktion til specialskoleområdet, hvorefter forskningsprojektets empiriske felt og de teoretisk-metodiske tilgange udfoldes.

- Kapitel 2 er en tematisk beskrivelse af den observerede rollefordeling mellem pædagogmedhjælpere og lærere. 
- Kapitel 3 udgør en analyse af rollefordelingen mellem lærere og pædagogmedhjælpere, sådan som de selv forstår deres rollefordeling fra interview. Fokus vil særligt rette sig mod relationen mellem det specialpædagogiske arbejdes karakter og pædagogmedhjælperes rolle i det bredere specialpædagogiske arbejde og specifikt i relation til undervisningen.

- Kapitel 4 har fokus på samarbejdets former. Dels vil det blive fremanalyseret, hvordan lærere og pædagogmedhjælpere samarbejder i praksis både omkring undervisningen i praksis, men også på møder, hvor undervisningen planlægges og evalueres. Også her vil der være fokus på pædagogmedhjælpernes rolle, men nu i det tværfaglige samarbejde.

- I kapitel 5 trækkes nogle af undersøgelsens konklusioner op og generaliserbarheden efterprøves via fokusanalyser af de tre gruppeinterview, som afslutningsvist i projektet blev foretaget med tredive TR-repræsentanter fra omkring tyve specialskoler på landsplan.

- Endelig følger en kort afslutning med fire anbefalinger.

De enkelte kapitler er skrevet, så de kan læses uafhængigt af de øvrige; dog anbefales det at orientere sig i de to begreber 'frontstage' og 'backstage' i kapitel 1, da de udgør gennemgående analysekategorier i rapporten.

DPU, Aarhus Universitet, oktober 2011 Lotte Hedegaard-Sørensen og Søren Langager 


\section{Kapitel 1. \\ Undersøgelsens empiri, mål og design}

\subsection{Introduktion}

På Danmarks 200 specialskoler $^{1}$, der rummer lidt over 12.000 elever $^{2}$, er ansat mere end 5.000 personer. Heraf udgør personalet med pædagogiske opgaver 1.600 personer (såvel fuldtids- som deltidsansatte), altså omkring $30 \%{ }^{3}$ Hvordan den pædagogiske faggruppe fordeler sig mellem uddannede pædagoger, specialpædagoger og pædagogmedhjælpere, foreligger der ikke præcise oplysninger om på landsplan.

Et skøn er, at typisk mere end en femtedel af de ansatte på specialskoler udgøres af pædagogmedhjælpere (evt. med AMU-kurser inden for specialområdet). ${ }^{4}$ Hvilke arbejdsopgaver og ansvarsområder, pædagogmedhjælperne varetager i specialskolernes praksis er omdrejningspunktet i indeværende undersøgelse, men et bud på en 'idealkompetent pædagogmedhjælper' kan læses i målbeskrivelsen af de særlige AMU-kurser målrettet pædagogmedhjælpere i specialskoler, der er en mulighed for faglig opkvalificering. Målbeskrivelsen med kurset beskrives således:

Med forståelse for elevens specifikke handicap og vanskeligheder kan deltageren i samarbejde med læreren beskrive, planlægge og udføre pædagogiske aktiviteter, der er udviklingsstøttende for eleven,

\footnotetext{
${ }^{1}$ I skoleåret 2008/09 var der 201 specialskoler og 555 specialklasser på landsplan (Center for ligestilling af handicappede (CLH): Notat om faglighed $i$ specialskoler og specialklasser, 2010).

${ }^{2}$ I 2008 var det eksakte tal 12.205 elever (Nyt fra Danmarks Statistik nr. 311, juli 2009).

${ }^{3}$ Skoleåret 2008/09 var det samlede antal ansatte 5.399, heraf 3.256 læreruddannede og 1.613 ikke læreruddannede med pædagogiske opgaver (A.M.B. Hornbek: Pædagogisk personale i grundskolen, Uni*C 4. september, 2009).

${ }^{4}$ I en undersøgelse gennemført af Bureau 2000 på foranledning af FOA i 2009 er opgjort andelen af pædagogmedhjælpere på "de 10 specialskoler, som har flest pædagogmedhjælpere". Her ligger den typisk mellem 25 og $35 \%$ (antal personer - dvs. såvel fuld- som deltidsansatte) (Bureau 2000: Pædagogmedhjælpere på specialområdet. Et notat fra Bureau 2000", Stencilat 2009:4).
} 
og som bidrager til, at undervisningens mål opfyldes. Deltageren har kendskab til den gældende lovgivning for området og forstår egen rolle i undervisningen. Deltageren erhverver sig grundlæggende viden om pædagogiske metoder og undervisningsstrategier, der tilgodeser elevens faglige udvikling, og som kan bidrage til, at eleven udvikler sociale og kommunikative færdigheder. Deltageren kan indgå i et konstruktivt samarbejde med forældre, samt lærere og andre relevante faggrupper, således at elevens læring og udvikling er i fokus." 5

En undersøgelse fra Bureau 2000 (2009) peger på, at deltagelse i undervisningsaktiviteter er den arbejdsopgave, der fylder mest i det daglige arbejde for pædagogmedhjælpere. I Bureau 2000 opgøres, at 55 \% af pædagogmedhjælpernes arbejdstid går til 'assistance i undervisningen' og 7 \% går til 'ene-undervisning' ${ }^{6}$ Andre undersøgelser peger i retning af, at grænsefladerne mellem 'traditionelle fag-faglige undervisningstimer' (CKF-undervisning7) og skemalagte undervisningstimer med mere 'socialpædagogisk indhold' kan være flydende $^{8}$, og en spørgeskemaundersøgelse blandt specialskoler og specialklasser fra 2009 peger entydigt på, at den samlede faglige opgave anses som en ligelig fordeling af fokus på 'fag-faglighed' og på 'specialpædagogisk faglighed' . 9

Specialskolernes pædagogiske og didaktiske faglighed og organisering af den daglige specialundervisning og anden specialpædagogisk bistand er således et område, der såvel er sammensat med hensyn til den faglige forståelse af de grundlæggende opgaver i forhold til de varierede grupper af elever med behov for særlig tilrettelagt undervisning og pædagogik, som med hensyn til de professionelle, der spænder fra specialuddannede lærere til pædagogmedhjæl-

\footnotetext{
${ }^{5}$ UddannelsesGuiden 2010 (www.ug.dk).

${ }^{6}$ Bureau 2000, 2009:13. Pga. lav svarprocent i spørgeskemaundersøgelsen skal svarmønstrene dog tolkes med varsomhed.

${ }^{7}$ Den del af de pædagogiske og didaktiske aktiviteter på specialskolerne, der er rettet mod de fælles læringsmål for hele folkeskolen som beskrevet i de 'Centrale Kundskabs- og Færdighedsmål'.

${ }^{8}$ Eksempelvis L. Hedegaard-Sørensens ph.d.-afhandling, hvori indgår observationsstudier fra en specialskole (L. Hedegaard-Sørensen. Pædagogiske og didaktiske rum for elever med diagnosen autismespektrumforstyrrelse - om læreres selvforståelse og handling $i$ (special )pædagogisk praksis, 2010).

${ }_{9}^{9} 79 \%$ svarer, at der er en ligelig fordeling mellem de to sider af den samlede indsats, mens $6 \%$ svarer 'mest fokus på fag-faglighed' og 15 \% 'mest fokus på specialpædagogisk faglighed', der ofte har et socialpædagogisk mål. Her indgår som nævnt både specialklasser og specialskoler, og der er en svag tendens til, at specialskoler har mere fokus på specialpædagogisk faglighed end specialklasserne (CLH 2010:5).
} 
pere uden kompetencegivende uddannelsesmæssige kvalifikationer i forhold til den specialpædagogiske opgave.

I forhold til hvad der tegner sig af mønstre og tendenser omkring de faglige forståelsesrammer, samarbejdsrelationer og opgave- og ansvarsfordeling i praksis på specialskolerne, er forskningsprojektet 'Samarbejdets kunst' et bidrag til øget indsigt i samarbejdet blandt faggrupperne.

Undersøgelsen er tilrettelagt som en kvalitativ empirisk undersøgelse baseret på observationer af praksis i samarbejdet mellem lærere og pædagogmedhjælpere og interview (se interviewguide i bilag 1) på en specialskole på Sjælland.

Specialskolen/afdelingen er en ud af tre afdelinger på en stor specialskole. Specialskolen/afdelingen arbejder med elever med multiple funktionsnedsættelser og generelle indlæringsvanskeligheder. Skolen udgøres af 6 klasser, som rummer 24 drenge og 28 piger i alderen 6-18 år. Undervisningsdelen består af 19 lærere og 11 pædagogmedhjælpere. SFO-delen har 11 pædagoger og 6 pædagogmedhjælpere ansat. Tilknyttet skolen er også fysioterapeuter, talepædagoger og psykologer. Skolen er organiseret sådan, at skoledelen foregår om formiddagen og SFO-delen foregår om eftermiddagen. I modsætning til heldagsskoler eller helhedsskoler, hvor samarbejdet mellem pædagoger og lærere er mere udfoldet og fordelt over en samlet skoledag, er denne skole delt mellem en skoledel, hvor primært lærere og pædagogmedhjælpere samarbejder fast (og hvor pædagoger i gennemsnit er til stede 2 dage om ugen) og en SFO-del, hvor pædagoger og få pædagogmedhjælpere samarbejder. I fokus for undersøgelsen er samarbejdet mellem lærere og pædagogmedhjælpere, hvorfor pædagogernes rolle kun i mindre omfang inddrages i undersøgelsen.

Specialskolen arbejder ud fra værdierne ansvarlighed, samarbejde, engagement, faglighed og kommunikation. Samarbejde, som er i centrum for denne undersøgelse defineres som "evnen til at indgå i et samspil med andre, hvor man i fællesskab definerer og løser opgaver" (Lindebladet, 2009).

Der er i undersøgelsens design valgt et fokus på dybden, frem for i bredden, idet én specialskole som nævnt udgør det primære empiriske datagrundlag. Den metodiske antagelse er, at der i analysen af det specifikke ligger mere generelle indsigter gemt. Dog er de mere generelle problematikker omkring pædagogmedhjælperes rolle og ansvar i det tværfaglige arbejde på specialskoler i undersøgelsen suppleret med fokusgruppeinterview med tredive tillidsrepræsentanter for pædagogmedhjælpere fra et bredt udsnit af danske specialskoler. Med udgangspunkt i oplæg om foreløbige resultater fra observation og interview fra én specialskole, har TR repræsentanterne udvekslet erfaringer og synspunkter om roller, som pædagogmedhjælpere indtager i specialskoler og om samarbejdet mellem faggrupper på specialskoler med henblik på at under- 
søge genkendeligheden hos en bredere skare af resultater fra én specialskole (se interviewspørgsmål i bilag 2).

\subsection{Design og metodisk tilgang}

Undersøgelsen bevæger sig imellem en opmærksomhed på det pædagogiske og didaktiske arbejde i praksis samt på samarbejdsrelationer og ansvars- og arbejdsopgavefordeling mellem fagpersoner. Det er en grundlæggende antagelse for måden undersøgelsen er tilrettelagt på, at arbejdets karakter (den samlede specialpædagogiske praksis) er medbestemmende for, hvordan rollefordelingen og samarbejdet planlægges og udføres. Den børnegruppe og den kontekst, som de forskellige faggrupper (lærere, pædagoger og pædagogmedhjælpere) arbejder med og i, er med andre ord bestemmende for, hvordan de fordeler roller, og hvordan de situationelt samarbejder.

I diskussioner omkring forskelle på professioner vil der ofte være nogle gennemgående og måske stereotype forestillinger om, hvad pædagoger, lærere og pædagogmedhjælpere kan og er. Det er forestillinger og definitioner, som tager udgangspunkt i de forskellige professioners faggrænser, som refererer til forskellige uddannelser. I denne undersøgelse vil opmærksomheden rette sig mod den måde aktører, der arbejder i praksis og samarbejder i og om denne praksis, selv forstår deres opgave, deres rolle og deres samarbejdsrelationer med andre faggrupper. Det betyder, at undersøgelsen giver opmærksomhed til flertydighed, kompleksitet, nuancer i forhold til, hvordan professioner og samarbejde kan forstås og kun i mindre grad lader sig begrænse af de mere umiddelbart genkendelige forestillinger om lærere, pædagoger og pædagogmedhjælpere. Fokus lægges især på pædagogmedhjælperes rolle i arbejdet og i samarbejdet. Pædagogmedhjælpernes rolle bliver fremanalyseret med fokus på, hvordan de indtager og tilbydes roller i samarbejdet med især lærere og i relation til den praksis samarbejdet er situeret i. Det betyder fx, at den teoretisk informerede målbeskrivelse af pædagogmedhjælperes rolle, som formuleres i tilknytning til AMU-kurser, ikke nødvendigvis er dækkende for den rolle, som pædagogmedhjælpere indtager i praksis. Undersøgelsen går med andre ord i radikal forstand ind og beskriver praksis og aktører i praksis indefra og nedefra og udfordrer fagpolitiske og/eller teoretiske forestillinger om profession og professionsgrænser.

\section{Studiet af socialt liv og rolle}

Undersøgelsens design trækker hovedsageligt på E. Goffmans teori om, hvordan det sociale liv kan studeres og også på P. Bourdieus teori om praksis og F. Barths teori om sammenhængen mellem faglige formål og institutionskultur. 
Her vil teorierne (særligt Goffman) blive præsenteret i relation til undersøgelsen.

Goffmans teori kan beskrives som en teori om socialt liv i forhold til sociale roller og kan bidrage både med inspiration til, hvordan socialt liv (fx i klasserum) kan studeres, og hvordan samarbejde kan forstås; dvs. rollefordeling og samarbejdsformer i praksis. Den anden inspiration til undersøgelsen er Pierre Bourdieus teori om handling. I korthed inviterer Bourdieus tilgang til, at menneskers praksis og forståelse af deres praksis ikke kan stå alene i en undersøgelse. Antagelsen er, at måden fx pædagogmedhjælpere og lærere positionerer sig og handler sammen ikke udelukkende er et produkt af deres bevidste valg eller formulerede principper og handleplaner. Altså at de indtager roller i arbejdet og i samarbejdet uafhængigt af den større sociale sammenhæng, de indgår i. Bourdieus teori inviterer med andre ord til, at lærere og pædagogmedhjælpere vil være indlejret i nogle sociale vilkår eller i et større og abstrakt strukturerende princip, som øver indflydelse på fx de roller, som indtages i det specialpædagogiske arbejde. Et afgørende strukturerende princip er forestillinger om forskellen på at være uddannet og ikke at være uddannet og forskellen på at være pædagog og at være lærer. Der ligger med andre ord i den større sociale sammenhæng forudgående definitioner af, hvad en lærer, en pædagog og en pædagogmedhjælper er, og hvordan de forskellige faggruppers position og arbejdsfelt kan forstås. Alle aktører må betragtes, som indlejret i dette større system af kategorier, som er med til at skabe et rum for, hvordan de kan forstå sig selv. Et væsentligt strukturerende princip er professionsdiskussioner omkring grænser og territorier for forskellige professioner. Men samtidig - og særligt med valget om at trække på Goffman - lægges vægten på, hvordan lærere og pædagogmedhjælpere forstår og fortolker deres roller og samarbejde i og om praksis.

\section{Goffman i undersøgelsens design}

E. Goffmans bog 'Jaget och maskerna - et studie i vardagslivets dramatik.' (2009) beskrives det, hvordan den observerede pædagogiske praksis kan beskrives som 'frontstage' (på scenen), og som noget andet end det, der foregår 'backstage' (bag scenen). Med en teoretisk skelnen mellem 'på' og 'bag' scenen inviteres til en opmærksomhed på både den observerede praksis og på forberedelsen af praksis og på måden, praksis forstås på. I denne undersøgelse er der foretaget observationer af forberedelsen af praksis på teammøder og lærere og pædagogmedhjælpere er blevet interviewet om deres begrundelser for, at udføre den praksis, som de udfører. Ambitionen har været at komme backstage, for at producere indsigt $\mathrm{i}$, hvordan aftaler mellem aktørerne aftales, og forskellige roller 'indøves'. Eller hvordan situationer defineres. 


\section{Situationsdefinition}

Goffman skelner mellem det at give udtryk (give expression) og det at overføre et udtryk (give off expression). Det første indeholder verbale symboler og er knyttet til den socialt acceptable rolle, og det sidste rummer aktiviteter, som andre kan opfatte som symptomatiske for enkelte individer. Goffman betegner den første som en begrænset kommunikation og den sidste som en kommunikation med en stor spændvidde. Overført til denne undersøgelse betyder det, at de forskellige faggrupper på specialskolen - lærere og pædagogmedhjælpere (og pædagoger) - umiddelbart vil referere til deres sociale/socioøkonomiske roller, som lærer og pædagogmedhjælper, men at der samtidig kan være variationer inden for rollerne, som er bestemt af individers forskellige måder at forvalte roller på. Der er ingen af disse roller, som er mere rigtige, sande og rene end andre, men pointen er, at individer indtager roller og fortolker deres egne og andres roller - og at denne nuancering må med. Her træder muligheden for flertydighed frem, som det er en ambition om at indkredse.

Det er først og fremmest den ikke verbale og situationsbundne type af kommunikation, som Goffman beskæftiger sig med. Den betegner han som ikke intentionel og bevidst (ibid. s. 14). Goffman beskriver, hvordan mennesker handler på en beregnende måde, når han eller hun overfører indtryk, for at opnå en bestemt definition af situationen (i en given praksis) og for at styre andres opfattelse af ham eller hende, men samtidig at det ikke nødvendigvis er en intentionen og bevidst form for ageren. En sådan forståelse har inspireret analysen af både fordelingen af roller og af samarbejdsrelationer. Antagelsen har været, at der kan identificeres nogle italesættelser af sociale roller, som fx 'jeg er lærer, og derfor er undervisningen mit ansvar' og 'jeg underviser ikke, det får jeg ikke løn for'. Men samtidig ligger der i den tilgang, Goffmans teori inviterer til, en antagelse om, at rollefordelingens (og senere samarbejdsrelationernes) praksis kan være en anden end den, som er italesat (i interview) og den, som kan observeres i praksis. Den rolle og de forskelle, der defineres mellem faglige positioner i interview kan anskues, som definitioner, der følger, sociale roller og definitioner af faglige positioner, som henholdsvis lærere, pædagogmedhjælper og pædagog, der refererer til professionsgrænser med professionelles specialiseringer. Men samtidig antyder Goffman med sin tilgang til studiet af socialt liv, at social interaktion rummer flere lag end den umiddelbart observerbare. Og med dette inviteres til en undersøgelse af, hvordan rollefordeling og samarbejdsrelationer kan forstås, når analysen går bagom det sagte og bagom det umiddelbart observerbare. Det at observere teammøder har været en måde at producere indsigt om netop dette niveau.

Socialt liv er altså, ifølge Goffman, struktureret af disse rolleforventninger. En væsentlig faktor i Goffmans beskrivelse af, hvordan socialt liv kan studeres er, at individer - uafhængigt af hvor aktive og passive de er - definerer situati- 
oner gennem deres respons på individer og gennem deres handlinger over for individer (ibid. s. 18). Sædvanligvis vil disse situationsdefinitioner, ifølge Goffman, være samstemte, for at der ikke i socialt liv opstår åbne modsætninger (ibid.). Den tilsyneladende harmoni i socialt liv udgøres ikke af grundige udvekslinger af holdninger og synspunkter, men kommer fra, at alle deltagere forventes at undertrykke sin oprigtige hensigt og mening. Hver enkelt må, ifølge Goffman, lægge den forståelse frem, som antages at være alment acceptabel (ibid.). Goffman antager, at deltagere i socialt liv i fællesskab bidrager til, at en enkel almen definition af situationen opretholdes. Goffman kalder denne definition for en 'præliminært fungerende enighed eller en tilfældig konsensus' (ibid., s. 18). Altså for en enighed mellem faggrupper, der fungerer som en forudgående fælles antagelse eller som en tilfældig fælles tilslutning til, hvordan rollefordeling og samarbejdet skal fungere. Denne antagelse om, at der opstår en fælleshed omkring definitionen af situationen i et fagligt fællesskab har informeret undersøgelsens design og analyser. Fokus har i produktionen af empiri og i analysen været på situationsdefinition mellem lærere, pædagogmedhjælpere (og pædagoger) i forhold til den fælles forståelse af arbejdet, som varetages og af de roller forskellige faggrupper indtager i dette arbejde. Antagelsen er, at rollefordeling og samarbejde også er bestemt af en form for fælles moralsk beslutning om, at individer har visse sociale egenskaber (positioner) og må forvente at blive mødt ud fra dem, og samtidig at andre har en forventning om, at vedkommende indtager bestemte roller, som er bestemt at position.

\section{Samarbejdet}

Goffmans teori kan bidrage med en forståelse af interaktion, hvor individer gensidigt øver indflydelse på hinandens handlinger, når de er i nærheden af hinanden. På denne måde kan teorien udsige noget om samarbejde. Med Goffman kan det fastslås, at det handlingsmønster, som viser sig, når man observerer, det er fastlagt på forhånd (ibid., s. 23) og det, som man observerer, er en rolle eller en rutine. Situationsdefinitioner kan altså knyttes til konventionelle, strukturelle termer. Det vil sige, der ligger en antagelse om, at et individ eller en aktør spiller samme rolle inden for samme publikum i forskellige situationer. Når man observerer interaktion mellem faggrupper vil det, man observerer, være sociale roller (fx lærere, pædagoger og pædagogmedhjælpere), der udspilles i interaktion. Man vil altså ikke bare studere enkeltindivider, men samspil mellem sociale roller. Derudover antages det, at det, man observerer, er forholdsvist rutinebestemt, fordi der etablerer sig en rutine i praksis, som står i forbindelse med de sociale roller og den fælles situationsdefinition, som er skabt i socialt liv (fx i et klasserum) over tid. 
Goffman bruger teaterforestillingen som metafor for principper i socialt liv og viser, hvordan mennesker spiller roller i samspil med hinanden i konkrete situationer. Han viser, hvordan mennesker præsenterer sig selv og deres aktiviteter for andre i en arbejdssituation, hvordan han styrer og kontrollerer den opfattelse, som de andre danner sig om ham, og hvad han kan og ikke kan gøre, mens han udfører sit forehavende foran andre. Den rolle, som individer spiller, er ifølge Goffman tilpasset de roller, som andre individer spiller - i fx et team på en arbejdsplads (Goffman, 1959, s. 9). Derfor vil relationen mellem lærere pædagogmedhjælpere særligt være i fokus i undersøgelsen og relationen vil blive studeret $i$ konkrete arbejdssituationer (observation af praksis), der vil blive foretaget interview af lærere og pædagogmedhjælpere sammen og endelig vil team-møder blive observeret for helt konkret at se, hvordan lærere og pædagogmedhjælpere samarbejder backstage.

En grundlæggende antagelse hos Goffman er, at individer spiller roller ud fra deres socioøkonomiske position (deres status i samfundet), som fx lærer eller pædagogmedhjælper og samtidig at andre individer, der møder fx en lærer, vil have forventninger til læreren ud fra positionen lærer. Når samarbejdet mellem lærere og pædagogmedhjælpere studeres, er det derfor ikke udelukkende konkrete individer, som studeres, men disse individers forståelse af deres egen og andres positioner. Det betyder helt konkret, at fokus i hele undersøgelsen har været på læreres forståelse af deres position i det specialpædagogiske arbejde og pædagogmedhjælpernes forståelse af deres position i det specialpædagogiske arbejde. Goffmans antagelse er, at oplysninger om individers positioner, når de træder ind i en gruppe, vil være afgørende for den 'definition af situationen', som medlemmer af fx et team kan foretage sig. Oplysninger om individers position vil gøre det muligt for andre at vide, hvad de kan forvente af ham, og hvad han forventer af dem. Og det vil gøre det muligt for medlemmer af et team fx at vide, hvordan de skal opføre sig for at få ham eller hende til at reagere på en ønskværdig måde.

Goffman definerer et team som en samling individer, der udviser en måde at samarbejde på, som har til formål at bevare en given definition af situationen. Et team er ifølge Goffman en gruppering, som opretholder en relevant definition af situationen. Et team er ikke en gruppering i relation til en social struktur eller en social organisation ( $\mathrm{fx}$ forskrifter for hvordan lærere skal agere i klasserummet), men er en gruppering i relation til en interaktion eller en serie af interaktioner. Rollen er ikke defineret som en, der fører en bestemt og foreskrevet adfærd med sig. Eller i relation til arbejdspladser foreskriver rollen ( $\mathrm{fx}$ positionen lærer) ikke bestemte funktioner i en organisation. Rollen ses derimod som en, der udtrykkes i interaktion eller i en serie af interaktioner, når medlemmer af et team eller en gruppe i relation til hinanden, opretholder en definition af situationen. Og her har roller og rolleforventninger en afgørende betydning. 
Det betyder overført til denne undersøgelse, at det der studeres, når opmærksomheden rettes mod rollefordeling og samarbejde, ikke er, hvordan fx lærere i tråd med deres rolle lever op til den forventede rolle, men snarere, hvordan en definition af situationen opretholdes i interaktion mellem forskellige faggrupper - over tid.

Og pointen er, at det, der karakteriserer et samarbejde (og fordelingen af roller), det foregår bag scenen og holdes hemmeligt for den udefrakommende. Det, som umiddelbart fremtræder frontstage karakteriseres af Goffman som et 'visuelt centrum for handling' (ibid. s. 97). En anden måde at sige det på er, at det, som blev observeret i denne undersøgelse kan karakteriseres som frontstage og som det, der umiddelbart fremtræder. Dette betegner Goffman som en del af en facade, som udgør en ramme eller en indramning. Et individs fremtræden frontstage kan betegnes som individets forsøg på at give indtryk af og på at opretholde specifikke normer (ibid.). Altså at leve op til forventninger, som individet har til sig selv og sin rolle, og til forventninger som individet antager at andre har til hans eller hendes ageren. Goffmans teori omhandler socialt liv i bred forstand, og derfor redegør han for, hvordan normer kan forstås som høflighedsnormer eller anstændighedsnormer. Anstændighedsnormer ('dekorum' er Goffmans betegnelse for dem) kan være både moralske og instrumentelle. Moralske normer henviser til anerkendte og acceptable omgangsformer, mens de instrumentelle refererer til krav, en arbejdsgiver kan stille til sine ansatte, som fx at leve op til arbejdsnormer. Goffman adskiller manerer som hører til den personlige facade, som individer opretholder, fra opførsel som henviser til sociale og kulturelle normer i en region.

I denne undersøgelse er der fokus på det sociale liv i en institutionel sammenhæng, som en specialskole er. Den norske socialantropolog Barth (2004) benytter sig af Goffmans ide om 'situationsdefinitioner'. Men i modsætning til Goffman beskæftiger han sig med interaktion i grupper i institutionelle sammenhænge. Han sammentænker relationer mellem aktører i praksis og de funktioner, som ligger i relationerne, altså måden, der interageres på (relationer i praksis) og de funktioner og roller, som individer varetager. Når relationer og funktioner sammentænkes (Barth (2004) s. 90), betyder det, at situationer i praksis defineres i relation til et samspil mellem menneskelige møder og opgaver, der skaber disse møder. Det vil sige, at den situation, der defineres i praksis, hviler på en enighed om, hvilke formål og opgaver, som ligger i møderne. Det betyder, at det, der ifølge Barth er afgørende for, hvordan et team definerer situationen også er et udtryk for en enighed om, hvordan det specialpædagogiske arbejde skal forstås, og hvilke roller (faglige roller) forskellige individer indtager i relation til det specialpædagogiske arbejde. Altså forståelsen af, hvordan faggrupper indtager forskellige roller: Hvad gør en lærer, og hvad gør en pædagogmedhjælper i specialpædagogisk arbejde på en specialskole? Hvilket an- 
svar tager de forskellige faggrupper, og, hvilke roller spiller de? Det kan ifølge Goffman og Barth ikke analyseres med udgangspunkt i de stereotype forestillinger om, hvad en lærer er, og hvad en pædagogmedhjælper er - sådan som professionerne vil definere og afgrænse sig fagpolitisk - men de må analyseres med udgangspunkt i de roller og måder at samarbejde på, som de er enige om at indtage, og som de udtrykker i interaktion i den daglige praksis. Det er netop dette niveau, som er i fokus i undersøgelsen - altså roller og samarbejdsformer i praksis.

\section{Undersøgelsens design}

Der er produceret empiri på fire måder:

- Dels er den daglige praksis i seks klasserum observeret

- Dels er en lærer og en pædagogmedhjælper fra hver af de seks team blevet interviewet

- Dels er 6 team-møder blevet observeret

- Og endelig er der foretaget fokusgruppeinterview med tredive tillidsrepræsentanter (TR'ere) for pædagogmedhjælpere på specialskoler

\section{Observation}

Samarbejdsformer samt rolle- og opgavefordeling er blevet observeret i alle team ved en dags observation af den udførte praksis i 6 klasserum. Kristiansen og Krogstrup (1999) skelner mellem forskellige måder at observere på. Strukturerede laboratorieforsøg, ustruktureret observation i naturlige omgivelser, ustrukturerede laboratorieforsøg og struktureret observation i naturlige omgivelser (ibid. s. 57-66). Det er den sidste form, som har været den valgte tilgang i observationsdelen af studiet. Observatøren har siddet på sidelinjen med en tilstræbt usynlighed og har skrevet det iagttagede ned i en notesbog. Samtidig har blikket hos observatøren været rettet stift mod en specifik lærer og en specifik pædagogmedhjælper, som på forhånd er valgt som fokuspersoner. Det er disse to personer, deres rollefordeling i fælles situationer ( $f x$ morgensamling med en gruppe elever), deres kommunikation, samt deres arbejdsfordeling (når de arbejder hver for sig), som observationerne har haft fokus på. I feltnotaterne er der skrevet det ned, som vedrører ovenstående fokus. Det er skrevet ned så tæt på de praktiske situationer, som det var muligt i situationen.

Observationsstudierne har også skabt en anden type empiri. Rollen som den ikke deltagende observatør - den usynlige flue på væggen - er helt bevidst ikke blevet holdt helt og fuldt. Observatøren har været i dialog med de medlemmer af teamene, som det var muligt og relevant at komme i dialog med. 
Særligt har opmærksomheden været rettet mod pædagogmedhjælpere, som er blevet spurgt, og som selv har fortalt, hvordan de definerer deres rolle i relation til det pædagogiske og didaktiske arbejde i klasserummet. Disse dialoger er ligeledes blevet skrevet ned og indgår som empiri i analysen.

\section{Interview}

Med en lærer og en pædagogmedhjælper fra to team blev det aftalt at foretage længerevarende interview. Samme dag, som teamets praksis blev observeret og lige efter skoledelens afslutning, blev en lærer og en pædagogmedhjælper interviewet om 1) deres begrundelser for den praktiserede specialpædagogik, 2) deres faglige selvforståelse, 3) opgavefordelingen imellem lærere, pædagoger og pædagogmedhjælpere og endelig 4) samarbejdsformer. De to første kategorier af spørgsmål fra en interviewguide (bilag 1) indeholdt dels spørgsmål omkring begrundelser for helt konkrete måder at arbejde på, som intervieweren kunne trække ind fra den observerede praksis, og dels mere generelle og situationsuafhængige spørgsmål om større pædagogiske mål og refleksioner over undervisningsformer. De to sidste kategorier af spørgsmål rettede sig i højere grad mod samarbejdet mellem forskellige faggrupper og mod samarbejdet som praksisform; hvordan aftaler man rollefordeling, kan alt aftales osv.

\section{Observation af teammøder}

Den sidste form for empiri, som er produceret på specialskolen er observation af teammøder i samtlige 6 team. Teammøderne udgør det forum, hvor pædagoger, lærere og pædagogmedhjælpere aftaler og planlægger det specialpædagogiske arbejde i de specifikke team. Mødernes varighed er 1,5 timer. Teammøderne indgår som empiri på den måde, at observatøren har skrevet referat af møderne. Dvs. dele af det, som blev sagt på møderne, og hvem der sagde det, hvad er blevet skrevet ned - under mødet. Det er disse referater som analyseres med henblik på, at undersøge rollefordeling og samarbejdsformer.

Efter hvert teammøde er de lærere og pædagogmedhjælpere, som ikke indgik i den første interviewdel blevet interviewet med henblik på spørgsmål om opgavefordelinger og samarbejdsformer. Begrundelsen herfor er, at det i observationsperioden blev tydeligt, at der er væsentlige forskelle på, hvordan de 6 team i praksis fordeler opgaver og samarbejder. Denne forskellighed i praksis blev det besluttet at repræsentere i det empiriske grundlag. Et enkelt team blev ikke interviewet efter mødet, fordi teammødet, der blev observeret, var blevet ændret til et møde med en psykolog omkring et specifikt barn. Dette møde trak ud og tiden til at foretage interview forsvandt. 


\section{Fokusgruppeinterview af TR-repræsentanter fra specialskoler}

30 tillidsrepræsentanter for pædagogmedhjælpere på specialskoler over hele landet blev $\mathrm{i}$ afslutningen af projektets empiridel interviewet. I forbindelse med en TR-konference afholdt maj 2011 i Middelfart blev en dag afsat til projekt 'Samarbejdets kunst'. Dagen bestod af et oplæg fra Lotte Hedegaard-Sørensen om projektets foreløbige teser og om 5 roller for pædagogmedhjælpere, som var blevet fremanalyseret på dette tidspunkt. På baggrund af dette oplæg blev gruppen delt i tre, og der blev foretaget fokusgruppeinterview med fokus på fordeling af rolle og måder at samarbejde på. Hvert fokusgruppeinterview blev støttet af et arbejdspapir med en beskrivelse af 5 roller og en række spørgsmål (bilag 2). Formålet med dette interview var at undersøge om foreløbige teser om roller og samarbejdsformer, som undersøgelsen på en skole var med til at danne, kunne genkendes i et bredere forum. Disse interview er blevet transskriberet og indgår som empiri i undersøgelsen. Efter fokusgruppeinterview samledes alle grupper, og det blev der fastslået, at de roller, som foreløbig havde tegnet sig i undersøgelsen, var genkendelige roller for pædagogmedhjælpere på specialskoler. 


\section{Kapitel 2. \\ Roller i specialpædagogisk arbejde}

I dette kapitel vil den observerede specialpædagogiske praksis blive formidlet særligt med fokus på pædagogmedhjælperes rolle i det specialpædagogiske arbejde. Kapitlet vil først og fremmest fungere som en beskrivelse af de observerede roller frontstage, som især pædagogmedhjælperne, indtager på den specialskole, hvor empirien er produceret til undersøgelsen.

\section{Pædagogmedhjælperes roller i det tværfaglige samarbejde}

Der er identificeret 5 roller for pædagogmedhjælpere, som træder frem i den observerede praksis. I alle klasserum indtager pædagogmedhjælpere alle roller, men nogle roller for pædagogmedhjælpere vil i nogle team være mere dominerende end i andre team. Roller for pædagogmedhjælpere er de følgende:

- At assistere undervisningen - at være med, når der undervises og med fokus på at støtte elever i at indgå - og at få undervisningen til at glide uden for mange afbrydelser.

- At forestå individuel undervisning - at vejlede og støtte enkelte eller flere elever, når de arbejder individuelt.

- At gå væk fra klasselokale eller lokale, hvor der undervises, sammen med en eller flere elever, når elever menes ikke at kunne indgå.

- At stå for pleje, hygiejne, mad m.m.

- At undervise - fx gennemgå kontaktbøger, stå for billedkunstundervisningen, gennemgå dagen, snakke om fælles, sociale arrangementer med en gruppe elever.

\section{Samarbejdsrelationer og opgavefordeling}

En række fælles forhold omkring rollefordeling og samarbejde træder frem, når undersøgelsen kommer backstage, men frontstage synes der at være små variationer (individuelle variationer) i måden rollefordelingen og samarbejdet udføres på i de forskellige team. Forskellen angår, i hvor stor udstrækning pædagogmedhjælpere og lærere opdeler aktiviteter i skoledelens praksis mellem sig og ud fra deres forskellige professionelle identiteter, som hhv. lærer og pæda- 
gogmedhjælper. I nogle klasserum og team markeres det mere tydeligt end i andre, at læreres rolle er at planlægge og udføre undervisningen, mens grænserne mellem fagpersoner er lidt mere flydende i andre klasserum. Der kan identificeres 3 forskellige former for rollefordeling i de 6 team:

- Pædagogmedhjælpere, der indgår fuldt i et arbejdsfællesskab i forpligtende samarbejde med lærere også omkring undervisningen

- Pædagogmedhjælpere, der ikke tager ansvar for undervisningsdelen, men assisterer og gør lærerens undervisning mulig

- Pædagogmedhjælpere, som er unge og indgår i arbejdsfællesskabet på en mindre forpligtende måde, idet deres ansættelse er tidsbegrænset.

\section{Undervisning er også en rolle for pædagogmedhjælper:}

I to af klasserummene ophæves grænserne i omfattende grad mellem lærere og pædagogmedhjælpere. Lærere har her det formelle ansvar for elevplaner, for statusbeskrivelser og for planlægningen af undervisningen og samarbejdet med talepædagog fx omkring udviklingen af arbejdsmaterialer, som eleverne undervises efter. Det er læreren, som skriver elevplanerne og som samarbejder med talepædagog omkring udarbejdelsen af undervisningsmaterialer, som støtter elevernes sproglige, kognitive og faglige udvikling. I interview og samtaler med pædagogmedhjælpere og lærere i disse to team fastholdes denne formelle og officielle adskillelse mellem lærere som uddannede og ansvarlige og pædagogmedhjælper som ikke uddannet og uden det formelle ansvar, men i praksis tildeles pædagogmedhjælper en meget stor rolle i dette arbejde. Pædagogmedhjælperen får og tager rum i forhold til alle de nævnte aktiviteter. I forhold til at diskutere elevplaner, i forhold til at udvikle undervisningsmaterialer og også i forhold til at organisere undervisningen i relation til det specialpædagogiske hensyn (piktogrammer, struktur osv.). Ud over dette, viser det sig i observationerne af praksis i de to klasserum, at pædagogmedhjælperen også underviser både 1:1-undervisning (en elev og en ansat) og fællesundervisning af en gruppe elever omkring en sag. Det kan være billedkunst, morgensamling og lignende aktiviteter.

Det udtrykkes i et interview fra en lærer i en af de to klasser, hvor ovenstående er dominerende, hvordan inddragelsen af pædagogmedhjælperen bliver opfattet af en lærer.

Jamen det kan være læsning blandt andet. Hvis en pædagogmedhjælper skal lære en elev at læse, så har jeg noget viden fra nogle fagbøger og så videre, noget jeg har lært på seminariet, så jeg kender 
de bedste måder at gribe det an på. Det er ikke lige det pædagogmedhjælperne har været inde omkring så meget ...

Her fastholder læreren, at hun har en teoretisk uddannelse og en viden, som hun repræsenterer, men som det udtrykkes i det følgende giver læreren samtidig stor plads til og inddrager pædagogmedhjælperen i deres fælles opgave om at undervise elever.

Jeg er nok den, der har det overordnede ansvar for, at ungerne har undervisning. At jeg så bruger pædagogmedhjælper som sparringspartner, det er jo mit valg. Jeg kunne jo godt sige til hende; du skal bare gøre sådan og sådan og sådan, og det er mig, der bestemmer det hele, men det synes jeg ikke, man får det bedste samarbejde ud af. Og jeg har det sådan, jeg kan ligeså godt bruge al den erfaring hun har, så det er sådan, jeg har gjort, og det fungerer jo. Så det er det, vi bliver ved med.

Her er to eksempler på, hvordan det at undervise henholdsvis 1:1 og fællesundervisning kan være opgaver, som pædagogmedhjælpere varetager, og som pædagogmedhjælpere $\mathrm{i}$ de to omtalte klasser varetager ofte, fordi det er en del af aftalen i teamet, at have en opgavefordeling og et samarbejde, som rummer denne rolle for pædagogmedhjælper.

\section{Undervisning 1:1:}

Pædagogmedhjælper går $i$ gang med at arbejde med en elev - de arbejder med at tælle. Pædagogmedhjælper sidder ved siden af pigen ved hendes arbejdsbord og arbejder 1:1 med hende og med en opgave, som er særligt udviklet til hende. Alle elever har en reol med en masse hylder, og på hver hylde ligger en arbejdsopgave, som er udviklet særligt til dem og $i$ samarbejde med talepædagogen. Det er forst og fremmest lærerne, som står for udviklingen af arbejdsopgaverne, men pxdagogmedhjolperen $i$ denne gruppe er med $i$ dette arbejde. Da pædagogmedhjælper har arbejdet 1:1 $i 10$ minutter med en pigen, siger hun til hende, at nu skal hun holde frikvarter, for pædagogmedhjælperen skal arbejde med en anden elev. Pædagogmedhjælper sporger pigen, om hun vil hore musik $i$ et af lokalerne ved siden af og sidde $i$ en sækkestol. Uden tydeligt signal om, at det vil hun gerne, følges hun ind $i$ et rum, ved siden af klasserummet. Pædagogmedhjælper hjælper hende med at finde $c d$, tænde for musikken og sætte sækkestolen frem. 


\section{Fællesundervisning:}

Denne gruppe er også delt $i$ to, når undervisningen gennemføres. På et tidspunkt kaldes eleverne til deres respektive grupper/lokaler, for nu skal dagen gennemgås inden morgensang klokken 09.00. Jeg observerer i et lokale, hvor en lærer og en pædagogmedhjælper skal være sammen med 4 børn denne formiddag. Børnene, lærer og pædagogmedhjælper samles omkring et fxllesbord. Pædagogmedhjælper læser børnenes kontaktbøger op for dem og snakker lidt med dem, om de aktiviteter fra dagen i går hjemme, som står beskrevet $i$ bøgerne. Inden aktiviteten går i gang aftales det, hvordan rækkefølgen af gennemgangen af kontaktbøger skal være og hvordan proceduren er ift. hvem der vælger bøger. Pædagogmedhjælper forklarer, at det er de voksne som skal bestemme rækkefølgen og som vælger, fordi Oskar dagen før var blevet rigtig sur over noget $i$ forbindelse med gennemgangen af kontaktbøger. Pædagogmedhjælper spørger $i$ løbet af samtalen læreren, om det er de voksne, som skal bestemme. Læreren siger, nej. Hun tager over eller tager ledelsen af gennemgangen af kontaktbøger. Læreren forklarer Oskar, at Laura skal vælge først, og så skal Oskar vælge til sidst. Pædagogmedhjælperen går i gang med at bede Laura om at valge. Hun vælger sin bog. Pxdagogmedhjxlper gennemgår, læser og snakker om det, der står i Lauras bog. Det er pædagogmedhjælperen, der leder hele aktiviteten, mens lareren supplerer undervejs. De sidder begge omkring bordet sammen med de 4 elever.

Rolle- og ansvarsfordelingen i disse to klasser er den, at de tre faggrupper (lærere, pædagoger og pædagogmedhjælpere) deles om de opgaver, som det specialpædagogiske arbejde kalder på. Dvs. også pleje, hygiejne, at assistere undervisning og at gå væk med (eller have særlig opmærksomhed på) et specifikt barn, som af forskellige grunde ikke kan indgå i undervisningen i klassen (fx er meget impulsstyret).

\section{Pædagogmedhjælpere underviser ikke}

I tre klasserum trækkes grænserne væsentligt skarpere op mellem pædagogmedhjælperens ansvar og rolle i samarbejdet og lærerens ansvar og rolle. I den ene klasse siges det ganske tydeligt af pædagogmedhjælper, da jeg møder op om morgenen. Hun siger: 'Jeg underviser slet ikke, for det får jeg ikke løn for'. Pædagogmedhjælperen har valgt denne rolle og det er denne rolle, som hun præsenterer sig med.

Dette valg af rolle passer godt med måden, lærerne i de to klasserum forstår og praktiserer deres rolle. De to lærere (i fokus for observationerne) tager tydeligt lederskab over aktiviteterne, og er dem, der påtager sig ansvaret for skoledelen, for undervisningen. Det er en tydeligt markeret faglig selvforståel- 
se, at det der foregår i skoletiden er karakteriseret ved skolevirksomhed - dvs. det fag-faglige er i fokus. Det betyder ikke, at der udelukkende undervises i fagfaglige fag på måder, som kan genkendes i den traditionelle folkeskole, men det betyder, at den faglige selvforståelse er karakteriseret ved, at sætte undervisningen i fag i fokus, og at det er den læreruddannede, som har ansvaret for og som udfører undervisningsaktiviteter. Andre faggrupper bliver i denne type faglig selvforståelse hos lærere positioneret eller får tildelt rollen som dem, der assisterer undervisningen i bred forstand. Dvs. som har fokus på enkeltelever i undervisningsaktiviteter (som skal beroliges), som går væk fra undervisningen med enkelte elever, som står for pleje og som assisterer eleverne, når de skal udføre de aktiviteter, som lærere sætter i gang. Det er også karakteristisk for de to lærere (i fokus her), at de begge - i modsætning til i eksemplerne overfor - er tæt på pensionsalder. Det er personer med stor personlig autoritet på baggrund af mange års erfaring $i$ og med samme arbejde.

I disse to klasserum er der et tydeligt markeret hierarki mellem faggrupper og aktiviteter. Lærerprofessionen (og de personer, som har denne status) har højeste position i hierarkiet, mens pædagoger og pædagogmedhjælpere positioneres som personer med en svagere position og dermed med ringere definitionsmagt. Hvor der i de første to eksempler tilstræbes en form for ligeværdighed i samarbejdet, er det ikke et ideal i de to team, som her er i fokus. Det betyder ikke, at stemningen er dårligt, eller at pædagoger og pædagogmedhjælpere føler sig nedvurderet. Der er en stiltiende accept af et fagligt hierarki, som ligger implicit i kulturen. Samtidig hermed eksisterer der en respektfuld form for kommunikation mellem faggrupper og en fri tone, som er karakteriseret ved humor og varme. Det skal i den forbindelse nævnes, at rollefordelingen i de to klasser, som er i fokus her, også er bestemt af elevgruppen i de to klasser. Elevgruppen i de to klasser er karakteriseret ved at være delt mellem elever med en relativt udfoldet kognitiv formåen og sprog (fx tre mongoldrenge i en gruppe) og en gruppe, som har omfattende funktionsnedsættelser. Det er elever, som sidder i kørestole, som ikke kan bevæge deres kroppe, som udelukkende kommunikerer via blikke, som skal sonde-mades, skiftes osv. eller en elev fx, som er stærkt retarderet, og som bliver meget højrystet og ikke kan indgå i nogen aktiviteter, fordi hun råber og er meget urolig. Altså, stærkt plejekrævende børn, som på ingen måder passer ind i forestillingen om 'det normale skolebarn', der sidder forholdsvist stille ved et bord og lytter eller arbejder med faglige opgaver. Når der er mange af sådanne elever i klassen, og når man samtidig har som faglig selvforståelse på skolen, at målet er at give den enkelte elev bedst mulige faglige, sociale og personlighedsmæssige læringsbetingelser, opstår der et behov for at faggrupper træder til og hjælper lærere med at kunne få skoledagen til at glide. Her er nogle eksempler på disse assisterende roller. 


\section{Assistere undervisning:}

Alle elever $i$ denne gruppe samles $i$ et lokale rundt omkring et bord. Dvs. to elever sidder i deres kørestole et stykke væk fra bordet, men dog som en del af gruppen. Begge disse elever er i omfattende funktionsnedsættelser, har ingen verbalt sprog og $i$ meget ringe omfang kropssprog fordi deres kroppe $i k-$ ke fungerer. De kommunikerer hovedsageligt gennem blikke. Læreren tager ledelsen af morgensamlingen. Hun sætter sig foran alle eleverne. Pædagogmedhjalper sætter sig foran en elev, som er meget højrøstet. Hun er 14 år, men er kognitivt aldersmæssigt svarende til halvandet år, fär jeg at vide. Hun råber højt hele tiden, skubber sig væk fra bordet og rokker frem og tilbage. Hun har ikke noget verbalt sprog. To andre elever har verbalt sprog og sidder ikke $i$ kørestol. En anden dreng sidder $i$ kørestol, men kan selv køre den frem og tilbage og har evnen til at kommunikere verbalt - om end noget usikkert. Eleverne sidder rundt omkring det samme bord, og en lærer sidder foran dem. Læreren snakker om forår. Hun viser nonverbalt, at hun bliver generet af de meget hoje lyde og den fysiske uro, som en af eleverne laver. Pædagogmedhjælperen sætter sig over til pigen og stryger hende over ryggen og på håret.

\section{At gå væk fra undervisningen med enkelte børn:}

Det er morgensamling og dagen gennemgås. Det er en særlig dag $i$ dag, fordi mange elever er fraværende. Der er 2 lærere, 1 pædagogmedhjælper og 4 elever. 'Der er ikke meget ventetid $i$ dag', siger en af lærerne. Hun siger også, at så kan de rigtig får arbejdet. Lærer fortæller eleverne - og samtidig pædagogmedhjælper - hvordan dagen er tilrettelagt. Mens hun fortæller, begynder en pige at sige, at hun ikke gider lave skolearbejde i dag. Hun vil spille computer. Lærer siger: 'Nu er det skole, så det kan du ikke-du må vente til, det er frikvarter'. Larer beder hende om at sætte sig ved fxllesbordet. Det vil hun ikke - hun bliver siddende ved sit eget bord - lidt væk fra fxllesbordet. Lxrerne lader hende sidde der lidt og går i gang med det, som de havde planlagt. De snakker om nogle maleraktiviteter, om billedudstilling, de skal holde, og om en tur, de har været på kunstmuseet Arken. Dagen - formiddagen - gennemgås igen, men nu mere med fokus på det, der skal arbejdes med, og hoordan det kommer til at foregå. De skal arbejde individuelt og har på skift en lærer til rådighed. De skal lave matematik og dansk. Pædagogmedhjælperen skal ikke være til stede. Hun skal til svømning med en af eleverne. Eleven plejer at være i sproggruppe denne formiddag, men da en anden elev ikke er $i$ skole, er det aflyst til fordel for svømning. 


\section{At stå for pleje, hygiejne, mad m.m.:}

Morgensamling skal i gang. En gruppe elever - flere $i$ kørestol - er $i$ et lille lokale sammen og sammen med en hel masse voksne. Der snakkes om, at der er særligt mange voksne den dag. Så mange, at det er lige ved, at vi går i vejen for hinanden, siger en. En larer stiller sig op ved en tavle for at gennemgå dagen. To piger i lokalet omkring et fxllesbord er meget højrøstede og rokker frem og tilbage. En af pigerne forsøger at sla sin sidekammerat. En vikar lykkes med, lige inden pigen rammer, at skubbe hende tilbage (hun sidder på en stol, der har hjul på, men ikke en kørestol). Alle ansatte i lokalet forsøger at få ro på eleverne. Det lykkes efter et stykke tid, at få alle til at være stille. Læreren gennemgår dagen. Pædagogmedhjælperen er ikke med til morgensamling. Hun er travlt beskxftiget med at fä Emilies sondemad gjort klart. Mens morgensamlingen er i gang kører pædagogmedhjælperen Emilie ind $i$ hendes kørestol og stiller hende i lokalet. Nu skal kontaktbøgerne gennemgås.

\section{Unge pædagogmedhjælpere}

I det sidste team/klasserum, hvis praksis er observeret, er pædagogmedhjælperen, som er i fokus, en ung kvinde. I bogen 'Midt imellem - fortællinger om pædagogmedhjælpernes arbejdsliv' (Bayer \& Simon Petersen (2004)) fremgår det af en spørgeskemaundersøgelse, som Langager og Robenhagen har foretaget af pædagogmedhjælpere fra dagtilbud, at der eksisterer 4 kategorier af pædagogmedhjælpere. 'De unge' (under 25 år), 'De lidt ældre unge' (25-35), 'den etablerede alder' og 'de modne' (50-60) (ibid. s. 138-139) De unge pædagogmedhjælpere er ifølge Langager og Robenhagen karakteriseret ved, at kun 3\% forventes at være ansat i sammen institution efter 3 år. Samme tendens gør sig formodentligt gældende også på specialskoleområdet. De unge pædagogmedhjælpere indtager en rolle i det specialpædagogiske arbejde, som er karakteriseret ved, at de er ansat i en afgrænset periode. I modsætning til de øvrige pædagogmedhjælpere, som er blevet observeret, er det unge mennesker (både kvinder og mænd), som ikke forventer at få tildelt en mere fast og forpligtende rolle i det arbejdsfællesskab, som etableres mellem lærere og pædagogmedhjælpere. Deltagelsen i arbejdsfællesskabet er karakteriseret ved midlertidighed. Altså, af en bevidsthed om, at relationen eller deltagelsen afbrydes inden for en overskuelig tidshorisont. Det betyder ikke, at pædagogmedhjælperne ikke er en del af arbejdsfællesskabet, men at de ikke på samme måde som de mere 'modne' pædagogmedhjælpere med længerevarende tidshorisonter forventer at have medbestemmelse og at deltage i formuleringen af mål for eleverne. Som en af de modne pædagogmedhjælpere siger i et interview: 
Jamen, jeg er nok den der type, der har svært ved at sætte mig tilbage og så sige, at jeg er pædagogmedhjælper, og jeg er kun, når de andre sætter mig i gang ikke? Det kan jeg ikke, jeg vil godt være en del af det. Det er da også derfor, jeg er så, hvad hedder sådan noget, åben i det. I forhold til mange andre herude blander jeg mig og kommer med mine ting.

De mere modne pædagogmedhjælpere (eller nogle af dem) forventer at deltage og at blive inddraget, mens samme forventning ikke kan spores hos de yngre pædagogmedhjælpere. De deltager i det specialpædagogiske arbejde og i arbejdsfællesskabet på en anden måde. Dvs. de accepterer ikke at være med til at sætte mål og at tage ansvar/lederskab for det specialpædagogiske arbejde. De gør i vidt omfang, hvad de bliver bedt om, og accepterer dermed at være til rådighed, men samtidig at blive behandlet ordentligt.

Forskellen på unge pædagogmedhjælpere og mere modne pædagogmedhjælpere er - ud over graden af deltagelse i praksisfællesskabet - det store ansvar som den modne og erfarne pædagogmedhjælper tager. Det er ansvaret for, at dagen glider, for at få alle elever til at trives, for at få alle aftaler på plads mellem unge og modne pædagogmedhjælpere, vikarer, lærere osv. i løbet af en arbejdsdag. Et sådant ansvar tager de unge pædagogmedhjælpere ikke, og de får det heller ikke tildelt. Her et feltnotat, som viser, hvordan en 'moden' pædagogmedhjælper tager ansvar og efterfølgende, hvordan hun taler om dette ansvar i et interview.

\section{Ansvarstagning:}

Det er tid til pause efter morgensamling, morgensang og endnu en morgensamling, hvor dagen er blevet gennemgået. Der kommer en vikar ind $i$ gruppen. Hun hjælper pædagogmedhjælper med alle de praktiske gøremål, som en pause involverer. Et barn skal på toilettet. Et andet barn skal hjælpes med at spise og drikke. Når barnet fra toilettet kommer tilbage, skal hun hjælpes med at fä noget at spise og drikke. I pausen går lærer hen til computer sammen med en elev, som har varet vak $i$ et stykke tid sammen med lareren. Han har brug for at være alene sammen med en voksen hele tiden og kan ikke indgå i fælles aktiviteter med de øvrige elever. Han siges at være impulsstyret og kan gøre skade på sig selv og andre. I pausen kommer han ind i lokalet og skal lave noget på computeren sammen med læreren. Efter et stykke tid spørger vikaren pædagogmedhjælperen, om hun kan gå. De snakker lige om, hoor en af pigerne er. De finder ud af, at pigen er lige uden for lokalet. Pædagogmedhjælper taler højt om, hvordan situationen er med børn, 
voksne osv. og siger: ja, hvis du lige henter (pigen som går rundt på skolen), så kan du vist godt gå..

Det er tydeligt i situationen, at pædagogmedhjælperen er den, som har det overordnede ansvar for, at alting glider. At alle elever er der, får deres mad, bliver skiftet, ikke bliver væk osv. Læreren er sammen med en meget impulsstyret elev og er ikke ansvarlig for gruppen denne formiddag. Hun har kun fokus på denne ene dreng. I interviewet siger pædagogmedhjælperen følgende om det ansvar, som hun påtager sig - og som unge pædagogmedhjælpere ikke påtager sig eller får pålagt.

Mit ansvar det er også, at klassen fungerer, at eleverne har det godt og trives, og at de er i balance. Det er, synes jeg, også er mit ansvar. Jeg skal hele tiden have overblikket over både voksne og børn. Vi deles jo om det, men nogle gange kommer jeg måske til at tage lidt mere på mig, end jeg burde gøre.

\section{Professionsidentitet i praksis}

De forskellige roller, som er beskrevet, er alle roller, der kan identificeres i praksis. Rollerne er først og fremmest identificeret ved at analysere det observationsmateriale, som er produceret fra iagttagelser af praksis. De to interview, som blev foretaget i starten af undersøgelsen, med lærere og pædagogmedhjælpere, er også inddraget.

Første del af undersøgelsen peger på, at der er forskel på, hvordan opgaver, roller og ansvar adskilles og fordeles på faggrupper. Tre typer af opgave-, ansvars- og rollefordeling er identificeret. 1) En, hvor lærere og pædagogmedhjælpere deles om alle de opgaver, som det specialpædagogiske arbejde kalder på, 2) en, hvor lærere træder frem, som dem, der først og fremmest er ansvarlige for, planlægger og udfører undervisning, og hvor pædagogmedhjælper får rollen som dem, der assisterer undervisningen, 3) og endelig en type, som er karakteriseret ved, at pædagogmedhjælperen er en yngre person, der er midlertidigt til stede, og som derfor assisterer undervisningen, og kun i begrænset omfang er inkluderet i 'kernefagligheden' omkring specialpædagogik og undervisning, men er en del af et arbejdsfællesskab i den daglige praksis. 


\section{Kapitel 3. Rollefordeling mellem lærere og pædagogmedhjælpere}

I dette kapitel vil blikket blive rettet mod rollefordelingen mellem lærere og pædagogmedhjælpere, sådan som de italesættes i interview af lærere og pædagogmedhjælpere. Kapitlet vil vise, at der på trods af forskelle i roller eksisterer en række nuancer, når undersøgelsen kommer backstage. Det er disse nuancer, som kapitlet vil formidle. Især vil der komme fokus på forholdet mellem at holde på grænserne for en professions territorium (fordi det er fagpolitisk opportunt) og at udfordre grænserne for en professions territorium (fordi praksis kalder på det).

Som det vil være fremgået i ovenstående tekst, er det antydet allerede, at der synes at være en række opgaver, der skal løses i det specialpædagogiske arbejde på specialskolen, som ikke direkte har med undervisning at gøre. En anden måde at sige det på er, at der er en række arbejdsopgaver i skoledelen på en specialskole, som må løses som en forudsætning for, at undervisningen kan gennemføres. Disse andre opgaver er indtil nu beskrevet som 'ansvaret for at få dagen til at glide', ordet 'arbejdsfællesskab' er også nævnt. Det er fremgået, at der er en lang række opgaver, som består i at håndtere børn og unges særlige behov. Behov som deres funktionsnedsættelser nødvendiggør. Det kan være plejeopgaver som hjælp til spisning, toiletbesøg og bleskift. Det kan være støtte til kørestolsbrugere, som helt konkret skal hjælpes igennem dagens mange skift: Fx overtøj, kørsel til og fra aktiviteter, og elever som skal til svømning og har brug for en person, som skal klæde af, bade, klæde på. Det kan også være støtte til enkeltelever eller til de andre elevers mulighed for at få ro til læring, som består $i$ at en person følger en elev hele dagen og foretager aktiviteter med ham eller hende (går på legepladsen, går i fællessalen og løber fx).

Elevgruppen på specialskolen har så omfattende funktionsnedsættelser, at alle ansatte (alle faggrupper) sammen som arbejdsfællesskab må løse en række pleje- og omsorgsopgaver for at få dagen til at glide og for at få skabt rum for, at der kan etableres undervisnings- og læringssituationer. Den faglige selvforståelse på skolen udtrykker eksplicit, at det specialpædagogiske arbejde på den ene side har fokus på, at eleverne skal undervises med henblik på at lære. Der 
er et opgør med en faglig selvforståelse, som først og fremmest lægger vægten på omsorg og pleje, fordi eleverne antages at have ret til at lære. Det kommer tydeligt til udtryk i de to interview, som blev foretaget i projektets start med lærere og pædagogmedhjælpere. I følgende interviewdel udtrykker en lærer det klart:

Man skal jo altid have sig målene klar, jeg vil sige, grunden til vi er her, og det er også det, der står i vores målsætning, det er, fordi vi har nogle børn, vi skal undervise. Det er det, der er det primære, det er det, der binder os sammen, voksne og børn og elever, så det står klart $\mathrm{i}$ alles bevidsthed.

Der er en fælles definition af situationen, som lyder at målet er læring, men samtidig fremgår det $\mathrm{i}$ beskrivelse af specialskolens mål, hvordan skolen formulerer mål for det specialpædagogiske arbejde, som mere og andet end det fagfaglige fokus:

Skolens målsætning er at 'give den enkelte elev bedst mulige faglige, sociale og personlighedsmæssige læringsbetingelser inden for rammerne af folkeskoleloven', 'at undervisning og fritidsaktiviteter tilrettelægges med udgangspunkt $i$ en helhedsvurdering af den enkeltes resurser og kompetencer og sigter mod at opnå mest mulig selvstændighed og nysgerrighed som grundlag for videre skolegang og en meningsfuld tilværelse', 'at tilbyde de bedste læringsbetingelser i et trygt og struktureret miljø, hvor der lægges vægt på den gode relation, hvor glæde og humor, samt et tæt forældresamarbejde, er grundlaget for trivsel og selvværd' ${ }^{10}$

Som det fremgår af målformuleringen, lægges der vægt på faglige, sociale og personlighedsmæssige læringsbetingelser, på det at tage udgangspunkt i resurser og kompetencer hos eleverne og på læringsbetingelser, som defineres som strukturerede og med vægt på den gode relation. Fokus rettes ikke udelukkende mod læring, men altså også mod betingelserne for læring. En anden måde at sige det på er, at en række andre opgaver end undervisning i fag står helt centralt i den daglige praksis og at forudsætningen for, at undervisningen kan realiseres er, at en række andre opgaver løses. Dette forhold mellem undervisningsaktiviteter og 'andre opgaver og dimensioner i det pædagogiske og didaktiske arbejde' vil blive analyseret i det efterfølgende med et fokus på pædagog-

${ }^{10}$ www.fjord-skolendk/Infoweb/Indhold/Om\%20SKolen/Om\%20Skolen.htm 
medhjælperes rolle i det tværfaglige samarbejde omkring den specialpædagogiske opgave.

\section{Grænser for profession}

Afsættet for en analyse af rollefordelingen mellem faggrupper er forestillinger omkring konstitueringen af professioner og forskelle på professioner, sådan som Fibæk Laursen redegør for det i en artikel. Han skriver:

En professions medlemmer skal kunne noget særligt for at opretholde deres status som professionelle. En sådan specifik sagkunskab er sammen med et 'territorium' det mest basale for en profession. Dens medlemmer må kunne noget bestemt, som folk, der ikke er medlemmer af professionen, ikke kan (Fibæk Laursen, 2004, s. 5).

Fibæk Laursen slår det fast, som er en klassisk betegnelse for diskussioner af faggrænser mellem forskellige faggrupper, at bestemte arbejdsopgaver er anerkendte som særlige for specifikke professioner. Lærerprofessionens grænser beskrives som stort set sammenfaldende med folkeskolens og er altså tæt forbundet til folkeskolen som institution og denne institutions formål; nemlig undervisning og læring. Det betyder, ifølge Fibæk Laursen, ikke, at lærerprofessionens grænser ikke anfægtes. 'Det er nærmest en normaltilstand for en profession, at den ligger i nabostridigheder langs grænserne for sit territorium' (ibid.), og også lærerprofessionen må arbejde på at opretholde grænserne. En klassisk kamp for lærerprofessionen nævnes at være kampen med pædagogerne omkring indskolingen.

Lejf Moos redegør i en tekst 'Relationsprofessioner' (2004) for det, som titlen antyder, nemlig hvordan lærer- og pædagogprofessionen kan beskrives som relationsprofessioner (ibid. s. 251). Ifølge Moos kan relationsprofessioner ikke adskilles fra en offentlig forvaltningsfunktion, idet de er dybt integreret i den offentlige sektor. Moos peger på en række dilemmaer i forhold til relationsprofessionernes status i samfundet, som antages at være under påvirkning af politiske tendenser i den offentlige sektor. Han skriver, at der er en tydelig modsætning i begrebet 'offentlige professioner'.

Professioner signalerer, at man taler om en faggruppe, der specialiserer sig for at kunne klare sine opgaver bedst muligt, og som samtidig beskytter sit arbejdsfelt mod ikke professionelles indtrængen'. De offentlige arbejdsgivere udtrykker tydeligt, at de har brug for specialiseringen, dygtiggørelsen og på samme tid fleksibilitet og samarbejde hen over professionsgrænser (ibid. s. 251). 
Citatet indfanger meget præcist, hvordan situationen kan beskrives på specialskolen med hensyn til arbejdets karakter og den måde, der kaldes på fleksibilitet og samarbejde hen over professionsgrænser. I nogle klasserum på specialskolen synes dette vilkår at være integreret i den mere intenderede faglige selvforståelse. I den første type arbejder lærere, pædagogmedhjælpere og pædagoger sammen om løsningen af de forskellige arbejdsopgaver. Grænserne mellem og forskellene på faggruppernes uddannelsesniveau og faglige perspektiv eksisterer og indgår i samarbejdet, men grænserne er flydende. I den anden type holdes grænserne mere mellem en lærerfaglighed og en pædagogmedhjælperfaglighed. Men samtidig viser observationer, at det er ganske vanskeligt i praksis at opretholde grænserne. Arbejdet og eleverne vil løbende udfordre dem. Netop denne empiriske indsigt vil danne afsæt for indeværende kapitel.

Når dette kapitel går i dybden med forholdet mellem professionelle identiteter og rollefordelingen mellem professionelle - her lærere og pædagogmedhjælpere - tages der afsæt i den observerede praksis i klasserummene, sådan som de er redegjort for. Men først og fremmest trækkes der på analysen af empiri fra interview af lærere og pædagogmedhjælpere, hvor de taler om professionelle identiteter og roller.

\subsection{Rollefordeling i praksis}

I interviewene blev lærere og pædagogmedhjælpere spurgt om, hvordan de selv forstår egen rolle som hhv. lærere og pædagogmedhjælpere, og hvordan de forstår hhv. lærerens rolle og pædagogmedhjælperens rolle. Analysen er foretaget på den måde, at samtlige udsagn om læreres rolle (fra lærere selv og fra pædagogmedhjælpere) og samtlige udsagn om pædagogmedhjælperes rolle (fra pædagogmedhjælpere selv og fra lærere) er blevet samlet og skrevet sammen til en fælles fortælling om måden læreres og pædagogmedhjælperes roller i det specialpædagogiske arbejde bliver opfattet af dem, som selv indtager dem. I lyset af Goffmans og Barths teori er det en afgørende brik i forståelsen af, hvordan en fælles enighed - i de forskellige team - om, hvordan roller forstås, skabes backstage, og hvordan roller indtages i relation til positioner, og måden aktører i team forstår hinandens positioner og forvalter egne roller og positioner.

\section{Specialpædagogik imellem teori og praksis}

Som nævnt tidligere tyder noget på, at det er meget vanskeligt - i praksis - at opretholde adskillelsen mellem forskellige faggruppers roller, fordi det specialpædagogiske arbejde består i meget andet end at undervise i fag, og fordi det at undervise også involverer en relationel kompetence eller en evne til at skabe 
forudsætninger for, at undervisningen kan udføres. I et pædagogisk feltstudie af specialpædagogisk praksis i forskellige læringsmiljøer (Hedegaard-Sørensen 2010a) fremanalyseres det - parallelt hermed - hvordan det pædagogiske og didaktiske arbejde kalder på en integration af omsorg/hygiejne, relation og didaktik (undervisning), og at der er et stykke vej fra 'et symbolsk mesterskab' til et 'praktisk mesterskab', sådan som den franske socialantropolog Pierre Bourdieu definerer adskillelsen mellem det sprogligt at give udtryk for, hvad man ved (og begrunde efter teorier og regler) og at mestre noget praktisk. Det sidste henviser til, at det at håndtere konkrete pædagogiske og didaktiske situationer involverer en praktisk kundskab, som ikke vejledes af teorier, men af evnen til at handle. I det omtalte pædagogiske feltstudie og en artikel, som bygger herpå (Hedegaard-Sørensen (2010a) og Hedegaard-Sørensen og Tetler (2011)) defineres denne praksiskundskab som situeret professionalisme. Dvs. en måde at være professionel på, der ikke udelukkende refererer til teoretisk viden, men som også refererer til praktisk viden.

En sådan forståelse af, hvordan professionalisme kan forstås som noget, der er situeret i praksis, udfordrer forestillingen om, at det udelukkende er de, der er uddannet til at varetage det specialpædagogiske arbejde, som har en væsentlig rolle i det specialpædagogiske arbejde. Men samtidig betyder det ikke, at teoretisk viden ingen afgørende betydning har for kvaliteten af det udførte pædagogiske arbejde. Mere om det senere. I forhold til indeværende undersøgelse betyder det, at den pædagogiske og didaktiske praksis i det specialpædagogiske område også - og rummer et praktisk mesterskab, som pædagogmedhjælpere indgår i på linje med andre ansatte i praksisfællesskaberne på specialskolen. Og dette praktiske mesterskab har en afgørende betydning for, at de forskellige faggrupper (her først og fremmest pædagogmedhjælpere og lærere) sammen realiserer et mål om elevers læring. Analysen som formidles i det efterfølgende viser netop, hvordan denne empiriske og teoretiske indsigt fra andre studier kan indgå som teoretisk forklaring på empiriske fund i dette studium her med fokus på roller og samarbejdsformer.

\section{Undervisning og pædagogik er hinandens forudsætninger}

Der har i en årrække i debatten omkring lærerprofessionen været fokus på både det faglige, sociale og det personlige formål. Der synes at være et ideal i læreres selvforstålse og i den teoretiske diskussion om læring (se Illeris, 2006) om, at disse elementer må tænkes sammen, når en forståelse af skolers (også specialskolers) mål for eleverne, og når læreres faglige selvforståelse defineres. Illeris definerer læring som en samspilsproces mellem individet og dets omgivelser, hvor læringen tilegnes og bearbejdes i samspillet og i relation til tidligere læring (ibid., s. 43). Læringen betragtes som en social proces, hvor handlinger, følelser, 
opmærksomhed, tænkning og omgivelser spiller sammen. Det betyder, at læring betragtes som en både kognitiv, psyko-dynamisk og en social proces (ibid., s. 181), hvorfor undervisningen og mål for elever må tænkes bredere end blot individers tilegnelse af fag-fagligt indhold.

I forskellige pædagogiske feltstudier (Hedegaard-Sørensen, (2010a) og Hedegaard-Sørensen (2010b) fremgår det, at idealet om et bredere læringsbegreb ikke realiseres i den specialpædagogiske praksis. Når lærere interviewes om deres arbejde og begrunder de valgte praktiske tilrettelæggelser, viser det sig, at stort set samtlige lærere i de to undersøgelser lægger vægt på et bredt undervisningsideal. Men når læreres praksis observeres, synes der at opstå en konflikt mellem de forskellige formål. Der synes at være en tendens i praksis til, at hovedvægten hos lærere lægges på undervisning, og at 'alt det andet' synes at være en smule i vejen for gennemførelsen af den. Eller formuleret på en anden måde synes der at være et implicit ideal om, at personlige og sociale dimensioner ikke bør vise sig, når der undervises.

Store dele af den specialpædagogiske kompensatoriske indsats (fx Teacch programmets metoder), som lærere i specialpædagogiske sammenhænge trækker på, kan forklares som en metode til at få de forstyrrende, uroskabende og konfliktfylde elementer i undervisningen reduceret. Metoden tilbyder struktureringer, visualiseringer og piktogrammer, som er tænkt som en imødekommelse af elevernes behov for struktur. På den ene side kan disse metoder begrundes med, at eleverne har brug for dem som en konsekvens af deres funktionsnedsættelser og deres indlæringsvanskeligheder. Men - og det har været en pointe i de omtalte feltstudier - de kompensatoriske metoder kan også betragtes som metoder til at skabe elever, der lever op til et undervisningsideal om, at hovedaktiviteten i skolen er fag-faglig læring. Elevernes rolle i den fag-faglige læring er at være motiverede og parate til at indgå i undervisningssituationer, hvor de engagerer sig i fag-faglig læring. Et succeskriterium synes at være for lærere, at eleverne sidder stille ved deres afskærmede arbejdsborde, deres borde i klassen eller omkring fællesbordet og at de loyalt tilpasser sig et (tilsyneladende) dominerende undervisningsideal (i praksis) om, at læreren gennemgår det faglige stof, mens eleverne lytter og spørger ind, og at eleverne derefter alene eller sammen arbejder med stoffet.

Det viser sig imidlertid i de pædagogiske feltstudier af specialpædagogiske læringsmiljøer, at de metoder, som specialpædagogisk arbejde trækker på visualiseringer, struktureringer osv. - ikke helt lever op til hensigten. I de læringsmiljøer, hvor feltstudierne er foretaget synes uro, konflikt og afbrydelser at være en gennemgående tendens. Eleverne synes ikke at reagere som forventet, på trods af, at den specialpædagogiske kompensatoriske indsats fra fx Teacchprogrammet har en omfattende rolle i praksis. En anden måde at sige det på er, at de specialpædagogiske kompensatoriske programmer ikke kan stå alene i 
håndteringen af de udfordringer og den kompleksitet, som specialpædagogisk arbejde involverer.

I studier af specialpædagogiske læringsmiljøer (særligt HedegaardSørensen (2010a)) problematiseres den kompensatoriske specialpædagogiske tænkning. Og især problematiseres det, at der ligger en forestilling til grund for denne tænkning om professionalisme, som ikke medtænker den specialpædagogiske praksis - og kompleksiteten der. Den specialiserede viden udgør en meget omfattende del af den faglige selvforståelse for det specialpædagogiske arbejde og denne viden tilbydes lærere via kurser og konsulentbistand. Antagelsen er, at lærere (og andre faggrupper) kan overføre denne viden til deres praksis. Det, som ikke medinddrages i diskussionen er, hvordan samspillet er mellem den praksis, som udføres og de kompensatoriske metoder som foreslås. Eller om den specialpædagogiske praksis og den praktiske og situerede kundskab, som finder sted der er forenelig med mere enstrengede og målrettede kompensatoriske metoder og 'løsninger'. Specialpædagogisk praksis består af en række pædagogiske situationer og didaktiske situationer, hvor lærere (og andre faggrupper) er i samspil og relation til en eller flere elever i den kontekst, som et klasserum udgør. Som det vil fremgå udgøres disse situationer af en række andre elementer end undervisning og specialpædagogiske kompensatoriske metoder.

Antagelsen er, at der er to typer af kundskab og to typer af professionalisme i gang på samme tid og at de ikke umiddelbart lader sig forene. Dermed opstår der en splittelse hos praktikere (lærere, pædagoger og pædagogmedhjælpere) i deres praksis mellem den praktiske undervisning og den specialiserede viden. De to dele er ikke velintegrerede. Også fordi de fagpersoner, som arbejder i praksis kun i meget ringe omfang bliver vejledt i, hvordan konkrete undervisningssituationer bedst kan håndteres også i relation til elevernes funktionsnedsættelser. Den negative utilsigtede konsekvens er, at undervisningen og undervisningssituationer ikke synes at være tilpasset elevernes vanskeligheder. Undervisningen undslipper sig en professionalisering i det hele taget og kommer til at leve sit tavse og ureflekterede liv - ved siden af en professionalisering, som består i at overføre specialiseret viden, specialiserede programmer, metoder og koncepter (Hedegaard-Sørensen (2010a) og Hedegaard-Sørensen (2011)).

Det er et særligt karakteristikum for nærværende specialskole, at eleverne er i omfattende indlæringsvanskeligheder og har omfattende funktionsnedsættelser. Et stort antal elever på skolen har ikke noget verbalt sprog og deres intellektuelle niveau er for nogens vedkommende vurderet til at være 1,5 år. På en skole, som denne og med en elevgruppe, som denne bliver det ganske vanskeligt at opretholde forestillingen om undervisning, læring og det fag-faglige 
fokus på en traditionel måde. Eleverne kalder i den grad på, at der findes andre og nye veje.

\section{Specialiseret viden i den faglige kultur}

På specialskolen, hvor undersøgelsen er foregået, synes der i omfattende grad at være en integration af specialiseret viden og undervisning. Den splittelse, som før er omtalt mellem specialiseret viden og undervisning, synes ikke at være så udtalt på denne skole. Lærere, pædagoger og pædagogmedhjælpere trækker på en række metoder - pecs ${ }^{11}$, social stories, piktogrammer, visualiseringer osv. og kombinerer dem med de undervisningsaktiviteter, som de i øvrigt udfører. Morgensamling består af en gennemgang af dagen ud fra piktogrammer og visualiseringer, alle elevers skema gennemgås tydeligt, der er kommunikationsstøttende billeder, som bringes i anvendelse i alle aktiviteter, undervisningsmaterialer er tilrettelagt $\mathrm{ud}$ fra elevernes individuelle forudsætninger og kan i stort omfang karakteriseres som støtte til kommunikation, selvstændighed, selvhjulpenhed, funktionsevnetræning osv. Fysioterapeuter og talepædagoger tager ofte elever ud af klasserummet og laver individuel træning med dem, lærere og pædagogmedhjælpere tager elever ud af undervisningen og laver Pecs træning og social stories med individuelle elever. I alle team tilrettelægges undervisningen sådan at fællesundervisning kun udgør en meget lille del af undervisningsaktiviteterne. Eleverne deles ind i to grupper og de ansatte, som er tilknyttet 4-5 elever i hver gruppe organiserer undervisningen sådan, at eleverne undervises individuelt i de individuelt tilrettelagte undervisningsmaterialer. Den specialiserede viden indgår altså i stort omfang i den måde undervisningen tænkes og praktiseres på. Når konsulenter vejleder lærere, pædagoger og pædagogmedhjælpere, er det med henblik på at vejlede i, hvordan undervisningsmaterialer og undervisningssituationer bedst tilrettelægges for individuelle elever.

\section{En udvidet forståelse af læring}

En anden konsekvens, der tages af elevernes omfattende funktionsnedsættelser er, at den klassiske fag-faglige undervisning - også når den ikke integreres med specialpædagogiske, kompensatoriske metoder - tænkes specifikt i relation til elevernes nedsatte funktionsevner.

Når man underviser i dansk fx er det typisk en undervisning, der tager udgangspunkt i kommunikationstræning og begrebsforståelse med undervisningsmetoder, som er helt specifikt tilrettelagt ud fra elevernes funktionsnedsættelse. Når man underviser i billedkunst består undervisningen i, at eleverne

${ }^{11}$ Pecs (Picture Exchange Communication System) er et kommunikationsstøttende redskab, som er udviklet i Amerika, og som anvendes til elever med svag eller ingen verbal kommunikation. 
maler med to farver på et lærred. Undervisningen vil typisk foregå sådan, at en lærer står med ansvaret for undervisningsaktiviteten, mens adskillelige andre fagpersoner (lærere, pædagoger og pædagogmedhjælpere) assisterer de enkelte elever i forhold til en række praktiske opgaver omkring forklæder, hente lærred, støtte eleven $i$ at male ved at holde på penslen osv. Når der undervises i matematik kan det fx bestå $\mathrm{i}$, at nogle elever laver en købmandsbutik og sælger varer til de andre elever. Læringen ligger i at give penge tilbage - det er vel at mærke for elever, der har sprog og en forholdsvis stor kognitiv formåen. Nogle elever arbejder med læsebøger og matematikopgaver og med computerprogrammer, der har som sigte at øge elevernes læse- og regnefærdigheder. De er alle tilpasset elevernes funktionsniveau. Tavleundervisning og fælles dialog omkring et fagligt stof er stort set fraværende på skolen.

Som det vil fremgå af de efterfølgende analyser, kalder det specialpædagogiske arbejdes karakter på et tværfagligt samarbejde mellem forskellige faggrupper omkring løsningen af en opgave, som ikke udelukkende består i at undervise elever i fag. Elevernes funktionsnedsættelser forudsætter, at læringsmål $i$ vidt omfang tager udgangspunkt $i$, at elevernes funktionsevner er nedsatte. Hiim og Hippe (2006) indkredser en relationel forstålse af didaktik, som teoretisk kan indfange den didaktiske kompetence, som består i at lærere, pædagoger og pædagogmedhjælpere $i$ et fagligt fællesskab må balancere mellem hensynet til undervisning i fag og til det vilkår, at elevernes forudsætninger må indtænkes, når undervisningen planlægges og udføres. Altså at undervisningens indhold, samt måden at undervise på, tilpasses eller relateres til elevernes forudsætninger. Hiim og Hippes didaktiske model er ikke tænkt ind i det specialpædagogiske praksisfelt, men kan fint støtte en faglig selvforståelse, som kan udvikles og raffineres i det specialpædagogiske område, og som kan begrunde nytten af tværfagligt samarbejde. Hiim og Hippes relationelle didaktik har ikke bare fokus på uddannelsers mål og indhold, men også på læreprocesser, undervisningsmetoder og læringsaktiviteter (Hiim og Hippe, 2006, s. 15).

Deres didaktiske model har seks komponenter, som de beskriver som didaktiske hovedkategorier, der står i forbindelse med hinanden. Kategorierne er: "Lærerforudsætninger, rammefaktorer, mål, indhold, læreprocessen og vurdering" (Hiim og Hippe 2006, s. 17). Målet med modellen for didaktisk relationstænkning er, at den kan systematisere læreres planlægning, gennemførelse, vurdering og kritiske analyser af undervisning og læring. Modellen for didaktisk relationstænkning indtænker elevers forudsætninger for at lære, konteksten for undervisningen (som fx klasserum eller grupperum, tid til disposition, hjælpemidler osv.), målene for undervisningen (dvs. hvad er det målet, at eleverne skal lære på kort og langt sigt), fagindholdet (som hænger sammen med målene og henviser til det, som undervisningen handler om), læreprocessen (og med det spørgsmål 'Hvad skal eleven gøre?', 'Hvad skal læreren gøre?', 'Hvor- 
dan motiverer læreren eleverne?'), og endelig henviser vurderingen til lærerens vurderinger af undervisningsprocessen i forhold til mål for læringsaktiviteter og i forhold til elevernes læring.

Det, som Hiim og Hippes model tilbyder den specialpædagogiske faglighed, er en didaktisk tænkning, som både inddrager elevernes forudsætninger for læreprocesser og samtidig fastholder et blik på kontekst, praksis og på konkrete undervisningssituationer. Det er en faglighed, som også lærerne på indeværende skole med fordel kunne støtte sig på og det er en faglighed, som henviser til, at der er behov for, i det praktiske arbejde, at forstå, hvordan undervisning og andre pædagogiske aktiviteter kan professionaliseres. Og det er en faglighed, som lærerne i et vist omfang praktiserer efter på den specialskole, som er i fokus for undersøgelsen.

Med afsæt i en teoretisk ramme for, hvordan undervisning og læring kan forstås bredere, vil fokus komme på de empiriske indsigter fra indeværende studie, som netop viser, hvordan det tværfaglige samarbejde ser ud i praksis, og hvordan det knytter sig til ovenstående teoretiske ramme, der forklarer arbejdets karakter med en relationel didaktisk teori, der tager udgangspunkt i elevernes forudsætninger og i lærerprocesser.

\subsection{Rollefordelingens praksis}

Herfra formidles det, hvordan lærere i interview taler om deres egen rolle i det specialpædagogiske arbejde. Det vil fremgå heraf, hvordan det specialpædagogiske arbejde på skolen - af lærere - bliver forstået ud fra en forudsætning om, at det ikke alene er en lærerfaglighed med et entydigt fokus på undervisning og/eller på en kompensatorisk specialpædagogisk tænkning, som dominerer den faglige selvforståelse. Derefter vil pædagogmedhjælpernes rolle blive fremanalyseret. Der synes at være en sammenhæng mellem den måde lærere forstår og praktiserer specialpædagogik på en 'praktisk' og 'realistisk' måde og den store rolle, som pædagogmedhjælpere får i håndteringen af pædagogiske og didaktiske situationer. Mere om det i efterfølgende dele af analysen.

\section{Læreres definition af egen rolle}

Samtlige interviewede (6) lærere fra specialskolen bevæger sig i et kontinuum, når de beskriver deres rolle. På den ene side markerer de, at de har ansvaret for undervisningens planlægning og udførelse med følgende formuleringer:

- Det er jo primært lærernes opgave at lave de arbejdsopgaver som passer til børnene

- Jeg er meget mere faglig end pædagogmedhjælpere og pædagoger 
- Jeg er den, der har det overordnede ansvar for, at ungerne har undervisning, og jeg kan det der tekniske omkring undervisning - didaktik altså

- Jeg skal stå til ansvar for folkeskolens formålsparagraf og over for forældre og over for min ledelse og over for mine kollegaer og eleverne

- Jeg tænker over, at jeg skal opfylde de mål vi har, så jeg kan dokumentere, at vi når det, vi skal ud fra mål i folkeskoleloven

- Det er mig, der har det sidste ord at skulle have sagt, hvad angår undervisningen

- Jeg skriver undervisningsplaner og holder møde med forældre, og når jeg planlægger i forhold til elever - sammen med kollegaer - prøver jeg at tænke de planer ind; det kan jeg have det lidt nemmere med

- Jeg tænker mere i undervisningsplaner, folkeskolelov og fælles mål, selvom vi laver dem sammen.

Samtidig med, at den socialt producerede lærerrolle - den sociale rolle - er en rolle, som lærere påtager sig, formuleres det af samtlige lærere, at de har brug for særligt pædagogmedhjælpere, men også pædagoger, i undervisningsdelen for at kunne få realiseret deres mål om at lære elever noget. En lærer begrunder det med, at det at sætte et fokus på læring - elevernes ret til læring - er en væsentligt uddannelsespolitisk sejr, som der må værnes om. At lærere skal have ansvaret for undervisningen, og at der skal undervises i relation til folkeskoleloven, begrundes med elevernes ret til læring, og udgør et argument for lærerne for, at pædagoger og pædagogmedhjælpere ikke skal overtage det fulde ansvaret for det specialpædagogiske arbejde. Her er hendes formulering:

- Jeg kan jo huske helt tilbage fra da åndssvageforsorgen skulle udlægges. Der hvor det kom i fokus, at udviklingshæmmede skal undervises af lærere. Jeg synes ikke pædagoger skal erstatte undervisningen. Eleverne har ret til at lære noget.

Samtidig med denne opmærksomhed anerkender lærerne, at de har brug for pædagoger og pædagogmedhjælpere (især) i undervisningen for at kunne realisere deres mål. I mange af klasserummene organiseres undervisningen sådan, at eleverne undervises 1:1. Det betyder helt praktisk, at den ene eller de to lærere, som er til stede sammen med op mod ti elever kun kan rette opmærksomheden mod to elever og er afhængig af, at nogle tager ansvaret for de resterende. Og at disse nogle, først og fremmest pædagogmedhjælpere, også påtager sig et ansvar for undervisningen og underviser. Dvs. på den ene side trækker lærerne en grænse omkring deres faglighed, som består i, at de formelt set står med ansvaret for undervisningen, men på den anden side tillægger de samar- 
bejdet med pædagogmedhjælpere og pædagoger stor betydning i forhold til at få mål om læring opfyldt for eleverne.

En lærer formulerer direkte, at der i praksis, ikke kan ses nogle forskelle på de roller, som de forskellige faggrupper varetager.

- I praksis er det nok svært at se forskel på os

Nogle lærere argumenterer for, når de beskriver egen rolle på specialskolen, at de ikke synes, det er meningsfuldt at afgrænse egen rolle fra pædagogers rolle. De siger:

- Som lærer på en specialskole er jeg også en slags pædagog. Jeg tænker mere i relationer. Vi kan ikke lære dem noget, hvis vi ikke har en god relation. Så på den måde er jeg nok lidt pædagogagtig

- Den faglige udvikling er en fælles opgave og interesse for alle. Der er mange andre ting end de rent fag-faglige på en specialskole - der er også det sociale

- Jeg ved jo, at jeg skal sige, at jeg er lærer på en specialskole, men det fagfaglige felt, det er jo udvidet med en masse andre ting.

Konkluderende beskriver lærerne deres rolle og mål med deres arbejde, som dem, der underviser elever, så de lærer mest muligt. De anerkender samtidig, at det at være lærer på en specialskole også involverer et pædagogisk fokus og en pædagogisk faglig selvforståelse ind i en lærerfaglighed, og at der er brug for pædagoger og pædagogmedhjælpere i forhold til indfrielse af målet om læring.

\section{Specialpædagogik på specialskolen med elever i omfattende vanskeligheder}

Som det fremgår anerkendes det hos lærere og pædagogmedhjælpere, at det at undervise på en specialskole involverer en bred tilgang til læring. Det fremgår tydeligt - af især lærernes perspektiv - at læreren har en faglig selvforståelse omkring det specialpædagogiske arbejder, der involverer en række andre dimensioner end det at undervise. De snakker om 'alle de andre ting', om 'relationer' og om 'det sociale'. Derudover siges det, at det i praksis 'kan være svært at se forskel på os' og med det menes på pædagogmedhjælpere og lærere. Der synes at være en overensstemmelse mellem den faglige selvforståelse, som lærere har og den praksis, de er situeret $i$.

Dette står i kontrast til de øvrige klasserum, som de nævnte pædagogiske feltstudier har observeret. Det er en tese, at denne mere 'realistiske' og 'praktiske' faglige selvforståelse også hænger sammen med, at elevgruppen rummer elever med omfattende funktionsnedsættelser. Eleverne kan ikke 'blot' beskri- 
ves ud fra deres diagnose, men må beskrives ud fra deres generelle funktionsevne, som er nedsat i omfattende grad. Konsekvensen, der tages af denne elevgruppe, kan deles $\mathrm{i}$ to dele. På den ene side indgår den specialiserede viden med stor vægt $\mathrm{i}$ undervisningen og i den samlede faglige kultur i klasserne, og på den anden side tænkes undervisning med en bredere forståelse af læring.

\section{Pædagogmedhjælpernes roller}

Pædagogmedhjælpere på specialskolen er først og fremmest placeret i en arbejdssituation, som i modsætning til pædagogernes placering, har med undervisningsdelen at gøre. Pædagogmedhjælpere arbejder med skoledelen på specialskolen, hvor pædagoger kun i meget ringe omfang sætter mål og er til stede. Analysen af pædagogmedhjælperes opfattelse af lærernes roller i undervisningen viser da også, at pædagogmedhjælpere ikke udfordrer læreres forestilling om, at det er undervisning og læring, som er i fokus. Måske derfor er det forholdsvist uproblematisk for pædagogmedhjælpere og lærere at samarbejde. I modsætning til pædagogerne sætter pædagogmedhjælperne ikke andre mål, men støtter de mål, som lærere - ofte i samarbejde med pædagogmedhjælpere sætter. Her analysen af pædagogmedhjælpernes syn på læreres rolle:

\section{Pædagogmedhjælperes definition af læreres rolle}

Pædagogmedhjælperne på specialskolen er alle - i interview - anerkendende over for læreres særlige professionelle kompetence, som de har erhvervet sig via deres uddannelse som lærere. Her nogle formuleringer, som viser dette:

- Jeg tager også ansvar, men i sidste ende er det lærernes

- Inden lærer var på barsel, gik hun ind og sagde: 'Det kunne måske være, du kan få fat i de her bøger til ham'. Der gik hun ind med sin faglighed og kendskab til bøger, og det ville jeg ikke selv have kendskab til

- Der er nogle ting, rent fagligt, hvor jeg godt kan mærke, at det har de sgu læst til

- Hun er jo en faglærer, så hun har jo sine kompetencer, blandt andet også et andet sted, fordi hun har mange kompetencer. Det er ikke kun den, hun er, men også hendes faglighed og de mål, hun skal nå - det er hende, der har hovedansvaret kan man sige. Hun skal give videre til mig, og så skal jeg bakke op om det.

Som det fremgår, mangler pædagogmedhjælperne ikke anerkendelse af lærernes særlige kompetence, faglighed og ansvar. De anerkender, at målet med elevernes tid på specialskolen er at lære - at blive bedre til at kommunikere fx. 
Pædagogmedhjælpere anerkender med andre ord, at hvis målet om læring skal indfris - og det specialpædagogiske arbejde ikke skal reduceres til omsorg og pleje - så er der brug for den kompetence, som lærere har.

\section{Pædagogmedhjælperes syn på egen rolle og læreres syn på pædagogmed- hjælperes rolle}

Fælles for pædagogmedhjælpere og lærere er, at de, som omtalt, har opfattelse af det specialpædagogiske arbejde, som et arbejde, der involverer undervisning, men også en række andre komponenter. Og det er i relation til disse andre komponenter, at pædagogmedhjælperes rolle træder frem.

Det at sætte et fælles mål om, at eleverne skal gå i skole og lære så meget som muligt under forudsætning af deres omfattende funktionsnedsættelser betyder, at lærere og pædagogmedhjælpere er fælles om at samarbejde omkring indfrielsen af dette mål. Det er læreres og pædagogmedhjælperes fælles ansvar at udvikle en faglig kultur og en måde at få praksisfællesskabet til at fungere på, som gør det muligt, at eleverne lærer på trods af deres omfattende funktionsnedsættelser. Her de empiriske fund omkring denne problematik:

\section{Læreres definition af pædagogmedhjælperes rolle}

Undersøgelsen har ikke fokuseret specifikt på pædagogernes rolle. Pædagogerne har været med til teammøder og indgår med få timer i skoledelen på SFO, og i den forstand indgår de, men det er først og fremmest pædagogmedhjælpere, der indgår som faggruppe i skolens virksomhed. Når lærerne formulerer, at der er brug for 'det pædagogiske', 'det relationelle' og 'det sociale' er det altså i vidt omfang i relation til det arbejde, som pædagogmedhjælperne varetager i skoledelen.

Antagelsen er, at dette er sammenhængende med den organisatoriske deling mellem skoletid (med få pædagogtimer) og SFO-tid (med udelukkende pædagogtimer og få pædagogmedhjælpertimer). Det er en gennemgående holdning hos lærere, at det er nemmere at samarbejde med pædagogmedhjælpere end med pædagoger. Pædagogmedhjælpere og lærere orienterer sig fælles efter at undervisningen skal lykkes bedre, mens pædagoger bliver iagttaget som en faggruppe med en særlig faglighed, der ikke umiddelbart er forenelig med en lærerfaglighed. De to faggrupper sætter, som det udtales af lærerne, forskellige mål:

- Altså det der er min primære opgave med mål, det er jo at sætte dem faglige, hvor pædagogernes er mere sådan personligt og udviklingsmæssigt. Så der er forskellen jo. 
- Hvis vi står om morgenen, og der ikke er nogen lærer, så er det faktisk også pædagogmedhjælperen der lægger skema og tager dem; også selvom der er en pædagog.

Lærerne taler om pædagogmedhjælpernes rolle og bidrag ind i deres lærerfaglighed på følgende måde:

- Jeg bruger pædagogmedhjælperen som sparringspartner og trækker på hendes erfaring. Det er jo mit valg. Jeg kunne jo godt sige til hende: 'Du skal bare gøre sådan og sådan og sådan, og det er mig der bestemmer det hele', men det synes jeg ikke, man får det bedste samarbejde ud af

- Vi er glade for, at pædagogmedhjælpere tager ansvar og har ideer; ideer til at løse problemstillinger

- Hun er god til at fange eleverne

- Vi laver en plan, og så kan pædagogmedhjælperen gå ind og undervise

- Jeg har en tryghed for, at det praktiske og omsorgsopgaver bliver udført til punkt og prikke, for hun er meget arbejdsom og ansvarsfuld

- Den faglige udvikling er en fælles opgave og interesse for alle - der er mange andre ting end det fag-faglige

- Når vi udvikler arbejdsopgaver kommer pædagogmedhjælperen med input fra hendes erfaringer med at undervise elever

- Pædagogmedhjælperen er en fantastisk relationsarbejder, en betydningsfuld voksen.

Der er som tidligere nævnt forskel på, i hvor stor udstrækning, pædagogmedhjælperne bliver inddraget i planlægningen af undervisningen og i udviklingen af arbejdsopgaver for eleverne. Denne forskel afspejler den opdeling i typer af rollefordelinger og samarbejdsrelationer, som kapitel 2 formidlede. Men for alle læreres vedkommende formuleres det, at pædagogmedhjælpere indtager en betydningsfuld rolle i undervisningen, og i relation hertil peges der på, at det at undervise den gruppe elever, som er på specialskolen, involverer mere end det rent fag-faglige. Det involverer det at finde løsninger på det at undervise specifikke elever (at udføre undervisningen), og det involverer en relationel kompetence i forhold til at forstå, hvordan elever bedst mødes og håndteres i praktiske situationer. To formuleringer i de ovenstående citater viser, at rollen, som pædagogmedhjælpere tildeles i nogle team, er mere adskilt fra en lærerfaglighed: 'Vi (dvs. lærere) har en plan, og så kan pædagogmedhjælperen gå ind og undervise' og 'jeg har en tryghed for, at det praktiske og omsorgsopgaver bliver udført til punkt og prikke'. De to formuleringer viser med tydelighed, at der eksisterer et hierarki, hvor lærerfagligheden er positioneret foran en pædagogmedhjælperfaglighed. 


\section{Pædagogmedhjælperes definition af egen rolle}

Pædagogmedhjælperne bevæger sig i samme adskillelse mellem nogle team, hvor der samarbejdes omkring undervisningen og andre team, hvor pædagogmedhjælpere ikke indgår i planlægning og forberedelse af undervisningen. Her udfoldes denne skelnen ud fra pædagogmedhjælpernes perspektiv og formuleringer. Først formuleringer, som angår pædagogmedhjælpere, som trækker sig fra at indgå i undervisningsplanlægning:

- Der er lavet et skema, så jeg ved, hvad jeg skal gøre. Jeg får lov til at være med til mange ting, men lærere har ansvar og siger, hvad vi skal gøre

- Jeg er meget klar på min rolle. Så længe jeg er her på skolen, så gør jeg nøjagtig ligesom de andre her på skolen. Hvis jeg får instruktion af andre, så går jeg ind og gør det, men jeg forbereder mig ikke på undervisning. Jeg går ikke ind og overtager forberedelsen. Det gør jeg, fordi jeg ikke får løn for det. Der er jeg meget klar

- Jeg går ind og underviser, når der ikke er nogle lærere, men jeg laver ikke elevplaner - det er ikke mit formelle ansvar

- Jeg tager ikke kun det praktiske - så kunne jeg stå på badeværelset hele tiden

Ovenstående formuleringer er karakteriseret ved, at være præget af negationer. Dvs. af en måde at definere sin rolle på, som negere eller adskiller sig fra en lærerrolle. I det efterfølgende vil formuleringer blive formidlet, som indkredser pædagogmedhjælperes forståelser af deres rolle som indeholdende elementer, der bidrager til den generelle pædagogiske og didaktiske praksis i specialskolen:

- Jeg er selv med til at bestemme, når jeg skal arbejde med et bestemt barn - vi snakker sammen, mig og lærer til teammøder

- I vores klasse arbejder vi en til en, så derfor må man som pædagogmedhjælper træde ind i undervisningen

- Nu har jeg jo erfaringer fra vuggestue-arbejde - det trækker jeg på, når vi skal have hverdagen til at fungere

- Jeg siger, hvad jeg mener til møder - kommer med input, og jeg bliver hørt

- Hvis der ikke er nogle lærere, så underviser jeg

- Jeg går ind og foreslår nye tiltag og måder at gøre ting på for elever, når jeg har nogle ideer. Så udvikler læreren det, og jeg formidler det videre til eleven 
- Ja, jeg synes, at jeg er god til at gå ind og fange hver enkelt elev på min måde, om det er en forhandling, eller det er klovneri, så synes jeg, at jeg er god til at gå ind og favne dem, hvor de lige netop er

- Altså, mit bidrag er nok, at jeg går ind og understøtter så meget som muligt

- Jeg synes at det, der skiller mig fra en pædagog, det er kun papiret og jeg har ikke papiret på det, men jeg synes, jeg er lige så kvalificeret som en pædagoguddannet

- Jeg bidrager nok og ser nogle ting og gør nogle ting på egen hånd.

Den eneste 'unge' pædagogmedhjælper, som har bidraget til undersøgelsen er ikke blevet interviewet. Hendes team, holdt teammøde med en psykolog, og der var ikke tid til interview. Det er karakteristisk for de ovenstående formuleringer, at det er erfarne og modne kvinder, der taler. Kvinder, som har været ansat på specialskolen i mange år, og som er godt integreret i det faglige praksisfællesskab med lærere, som i nogle tilfælde har færre arbejdserfaringer end pædagogmedhjælperne. Det kan være med til at forklare, hvorfor de påtager sig og tildeles en stor rolle $\mathrm{i}$ forhold til at gå ind og foreslå pædagogiske løsninger og måder at håndtere undervisningssituationer på samt bidrager med en nuanceret forståelse af eleverne. Af erfaringer, som de selv nævner, at de trækker på er følgende:

- Erfaring fra normalområdet

- Erfaring fra vuggestue arbejde

- Håndboldtræner

- Har bror med CP

- Leder i butik

- Trækker på stor søskendeflok

- Erfaring fra arbejde i børnehave.

En pædagogmedhjælper sætter ord på hendes rolle, som ansvarlig for at den samlede pædagogiske og didaktiske praksis fungerer, og at alle elever trives. Hun bruger ordet 'overblik' rigtig mange gange i den efterfølgende formulering:

- Min rolle er meget ansvarsfuld. Jeg synes, jeg har et stort ansvar for køkkenklassen, nogen gange måske lidt for meget. Mit ansvar det er, at klassen fungerer, eleverne har det godt og eleverne trives, og at de er i balance, synes jeg også. Jeg skal hele tiden have overblikket over både voksne og børn, synes jeg. Jeg føler måske nogen gange, at jeg skal have lidt for meget overblik, der skal jeg måske give lidt slip engang imellem. Men 
det synes jeg er svært. Jeg synes, vi lige skal snakke lidt mere med børnene, vi kan ikke bare gå henover hovedet på dem, så kan jeg godt lide at sige; ej, vi bliver nødt til lige at snakke lidt mere, vi kan ikke bare gøre tingene altså. På den måde føler jeg nok, at jeg skal have lidt for meget overblik.

- Ja, jeg tror ikke, jeg tænker så meget i årsplaner og vision, jeg tænker meget på at vores børn, elever, at de har det godt, hvor de er, og de har nogle voksne omkring sig, som vil dem det godt og vil være sammen med dem og prøve på at få et godt kammeratskab ud af det, det synes jeg er ret vigtigt. Så altså et sted, hvor de kan lide at være, og et sted, hvor de har lyst til at tage imod noget indlæring, det, synes jeg da, er en af de vigtigste opgaver.

Pædagogmedhjælperen, der formulerer sit ansvar og det nødvendige overblik indfanger en central rolle for pædagogmedhjælpere, som lærere ikke i samme udstrækning har fokus på - fordi deres fokus retter sig mod undervisning og læring. Det kan sammenfattes som det 'at alting fungerer' eller at det praktiske (mad, bleskift osv.), det pædagogiske (gruppen fungerer som gruppe), det omsorgsmæssige (eleverne mødes på deres følelsesmæssige behov på trods af sproglige barrierer) og det didaktiske (undervisningssituationer fungerer og konflikter tackles, når elever har modstand mod at indgå i undervisningen) spiller sammen på en hensigtsmæssig måde - dvs. på en måde, så alle trives. Den efterfølgende formulering indfanger ovenstående, sådan som pædagogmedhjælpere sætter ord på det:

- En kompetence, jeg har, er, at jeg kan hjælpe med til, at vi har nogle gode relationer sammen. De skal kunne mærke, at de voksne, de har omkring sig, de vil dem rigtigt gerne. Så det synes jeg er vigtigt. Og på den måde så er du jo også med til forhåbentligt, at lære dem noget, ikke? Fordi så har de også lyst til at lære noget

- Nogle gange kan det være en øjenåbner for lærerne, at vi ikke lægger for meget fagligt ind i det. Altså, jeg er nok lidt mere menneskelig og nede i et andet plan.

Pædagogmedhjælperne er ikke en homogen gruppe, når de beskriver deres rolle. Nogle er meget bevidste om ikke at gå ind i forberedelsen af undervisningen. Men samtidig er det et gennemgående træk hos samtlige pædagogmedhjælpere, at de i praksis (jævnfør observationer) og i deres egen selvforståelse indtager en betydningsfuld rolle. En rolle, som de anerkendes for af lærere, fordi den er central i forhold til at få undervisningen til at fungere, når målgruppen er elever med omfattende funktionsnedsættelser og generelle indlæringsvanskeligheder. 


\section{Skolelivet rummer langt mere end undervisning}

Det viser sig ved observationer i klasserum i forskellige feltstudier (HedegaardSørensen (2010a) og Hedegaard-Sørensen (2010b)), at et skoleliv består af en række andre aktiviteter end undervisning. En dag i skolen består af relationsdannelse, spisning, praktiske arrangementer, lege og social aktivitet i generel forstand og en række plejeaktiviteter.

Det samme gør sig gældende på den specialskole, som har været i fokus i denne undersøgelse, og det er en meget markant tendens. Når observationsmaterialet kigges igennem med henblik på forskellige typer af aktiviteter fylder 'tiden, hvor der undervises i fag' ganske lidt. Det, der fylder, er morgensamling, morgensang, pauser, børn, der venter (når deres kammerater bliver undervist 1:1), spisning og omsorg/pleje (toiletbesøg, skiftning af mad-maskiner osv.). På mange måder kan skolelivet på fokusskolen beskrives som en blanding af et arbejdsliv i en vuggestue og en skole. Der er etableret en fast rutine, som alle ansatte indgår i med henblik på at få det praktiske til at fungere: Morgensamling, morgensang, skoleaktiviteter, pause, skoleaktivitet, spisning, frikvarter, SFO eller flere skoleaktiviteter. Forskellen på en vuggestue og en skole er, at det, der foregår ved siden af de praktiske aktiviteter, det kan betegnes som læring og undervisningen. Som $i$ en vuggestue er det forudsætningen for at undervisningen (eller pædagogiske aktiviteter) kan fungere, at 'det praktiske fungerer'.

Det er både vigtigt, at eleverne får dækket en række behov, for at være i stand til at indgå i undervisningsaktiviteter og det er vigtigt, at gruppen trives. Hvis bare en elev ikke er i trivsel, kan vedkommende forstyrre (ved fx at skrige, at være meget urolig eller lignende), og målet om undervisning synes at være svært at realisere. Alene af den grund, at de øvrige elever, som for nogens vedkommende kan være sårbare over for mange impulser, bliver forstyrret af uro. Det særligt karakteristiske ved skolen er altså at 'det praktiske' og/eller 'det pædagogiske' (i betydningen få gruppen og enkeltindivider mødt på en måde, der skaber trivsel) fylder ganske enkelt en stor del af en skoledag på en specialskole. Disse 'andre aktiviteter' har en stor betydning og er derfor en væsentlig og fuldt integreret del af den faglige selvforståelse på skolen. Og målet for lærere og pædagogmedhjælpere er, at håndtere de udfordringer, som står i vejen for, at målet om at lære eleverne så meget som muligt fagligt, bliver realiseret.

Tidligere var den specialpædagogiske diskussion præget af et opgør med et stærkt fokus på omsorg og beskyttelse. Igennem de seneste år er der kommet et fokus på elevernes læring, på udfordringen af elevernes grænser og på udviklingen af deres kompetencer. Det viser sig på denne skole, at man ikke opererer med en enten-eller tænkning; dvs. enten et entydigt fokus på omsorg (det sociale, personlige og elevernes deficit) eller på læring (det faglige formål). 
På denne skole tænkes alle disse dimensioner sammen. Derudover - og sammenhængende hermed - er skolen karakteriseret ved, at arbejde med et meget bredt undervisningsideal. En anden måde at sige det på er, at de faglige formål tænkes i relation til elevernes funktionsniveau - læringen består i at blive mere selvhjulpen, at udvikle sit sprog, at udvikle sine fysiske funktionsevner (at gribe en bold fx). Det gør det muligt for lærere, pædagoger og pædagogmedhjælpere at tænke læring ind i skolens samlede aktiviteter. At finde læring og udvikling i hverdagens rutine; fx er der blik for, at nogle elever er meget optaget af musik, og netop disse elever bliver placeret tæt på klaveret ved morgensang, og der tales om musikken ind i undervisningsdelen. Musik og kreative aktiviteter fylder ganske meget i undervisningen også med udgangspunkt i en vurdering af elevernes behov og interesser, og fordi skolen er præget af en dannelsestænkning med brede personlige, sociale og faglige mål.

Et andet eksempel på samme tænkning er den vægt skolens ansatte lægger på det at gå i skole. I løbet af studiet på skolen er det flere gange - i uformelle samtaler - blevet pointeret, at skolen lægger stor vægt på, at eleverne skal gå på en skole og leve et almindeligt skoleliv som andre børn og unge. Derfor placeres eleverne ikke i klasser efter funktionsniveau, men i højere grad efter alder. Man lægger stor vægt på dannelsen af venskaber og sociale aktiviteter, som kan opstå, der støtter venskaber og giver eleverne mulighed for at have et børne- og ungdomsliv - på trods af funktionsnedsættelser. Det er en fuldt integreret del af den faglige selvforståelse, at 'alt det andet' har stor betydning, og at der også ligger læring, udvikling og dannelse i disse aktiviteter.

\section{Pædagogmedhjælpers rolle}

Og netop i relation til denne del har pædagogmedhjælpere en væsentlig rolle. De har ikke ansvaret for undervisningen og har derfor et blik for alt det, der foregår ved siden af undervisningen. $\mathrm{Og}$ alt det, som er en forudsætning for at undervisningen er mulig at realisere. Disse to størrelser hænger sammen i hverdagslivets praksis. En observationsdag i et klasserum kan udgøre et eksempel på, hvor centralt det er, at elevernes helt basale behov er dækket.

\section{Lort i undervisningen:}

$\mathrm{Nu}$ skal der males. Læreren fortæller, hvordan der skal males. En lærer og en nyansat pxdagogmedhjolper støtter eleverne $i$ at komme $i$ gang med at male. Ingen af dem kan selv hente lærred, farve og overkomme at male uden støtte fra en voksen. En af eleverne er til svømning, en (i kørestol) sidder og kigger $i$ baggrunden, to drenge er ved at komme i gang med at male, en pige, som har siddet $i$ gynge uden for lokalet kommer også ind nu. Der er to $i$ gang, to til at hjælpe og nu kommer der en tredje ind. Hun bliver taget ind, 
fordi hun hylede. Lxreren, som styrer aktiviteten, går ud og henter hende. Læreren forsoger at fä hende til at sætte sig ved bordet og male. Men det vil hun ikke. Den anden lexer tager over og forsøger, at få pigen til at indgå, men hun kaster sig vexk fra bordet og gør meget aktiv modstand mod at deltage. Alle ansatte omkring eleverne forsøger på skift at motivere pigen, men lykkes ikke. De resignerer en efter en og lader hende sidde, indtil den næste forsøger. Det lykkes aldrig og pigen laver en masse larm og uro, mens de andre elever maler og alle ansatte hjælper dem med det. De skal male en grundfarve på et larred. Efterhånden har fire elever fäet malet en grundfarve på et lærred. Når de alle er færdige, fortæller læreren, at nu skal malingen tørre. Den anden larer spørger, om det forst er i morgen, de skal arbejde videre. Og lereren, som har aktiviteten forklarer, at i morgen skal der puttes bogstaver på og andre former for dekorationer. Men det kan de ikke gøre nu, for malingen må tørre. En af drengene går ud og vasker hænder - han har fået meget maling på sine fingre. Nogle elever gør deres maleri helt fxrdigt. Drengen, der fra starten ikke havde lyst, kom lidt sent i gang, men har nu støttet kraftigt af en larer, fået malet sit billede. Lxreren viser en elev, hvordan bogstaverne ser ud, som hun har købt. Hun forklarer eleven, at de skal på lærrederne. Læreren viser, hvordan bogstaverne skal på og siger, at nu er der frikvarter, og der skal arbejdes videre i morgen.... Der sættes gang $i$ en masse praktiske aktiviteter, hvor maling, forklæder osv. skal ryddes væk, elever skal vaskes, nogle på toilettet og andre skal ind og dække bord, for nu skal der snart spises frokost. Pigen, som havde varet meget urolig, viste sig at have lavet lort $i$ sin ble. Den larer, som havde skiftet hende, kom ind og bad om assistance til bleskiftet.

Eksemplet viser, hvordan en pige i klassen er meget urolig, larmende og fuld af modstand mod at indgå i undervisningen. En lærer er i gang med at undervise i billedkunst, mens en elev - blandt en række andre elever, som har brug for assistance - fylder ganske meget. Det ville ikke være muligt for den lærer, som står for undervisningsansvaret at håndtere denne elev uden hjælp fra andre. I starten af aktiviteten er pædagogmedhjælperen i klassen i gang med at give en pige den pleje, som hun har brug for. Hun skal sonde-mades, og hendes hår skal redes, efter at de har været i svømmehallen. En 'vikar' er i klassen og er den, der assisterer læreren i forhold til pigen, der er i rummet, hvor der undervises i billedkunst. Som det fremgår af eksemplet lykkes det ikke at få pigen til at finde ro i at indgå i maleaktiviteterne. Det viser sig, da der skal spises frokost, at pigen har lavet 'lort' i sin ble. Hun har ikke noget verbalt sprog, og derfor er det svært for hende at fortælle, at hun har et behov. De ansatte i klassen har travlt med at få alting til at fungere, så de bemærker ikke, at hun har det behov, som hun har. Det er et eksempel på, hvor vigtigt det er, at teamet har lavet afta- 
ler med hinanden om, hvem der sørger for hvad. For at dette ikke sker. Af etiske grunde, men også i relation til at få undervisningsaktiviteter til at fungere uden konflikt og uro. Eksemplet er ikke inddraget for at signalere, at dette er typisk for skolen. Det er det ikke, og det er meget forståeligt, at noget kan glemmes. Det er væsentligt at komme i hu, at der er mange elever med forskellige plejebehov og behov for omsorg. Derfor - og for at sikre sig, at alle elevers behov er dækket - tildeles i alle klasserum hver elev en 'voksen' (pædagog, pædagogmedhjælper eller lærer), som har ansvaret for, at elevernes behov for mad, toiletbesøg osv. bliver dækket. I et planlægningsmøde til en lejrtur brugte teamet halvdelen af mødet på at fordele 'voksne' til eleverne, sådan at teamet var helt sikker på, at alle elever blev 'passet på'. En sådan fordeling laves ikke kun, når der er ændringer i aktiviteter som en lejrtur, men det blev tydeligt, hvor centralt det står, og eksemplet forklarer hvorfor.

Pædagogmedhjælpere indgår i teamets samarbejde omkring undervisningen netop med henblik på at få alle de behov dækket, som eleverne har, og som er en forudsætning for at målene, skolen har, kan realiseres. En pædagogmedhjælper i interview sætter ord på, det ansvar, som hun tager, netop for dette.

- Mit ansvar det er, at klassen fungerer, eleverne har det godt og eleverne trives, og at de er i balance, synes jeg også. Jeg skal hele tiden have overblikket over både voksne og børn, synes jeg.

Her endnu et eksempel på, hvor mange opgaver, som ansatte - i fællesskab skal løse på en ganske almindelig skoledag.

\section{Kompleksitet og travlhed:}

Der er en overgang fra morgensamling til frikvarter. En af eleverne havde fået æblekage i går, og det blev der talt om, da elevens kontaktbog blev gennemgået. En af drengene vender tilbage til æblekagen og siger, at han hader xblekage. Pædagogmedhjælperen siger til ham, at han da godt kan lide æblekage. De griner sammen ... I frikvarteret skal en masse praktiske ting klares. Eleverne skal på toilettet (nogle skal have skiftet ble), de skal have noget at spise eller sættes $i$ gang med aktiviteter. Ingen af eleverne er selvhjulpne $i$ den forstand, at de selv går i gang med en aktivitet. Alle ansatte har meget travlt med at nå rundt om alles behov, og de aftaler undervejs $i$ travlheden, hvem der gør hvad. På et tidspunkt er alle faldet til ro $i$ en aktivitet. De to pædagogmedhjælpere og en lærer snakker om, hvad der skal ske efter frikvarteret. Den faste pædagogmedhjxlper skal over og svømme med en pige. En af de to elever, som sidder $i$ kørestol, uden verbalt sprog og uden evnen til at kommunikere ud over med blikket. Pædagogmedhjælperen giver hende noget mad, og hun pakker svømmetøjet sammen. Pædagogmedhjælperen taler hele 
tiden med pigen om, hoad hun gør. Den nyansatte pædagogmedhjælper viser noget frem, som hun har lavet til deres kunstprojekt. Klassen skal have billedkunst, når timen starter og pædagogmedhjelperen er ved at lave nogle forberedelser. Læreren, som har været til stede under morgensamling indgår på lige fod med pædagogmedhjolperne $i$ at fà det praktiske til at fungere.

Det er en væsentlig pointe med eksemplet, at pædagogmedhjælperes rolle er at have overblikket og at støtte lærere i at få dækket alle elevernes behov, men det er samtidig en vigtig pointe, at det er et ansvar, som ikke kun pædagogmedhjælpere tager. Når en lærer i et interview siger, at hun føler sig lidt pædagogagtig, er det et eksempel på, at lærere også tager dette ansvar.

\section{Sociale roller og positioner}

Et samlende og konkluderende perspektiv på ovenstående analyse peger på, at der er en tydelig forbindelse mellem det specialpædagogiske arbejdes karakter, den faglige selvforståelse på skolen og de roller, som lærere, pædagogmedhjælpere (og pædagoger) indtager og tildeles. Et skoleliv på en specialskole, som den der har været i fokus i indeværende undersøgelse kalder på, at en række opgaver løses og en række situationer håndteres. Disse opgaver må løses, for de er en forudsætning for, at hverdagslivet fungerer (både på gruppe- og individniveau), og for at målet om undervisning realiseres. Som det vil være fremgået af analysen, synes lærere at anerkende dette vilkår.

Lærere synes at være opmærksomme på, at de selv må trække på andre faglige dimensioner end undervisningen i fag. 'Jeg er nok lidt pædagogagtig', siger en lærer og peger dermed på, at det at være lærer på en specialskole kalder på et bredt undervisningsideal og på en anerkendelse af, at der må pædagogiske faglige dimensioner ind i det pædagogiske og didaktiske arbejde på en specialskole. Samtidig hermed udtrykkes det, at pædagogers rolle i skoledelen er mere udfordrende end pædagogmedhjælpernes rolle.

Pædagogerne opstiller andre mål end de mål, som lærere stiller. Det bliver af nogle lærere betragtet som en måde at reducere eller udvande de væsentlige fokus på elevers ret til læring - i modsætning til omsorg - som lærere lægger stor vægt på. Pædagogmedhjælperes rolle, som dem der understøtter undervisningens gennemførelse - $\mathrm{i}$ et samarbejde med lærere - er en rolle, som både pædagogmedhjælpere og lærere er enige om på skolen. I relation til Fibæk Laursens definition af professioners kamp om territorier, synes der ikke at være en frygt hos lærere for, at de mister territorium, når roller fordeles mellem lærere og pædagogmedhjælpere.

Det opleves at være uproblematisk for lærere og pædagogmedhjælpere at overskride de stereotype sociale roller (Goffman), som henholdsvis lærer og 
pædagogmedhjælper. En måde at tænke mere stereotype roller på kunne være at lærere fastholder retten til at undervise, og pædagogmedhjælpere fastholder retten til ikke at undervise. Pointen med den analyse, som er foretaget, er, at det ikke i det praktiske arbejde giver mening at holde disse roller adskilte. Lærere ved, at det er en forudsætning for at kunne realisere mål om undervisning, at de tager et fælles ansvar for 'alt det andet'. Samtidig hermed fastholdes de sociale roller, og de anerkendes af begge parter. Lærere ved, at de har ansvaret for at leve op til folkeskolens formål og at planlægge og dokumentere elevernes læring. Og pædagogmedhjælpere anerkender, at det er lærernes kompetence og ansvar og udviser en respekt for det.

En rolle, som endnu ikke er beskrevet tydeligt, er pædagogmedhjælperens rolle, som består i at undervise. Det vil komme i fokus i næste kapitel omkring samarbejde i praksis. Som det vil være fremgået af de ovenstående analyser, viser det sig, at rollefordelingen mellem lærere og pædagogmedhjælpere ikke består i, at pædagogmedhjælpere ikke underviser, men i at pædagogmedhjælpere ikke har ansvaret for at sætte mål og at planlægge og dokumentere læring. 


\section{Kapitel 4. \\ Samarbejdets former}

Dette kapitel retter opmærksomheden på samarbejdet mellem lærere og pædagogmedhjælpere i konkrete undervisningssituationer og på det tværfaglige samarbejde med eksterne faggrupper. Det empiriske grundlag er den observerede praksis samt feltnotater fra observationer af teammøder. Det første afsnit 'Samarbejde omkring undervisning' fokuserer på, hvordan lærere og pædagogmedhjælpere samarbejder omkring undervisningen i fag i praksis, og det næste afsnit 'Specialiseret viden i praksis' diskuterer det hierarki, som opstår, når den specialiserede viden diskuteres imellem faggrupper i relation til den ligeværdighed, som opstår, når den mere almene diskussion om praksis og håndteringen af den, diskuteres og evalueres.

Analysen trækker på Goffmans teori om, hvordan det sociale liv kan ses som en teaterforestilling, hvor mennesker spiller roller i samspil med hinanden i konkrete situationer. Antagelsen er, at mennesker tilpasser roller til hinanden i interaktion, og i denne undersøgelse er der fokus på den interaktion og gensidige tilpasning, som lærere og pædagogmedhjælpere har over for hinanden i praksissituationer og den interaktion, der udspiller sig på teammøder med og uden eksterne konsulenters deltagelse. Det er først og fremmest den ikke verbale og situationsbundne type af kommunikation, som Goffman inviterer til at fokusere på - en ikke intentionel og bevidst form for kommunikation. Det er en form for kommunikation, som han antager mennesker overfører på hinanden, for at opnå en bestemt form for definition af situationen og for at styre andres opfattelse. Dette ikke verbale niveau forsøger analysen at indfange, hvor analysen i kapitel 3, mere havde fokus på det, som lærere og pædagogmedhjælpere italesatte på et mere bevidst niveau. Her er ambitionen at indfange det, som foregår backstage, bagom det sagte og det umiddelbart observerbare. Det analytiske blik retter sig derfor mod den måde, teamet kommunikerer på, når de holder møde, og når de arbejder i praksis. Det, de siger om deres praksis, og måden de siger det på, og de forskellige roller de indtager i forhold til hinanden her. Også i relation til de faglige formål, som specialpædagogisk arbejde er skrevet ind i (jævnfør Barth). Oprindeligt var det en intention i studiet at indfange det, som lærere og pædagogmedhjælpere sagde til hinanden - aftaler om hvem der gør hvad osv. - mens arbejdet stod på. Det viste sig imidlertid, at der 
var meget lidt samtale under interaktion. Måske fordi arbejdet ikke levner meget plads til det og måske, fordi det er en intention ikke at tale 'hen over hovedet på eleverne', som de ansatte selv ofte formulerer som en intention, de har.

\subsection{Samarbejde omkring undervisning}

Som omtalt har pædagogmedhjælpere en rolle også i forhold til undervisningen. Indtil nu er pædagogmedhjælperes rolle beskrevet i relation til det praktiske mesterskab, som består i at få alting til at glide i hverdagen omkring elevernes individuelle behov for omsorg og pleje og at få gruppen til at fungere, som en forudsætning for at undervisningen kan realiseres. I dette kapitel rettes blikket mod pædagogmedhjælpernes rolle, når det angår undervisningen i fag. Som det fremgik af kapitlet om roller (kapitel 2), spiller pædagogmedhjælpere to væsentlige roller i forhold til undervisningen. De assisterer lærere, når lærere underviser, og de underviser også selv - nogle gange ved at stå for en undervisningsaktivitet for en gruppe (det er dog sjældent) og andre gange ved at undervise eleverne 1:1 (hvilket ofte forekommer, særligt i nogle klasserum). I dette kapitel vil opmærksomheden blive rettet mod pædagogmedhjælperes funktion i samarbejdet med lærere omkring undervisningen - dvs. når undervisningen udføres. Her trækkes først og fremmest på observationsmateriale, men også i nogen udstrækning på observation af teammøder.

\section{Undervisning i praksis}

Det har været en gennemgående akse i undersøgelsen, at der er forskel på at vide noget teoretisk (det symbolske mesterskab) og at være i stand til at handle i konkrete praktiske situationer (det praktiske mesterskab). Pierre Bourdieu skriver i bogen 'Af praktiske grunde' (Bourdieu (1997)), at 'subjekter er handlende og vidende agenter, som har en praktisk sans' (ibid. s. 44), og med det henviser han til et praktisk mesterskab, som består i et 'handlingsskemata' eller en 'habitus', som orienterer mennesker i forhold til at handle i konkrete situationer og vurdere, hvilket svar der passer til konkrete situationer. Agenternes habitus 'er denne form for praktiske sans for, hvad der skal gøres i en given situation' (ibid., s. 44) og kan beskrives som en sans for spillet. Denne praktiske sans udspiller sig i relation til de 'objektive strukturer', som mennesker handler under, men ikke sådan, at de objektive strukturer bestemmer, hvad der kan gøres. Det som bestemmer vurderinger, opfattelser af og handlinger i konkrete situationer er en praktisk sans for at gøre det, som skal gøres her og nu. Der er ikke uendelige muligheder for at vurdere og handle - men der eksisterer et rum af muligheder. Man kan beslutte mange handlinger, men nogle handlinger vil 
være utænkelige. Det afhænger af det felt, man er situeret i, og de teorier og faglige forståelser, som er anerkendte i dette felt. Overført til specialpædagogisk praksis vil der være mange mulige (men dog begrænsede muligheder) holdninger til, vurderinger af og handlinger i situationer. Det er det enkelte handlende individ, der beslutter at handle i relation til konkrete situationer og i relation til det, der er muligt både praktisk, men også i forhold til den lokale faglige kultur (eller enighed om formål og fælles situationsdefinition, som et team har skabt over tid). Denne form for viden erhverves ved at deltage i livet - via socialisation og via mesterlære i en given praksis - og er en anden form for viden, end den, der tilegnes via uddannelse. Det er en viden, som relaterer sig til konkrete situationer.

I Schöns teori om professionel handlen udvikles en lignende teori. Her anskues den praktiske viden (viden i handling) ligeledes som en anden form for viden end den viden, som findes i akademiske lærebøger og i videnskabelige rapporter; det vil sige i teori og model (Schön 2001). Schön trækker Edgar Schein ind, som gør op med forestillingen om, at generelle principper (teori) for professionel kompetence ligger øverst i et videnshierarki, og at den konkrete problemløsning ligger nederst. Schein peger på, at der er tre komponenter i professionel viden: 1) en underliggende disciplin eller grundlæggende videnskab, som praksis baserer sig på, 2) en anvendt videnskabs- eller ingeniørviden, som daglige problemløsninger er uddraget fra, samt 3) færdigheder og tilgange til ting, som har at gøre med den udlevede praksis (Schön 2001).

Det, som fokuseres på i denne undersøgelse, er den udlevede praksis og de måder at samarbejde på i praksis, som finder sted i den udlevede praksis. Og fokus er på undervisningssituationer. Når pædagogmedhjælpere indgår i undervisningssituationer i den daglige praksis er det netop denne form for viden, de trækker på. Jævnfør pædagogmedhjælpernes tale om deres kompetence i kapitel 3. Det er en viden, som ikke har med teorier og færdige begreber at gøre, men som kan beskrives som en praktisk kompetence i divergerende situationer (Schön 2001).

\section{Didaktik i divergerende situationer}

Uljens (1993) teori om procesdidaktik indfanger netop, hvordan det at undervise elever i praksis involverer en in-situ-planlægning og justering af den plan for undervisningsforløbet, som læreren måtte have forud for undervisningen. Det er en teori, der teoretisk belyser, hvordan undervisningens praksis er bestemt af kompleksitet og uforudsigelighed. Uljens tilbyder en forståelse af, hvordan det er muligt, at leve op til mål for undervisning (nationale mål og lokale mål) ved at tænke og praktisere undervisning på en måde, som er tilpasset elevernes måde at være elever på. Han introducerer "Den pædagogiske flue", som er en mo- 
del over den didaktiske handlen. Den består af tre dele: Planlægning, udførelse og evaluering. Planlægningen deles ind i to niveauer: Det kollektive (nationale og kommunale lærerplansniveau) og lærerens planlægning (årsplaner, ugeplaner og planlægning af lektion). Uljens laver yderligere en deling af planlægning, nemlig planlægningen, som kommer forud for den direkte didaktiske handling, og planlægningen, som foregår i selve undervisningssituationen. Han betegner denne type planlægning som en "in-situ-planlægning". På samme måde tænker Uljens den evaluerende dimension. Den tænkes også som evaluering i selve undervisningsprocessen og som evalueringen af aktiviteter og resultater efter undervisningens gennemførelse.

Teorien fokuserer på didaktik i bred forstand og er altså ikke rettet specifikt mod det specialpædagogiske område. Det er en teori, som ifølge forskellige empiriske studier (Hedegaard-Sørensen (2010a) og (2010b)) indfanger det vilkår, som karakteriserer den observerede praksis i klasserum bredt, men måske især i specialpædagogiske læringsmiljøer, at eleverne ikke bare sådan uden videre indgår i den planlagte undervisning. Der eksisterer en række afbrydelser og uforudsete hændelser i alle de nu'er, som finder sted i en undervisningssituation. En række nu'er, som situationer rummer og som alle må håndteres af det faglige fællesskab, som varetager undervisningen. Det er, som det er fremgået primært lærere, der har ansvaret for undervisningen og for planlægningen af den, men som det vil fremgå af den efterfølgende empiriske analyse, er undervisningssituationer karakteriseret ved så stor grad af uforudsigelighed og afbrydelser, at både lærere og andre faggruppers opgave bliver sammen at håndtere disse, sådan at målet om at eleverne lærer noget indfris. Pædagogmedhjælpernes rolle i et tværfagligt samarbejde med lærere kan defineres i relation til netop denne dimension af undervisningens praksis på en specialskole.

De nævnte teorier om 'det praktiske mesterskab', 'viden i handling' som noget andet end teoretisk viden samt teorien om in-situ-planlægning og evaluering indfanger en helt central det af det, som sætter dagsorden for det samarbejde omkring undervisningen, som karakteriserer samarbejdet mellem lærere og pædagogmedhjælpere på specialskolen i dette studium. Det er en væsentlig specialpædagogisk kompetence at være i stand til at reflektere i handling, skønne, vurdere og justere, når målet om at lære elever i omfattende vanskeligheder gennem undervisning i fag. Det er denne kompetence, som er betegnet som en situeret professionalisme (Hedegaard-Sørensen (2011)). Og det er netop denne kompetence, som lærere og pædagogmedhjælpere er sammen om at udfolde i praksis, når de samarbejder omkring undervisningen. 


\section{Samarbejde om undervisning - i praksis}

På specialskolen, som denne undersøgelse er foretaget på, er det, som i de pædagogiske feltstudier, der er refereret til, en typisk og hyppigt forekommende udfordring at få undervisningen til at lykkes og at få eleverne motiveret til at indgå i undervisningssituationer. I det efterfølgende vil eksempler fra observationsdelen på dette blive formidlet og derfra vil samarbejdet mellem pædagogmedhjælper og lærer bliver indkredset.

Her et eksempel fra observationsstudierne på specialskolen, som viser med tydelighed, at pædagogmedhjælperen har en væsentlig rolle $\mathrm{i}$ sammen med læreren løbende at tilpasse og justere undervisningens plan og mål til elevernes måde at indgå i situationen på. Dvs. til elevernes reaktioner, konflikter osv. Læreren i aktiviteten, som har lederskabet - indtager rollen som klasserumsleder - og pædagogmedhjælperen evner at ændre situationen og gribe ind i situationen, når noget uforudsigeligt sker. Og det sker hele tiden. Hvad der også er væsentligt at bemærke er, at det at undervisningen løbende må ændres og justeres i et samarbejde mellem lærere og pædagogmedhjælpere i situationen ikke betyder, at forberedelsen er uvæsentlig, og det at stille mål op for aktiviteter er uvæsentlig. Og her har lærere en stor rolle.

\section{Afbrydelser og nye situationer:}

Efter frikvarter skal drengene fra klassen til gymnastik sammen med nogle drenge fra klassen ved siden af. De skal over i en hal, som ligger lidt vak fra klassen, men på skolen. Drengene folges med lareren over til hallen. De siger 'yoghurt' til hinanden og griner og fjoller. Humøret er højt. Lareren siger: 'Hold nu op med at sige sådan!'. Mens de klæder om, fortsætter de med at pjatte og sige 'yoghurt'. Læreren siger igen, at hun synes de skal stoppe. En dreng råber fra toilettet, at det jo bare er for sjov. Da drengen kommer ud, snakker drengene og læreren om, at de skal spille hockey. De fär efterhånden alle klædt om og mødes inde $i$ hallen. Når de kommer ind $i$ hallen, begynder de at løbe rundt, sammen med larere og pxdagogmedhjxlpere. Pædagogmedhjælperen (den faste) er ikke kommet endnu. Hun skal være sammen med en dreng, som er bange for gymnastik. Så hun skal folge ham stille og roligt derover og vare omkring ham under gymnastiktimen. De kommer ind på et tidspunkt, hoor alle elever lober rundt. En af eleverne kører $i$ rullestol, men ellers er alle drengene gående og lobende. Drengen, som er sammen med pædagogmedhjælperen, kom lidt forsigtigt ind, men da eleverne samles $i$ en rundkreds, for at lave fxlles opvarmning, stiller han sig ind $i$ rundkredsen og ser positiv og forventningsfuld $u d$. Læreren styrer opvarmningen, og de øvrige ansatte er med som assistenter. Den unge pædagogmedhjælper orienterer sig løbende efter de elever, som sakker bagud el- 
ler signalerer, at de har det svært. Pædagogmedhjælperen er med for at passe på den dreng, som er bange for gymnastik, men de andre tilstedeværende, som er læreren og pædagogmedhjælperen fra en anden gruppe, de er også assistenter $i$ denne lektion. Lareren siger, at de nu skal ind og hente bolde. Alle går ind $i$ et rum for at hente bolde, mens den for omtalte dreng og pxdagogmedhjilperen løber rundt, for det nåede de ikke, fordi de kom for sent. De andre går i gang med at bygge en bane, som alle skal igennem. Læreren styrer og sætter andre i gang og meget hurtigt har born og voksne bygget en bane. Lxreren styrer alle elever hen til starten af banen og sætter dem $i$ gang. Hun er en autoritet, hun leder, hun kommanderer, men samtidig er hun meget rummelig, eftergivende og støttende, når elever støder på nogle udfordringer. Hun råber støttende og opmuntrende kommentarer til eleverne, når de kæmper sig igennem banen. Og hun når at rose alle, der gennemforer. Nogle elever gynger i nogle reb. På et tidspunkt går Niels og læreren hen til et reb, og Niels går i gang med at gynge. Han synes at nyde det, og læreren tager en filmoptagelse af ham. Efter et stykke tid pakkes alle genstande til aktivitetsbane og gynger sammen. Nu skal de spille hockey. Læreren er den, der først og fremmest står for oprydning, og hun forsøger at få drengene inddraget. Det lykkes hun med. De sætter sammen nogle mål op og finder nogle hockey-stave. Hurtigt fordeler de hold, og spillet går i gang. Niels og pædagogmedhjælperen startede med at være målmand, men hurtigt trækker Niels sig væk fra spillet. Han fär lov af pædagogmedhjælperen til at sidde på en madras og kigge. En anden elev sættes lige ind som målmand, mens pxdagogmedhjælperen hjælper Niels over på madras. Pædagogmedhjxlperen går ind $i$ spillet igen og spiller $i$ marken. Hun lader målmanden fortsætte som målmand. Hun fär en stav, fordi en af drengene (ham i kørestol, som er med uden kørestol og som skubber sig frem) lige holder en pause. De spiller og på et tidspunkt kommer drengen ind igen og insisterer på at få sin stav. Det fär han og han spiller med igen. Pxdagogmedhjælperen bliver hurtigt derefter målmand sammen med en anden elev. Hun holder, mens hun er målmand, øje med Niels, som sidder på en madras og kigger. Da de er færdige, og der skal ryddes op, opstår der en konflikt mellem to af drengene. Det hold, som tabte, havde en spiller, som var meget frustreret over at tabe. Det gik ud over modstanderen. Lxreren går ind og spørger drengene, hvad der skete, og går ind og hjælper dem med at afslutte konflikten. Hun taler med dem om, at man skal kunne tåle at tabe uden at slå sine modstandere, men at det kan være svært at tabe. Og at det nok var derfor, en af drengene havde slaet. Fordi han var træt af at tabe.

Det er vanskeligt at indfange skriftligt, hvor mange gange i løbet af denne undervisningslektion, at uforudsete begivenheder indfinder sig. Det sker ca. to 
gange i minuttet, at en bestemt elev må håndteres eller støttes for at kunne være i situationen. Lærer og pædagogmedhjælpere har en non-verbal kommunikation, hvor de sammen er enige om at gribe ind der, hvor der er brug for det. De bevæger sig og forholder sig hele tiden undersøgende i forhold til hinanden og i forhold til den situation, som de står i lige nu, lige nu og så i næste lige nu. Polkinghorne (2004) sammenligner denne type professionalisme med det at spille i et jazz-orkester, hvor hvert enkelt medlem af orkestret improviserer, toner sig ind på hinanden og på den musik, som de fælles skaber (Polkinghorne (2004), s. 120 og Hedegaard-Sørensen \& Tetler (2011)). Det er et billede, som dækker den type samarbejde i praksis omkring praktiske situationer, som karakteriserer samarbejdet mellem lærere og pædagogmedhjælpere. Der træffes en række beslutninger $\mathrm{i}$ et fællesskab og i relation til det, der er i gang lige nu og her - det er en form for situeret vurdering i tid og på sted, som er en ganske væsentlig kompetence at have for at håndtere kompleksiteten i undervisningssituationer.

I relation hertil er det, som Goffman peger på det, centralt at være enige om, hvordan situationer skal defineres. Altså om, hvad der er væsentligt at prioritere lige nu og her. Det forudsætter en fælles forståelse af den specialpædagogiske opgave, som teamets medlemmer løser sammen. En sådan fælles enighed træder frem, når det specialpædagogiske arbejde observeres. Der synes ikke at være diskussioner og misforståelser i praksis eller på møder om praksis om, hvad der er vigtigt at prioritere i det specialpædagogiske arbejde og ej heller om, hvem der gør hvad og hvornår. Det vendes der tilbage til i det efterfølgende afsnit om samarbejdsformer på skolen.

\section{At undervise 1:1}

Her to eksempler fra observationsdelen på en rolle, som er meget central for pædagogmedhjælpere på specialskolen. På skolen, hvor undersøgelsen er foregået er der, som omtalt, en tæt forbindelse mellem specialiseret viden og metoder og undervisning. Pecs, social stories, piktogrammer, visualiseringer er eksempler på dette, men også individuelt tilpassede opgaver, som går ind og støtter elevernes kommunikation, begrebsopfattelse osv. I alle klasserum har eleverne individuelle arbejdsborde. I nogle klasserum ligger undervisningsmaterialer på hylder, som de undervises efter 1:1 og i andre klasselokaler ligger undervisningsmaterialerne, som også er individuelt tilrettelagt, forskellige steder i klasserummet. Fælles for alle klasserne er det, at der er ganske stort fokus på individuelt tilrettelagt undervisning, som i vidt omfang kan beskrives som kompensatorisk - i den forstand, at de er udviklet i samarbejde med talepædagog eller psykolog i relation til individuelle elevers funktionsnedsættelse. Som omtalt før tilrettelægges undervisningen i alle team, således at fællesundervis- 
ning udgør en ringe del af undervisningsaktiviteterne. Det er den individuelle undervisning, som prioriteres. Det betyder i praksis, at eleverne undervises enkeltvis på skift. Når eleverne ikke undervises, holder de pause. Pausen kan bestå i at sidde ved en computer, som også har et fokus på læring eller på leg og læring. Pausen kan også bestå i at høre musik, at sidde og lege med noget alene eller at lege sammen med andre (det er dog sjældent, at eleverne vurderes at kunne det). Typisk vil der være tilknyttet en lærer og en pædagogmedhjælper til 4-5 elever. I nogle klasserum vil elevgruppen være sådan sammensat, at en eller flere elever ikke indgår i undervisningen, men tages væk fra undervisningen sammen med en voksen. De kan fx være i svømmehallen, gå en tur i området, være inde i salen og høre musik.

Denne organisering betyder, som det fremgik af ovenstående, at der hele tiden må være en klar og aftalt rollefordeling mellem ansatte om, hvem der gør hvad og hvem der har ansvaret for hvem. Det er en planlægning, som fylder rigtig meget i den daglige praksis, når der er sygdom osv. Puslespillet falder hurtigt fra hinanden, hvis en af brikkerne mangler. Det overblik over den samlede gruppe, som pædagogmedhjælperne påtager sig, hænger nøje sammen med at få brikkerne til at falde på plads, sådan at der skabes rum for individuel undervisning ud fra individuelt tilrettelagte undervisningsmaterialer.

Som konsekvens af prioriteringen af individuel undervisning og et begrænset antal lærere, bliver det en nødvendighed, at pædagogmedhjælpere også underviser individuelt. Den valgte organisering af undervisningen i 1:1 undervisning betyder helt konkret, at læreren og pædagogmedhjælperen begge sidder med hver en elev. Når den elev er undervist færdig går de videre til den eller de næste elever. Som det vil fremgå af de to eksempler, kalder det at få eleverne motiveret til at indgå i individuel undervisning på en praksiskompetence, som både pædagogmedhjælpere og lærere må besidde for at kunne indfri målet om læring. Det er en praksiskompetence, som fordrer en situeret professionalisme og en relationskompetence, fordi situationen kalder på at håndtere elevernes indfald, konflikter og modstand mod at indgå i undervisningssituationer. Her det første eksempel:

\section{Afbrydelser og uforudsigelighed:}

Pædagogmedhjælperen skal undervise en pige 1:1. Pigen sidder ved et bord for sig selv og laver et eller andet. Hun er helt stille. Pædagogmedhjælperen tager en stor mængde opgave-plader og opgave-ark frem. Hun sætter sig ved siden af pigen. Da hun skal i gang, kommer der nogle ind fra lokalet ved siden af og spørger til en stol. Pædagogmedhjælperen giver dem stolen, og hun lukker døren. Nu går pædagogmedhjælperen $i$ gang med at undervise pigen. Pædagogmedhjælperen lægger en plade på bordet foran hende. Hun tager den. Pædagogmedhjælperen siger: 'Ja, du elsker den plade'. Pædagog- 
medhjælperen gennemgår pigens kontaktbog. Der ligger en bog foran dem med billeder af de elever, som hun går $i$ klasse med. Pxdagogmedhjælperen spørger: 'Hvor er Dennis?' Hun laver tegnsprog til pigen, når hun spørger. Pigen bladrer i bogen. Hun bliver meget glad, da hun ser billedet af sig selv. Der sættes to billeder på en tavle, og pigen skal tage det billede ned, som pxdagogmedhjxlperen foreslår. Det er stadig billeder af eleverne $i$ klassen. Pigen tager det rigtige billede og roses for, at hun er dygtig. Hun smiler, griner og bevæger sig frydefuldt. Nu sættes mange billeder på en plade. Pigen skal finde Rasmus. Pædagogmedhjælperen siger: 'Kan du finde Rasmus?' Pædagogmedhjolperen viser et billede af Rasmus og spørger igen. Pigen peger på Dennis igen. Pædagogmedhjælperen tager nogle af billederne væk og siger: 'Find Rasmus'. Pigen tager et billede af Nikolas. Pædagogmedhjælperen siger: 'Er der ikke hul igennem?'. Til sidst tager pigen billedet af Rasmus og fär ros for det. Pædagogmedhjælperen beder pigen om at tage et nyt billede. Hun gør ikke tegn til at tage et billede. Pædagogmedhjælperen spørger: 'Har du ikke lyst? Kan du ikke li' ham? Skulle du ikke vise, hvor dygtig du er?'. Pædagogmedhjælperen siger, at hun ikke vil tage den dreng, som læreren er sammen med (impulsstyret og gør skade på sig selv og andre), fordi hun er vred på ham.

Der er nu tre billeder på tavlen. Det ene billede er af pigen selv. Hun kigger på sit eget billede. Pædagogmedhjælperen siger: 'Du kigger på dig selv'. 'Jeg tager det billede ned'. Det er meningen at hun skal tage et andet billede ned - et billede af en af sine kammerater. Pædagogmedhjælperen tager det ned. Pigen vil have billedet. Hun rækker ud efter det. Billedet sættes på igen. Pigen vil ikke tage det billede af Mads, som hun bliver bedt om at tage. Pædagogmedhjælperen siger: 'Så tage billedet af dig selv'. Da de er fxrdige med denne opgave tager pxdagogmedhjælperen pigens familiealbum frem. Hun siger: 'Skulle vi tale om det?' 'Du har været på Skelbakken'. (En institution, hvor eleverne bor eller kommer $i$ aflastning). Pigen bliver meget glad, da hun ser et billede af sig selv. Pædagogmedhjælperen siger, at de skal arbejde lidt med noget andet, og så kan de kigge på familiebilledet bagefter. Mens de sidder og arbejder kommer en ung mandlig pædagogmedhjælper ind og spørger, om pædagogmedhjælperen kan hente to elever. Pædagogmedhjælperen siger: 'Jeg henter hende, når jeg er færdig'. Pædagogmedhjælperen viser pigen, som hun arbejder meden masse plastik-dyr og siger, hoad dyrene hedder. Pigen skal tage elefanten. Hun peger på elefanten og tager den efter et stykke tid. Pædagogmedhjælperen siger: 'Nu er det slut, du er ikke koncentreret $i$ dag, så nu skal du ind i salen til Jonas (den unge pædagogmedhjolper). 
Eksemplet viser, at pædagogmedhjælpere fint kan gå ind og undervise, og at denne pædagogmedhjælper har tilegnet sig en kompetence til at kommunikere med elever, der ikke har verbalt sprog. Hun kigger intenst på pigen, hun sætter ord på pigens tegn, hun bruger tegnsprog, hun forsøger at læse hendes signaler, og hun arbejder intenst på, at pigen lærer at udtrykke sig og at blive selvhjulpen. Og hun bruger de kommunikationsstøttende materialer, som er udviklet i et samarbejde mellem lærere og talepædagog.

Et andet forhold, som må bemærkes, er, at pædagogmedhjælperen samtidig har overblikket over den samlede situation. På observationsdagen er hun alene med to piger. Læreren, som er tilknyttet klassen (gruppen, for klassen er delt i to), har opgaven denne formiddag været at 'mandsopdække' en meget impulsstyret og selvskadende elev. Hvis han ikke 'mandsopdækkes', kontakter han de andre elever på en meget voldsom måde og kaster med inventaret. Pædagogmedhjælperen har ansvaret for alle elever i gruppen og bliver flere gange i løbet af timen afbrudt. Enten fordi en manglede en stol eller også fordi en spurgte, hvad han nu skulle gøre.

Det spørgsmål, som den unge pædagogmedhjælper stiller, udtrykker fint, at der, på trods af aftaler og planer, hele tiden opstår nye situationer, hvor nogle 'ansatte' skal overtage elever fra andre ansatte. Det er ikke muligt at planlægge helt i detaljer, for det er uforudsigeligt, hvor længe det tager at undervise - det afhænger af elevernes motivation og parathed. Samarbejdet kan beskrives som en organisk enhed, hvor der er lavet en masse planer og aftaler om, hvordan individuelle elever bedst håndteres, og samtidig er der et hensyn til den samlede gruppe, som må tages. Alle ansatte må forholde sig til både den individuelle elev, som der arbejdes med og samtidig til den samlede gruppe. Og det er altid uforudsigeligt, hvordan det i praksis viser sig, at eleverne har det, hvornår de trives og hvornår de har brug for særlig opmærksomhed. Om de har en god dag eller en dårlig dag. Det, som lærere og pædagogmedhjælpere gør sammen, må med andre ord hele tiden justeres og ændres i relation til individuelle elever og i relation til klassens fællesskab. Det er tydeligt, når der observeres at se, at ansatte hele tiden afstemmer med hinanden om, hvem der gør hvad. Det er en måde at afstemme med hinanden, som er ordløs. Det er sjældent, at der tales direkte om det, ud over små spørgsmål og meddelelser.

Her et eksempel på, hvordan det at arbejde individuelt kalder på en relationel kompetence og en kompetence til at motivere og engagere elever med udgangspunkt i en respekt for elevens grænser, men også med en insisteren på, at det er et mål med skolen, at man skal lære noget.

\section{Motivation gennem relation:}

Pædagogmedhjælperen arbejder med en dreng 1:1. Drengen har et meget begrænset verbalt sprog, så de kommunikerer med kropssprog og tegnsprog. 
Arbejdsopgaven, som de arbejder med, er udviklet $i$ samarbejde med talepxdagog og har som et mål, at styrke drengens verbale sprog. Drengen er meget svær at fastholde $i$ aktiviteten. Han bevæger sig vak fra bordet og sidder meget uroligt. Pædagogmedhjælperen bruger humor til at få ham til at fokusere, og hun bruger meget stærk blik-kontakt og meget tydelig kommunikation. Den humor, hun bruger, er ikke sådan en humor, som skaber afstand til alvoren $i$, at drengen skal arbejde. Efter lidt forhandling og en masse sjov, sætter drengen sig ved bordet. Dvs. han sætter sig på sin stol, som står væk fra bordet. Pædagogmedhjælperen hiver stolen ind til bordet ved at bruge sine ben. Det ser drengen ud til at more sig over. Drengen kigger over på mig, og han rykker sig lidt væk fra bordet. De går i gang med at arbejde. At træne ord og vokaler. Da de er fxrdige med den opgave, skal de lave en ny opgave, som pædagogmedhjælperen henter frem fra drengens hylde. Drengen brokker sig med høje lyde, hvor ordet 'nej' synes at vare gennemgående. Han fär at vide, at de skal rykke tættere sammen. En forhandling starter igen om, hoor tæt de skal sidde på hinanden. Der er kontakt og smil imellem den, mens de rykker frem og tilbage på stolene. Pædagogmedhjælperen holder fast $i$, at der skal arbejdes, og det ender da også med, at de arbejder et stykke tid. Drengen fär en masse opmuntring og ros, når han løser opgaverne rigtigt. Ord som kontakt, relation, humor, eftergivenhed, rummelighed og insisteren synes at være vigtige elementer $i$, at det lykkes at få drengen til at arbejde.

Pædagogmedhjælperen i dette eksempel trækker på en praksisviden eller det, som Bourdieu kalde ren praktisk sans for, hvad der er rigtigt at gøre her og nu. Det er en helt central viden i relation til det arbejde, som består i at gribe elever, at møde eleverne, at motivere eleverne og at skabe en relation, som gør det muligt at etablere et læringsrum. Det er en kompetence, som man ikke kan læse sig til, men en kompetence, som kommer af en relationel kompetence, som er erhvervet i livet. Som pædagogmedhjælperne selv udtrykker det i interview, trækker de fx på det at have en bror med funktionsnedsættelse, at have arbejdet $i$ børnehave og vuggestue og at være et medlem af en stor søskende flok. Pædagogmedhjælperne definerer selv deres kompetence, som en relationel kompetence og en social kompetence. Og med ovenstående eksempler og relateret til en procesdidaktisk forståelse er det en ganske betydningsfuld kompetence - om ikke andet i det specialpædagogiske arbejde.

\section{Samarbejdet i praksis og samarbejdet om praksis}

Ud over ovenstående analyse af samarbejdet, som bygger på observationer er lærere og pædagogmedhjælpere fra alle team blevet interviewet om deres sam- 
arbejde. De er blevet spurgt direkte ind til, hvordan de forstår deres samarbejde - hvordan de samarbejder omkring planlægning, udførelse og evaluering af det specialpædagogiske arbejde. Herfra vil lærere og pædagogmedhjælperes egne fortællinger om deres samarbejde bliver formidlet. Analysen er fortaget på den måde, at interviewmaterialet er blevet kategoriseret i følgende kategorier: Planlægning, pædagogmedhjælperes deltagelse på møder, ændring og justering af planer og evaluering. Derfra er der valgt et snit i formidlingen, som organiserer empirien i kategorierne; planlægning, udførelse og evaluering af arbejdet.

\section{Planlægning}

Det er små variationer i forhold til, hvor detaljeret, de forskellige team planlægger og tilrettelægger det specialpædagogiske arbejde. I nogle team peger man på, at planlægningen er strengt nødvendig og beklager sig en smule over, at de ikke får planlagt godt nok.

- Overordnet laver vi en plan. Jeg synes ikke vi har gjort det godt nok. Vi kunne have planlagt det bedre

- Hvis der ikke var lavet en plan, så gik det ikke

- Grundlæggende har vi sørget for, at nogle elever hele tiden har en voksen på sig Det gør, at vi kan få klassen til at fungere bedre. Vi har en grundstruktur, der kan fungere.

I andre team er man mere bevidst om, at der må planlægges, men samtidig tales der om de uendelige ændringer og justeringer, som hele tiden må laves af planerne.

- Vi har en grundplan, hvem arbejder med hvem og med hvilket emne. Men den kan ændre sig, hvis nogle er syge eller skoleinspektøren henter personale hos os, men vi har altid en plan

- Vi planlægger overordnet en fordeling af elever, for at have tjek på sikkerheden, men derfra improviserer vi

- Vi har planer, men vi afviger fra planen, sådan at vi imødekommer de ting, som opstår for enkelte elever

- Vi har en Plan A og en Plan B

- Vi kan godt planlægge en dag, og det gør vi i en uendelighed, med skemaer og aftaler, men tit er der jo sygdom, og tit er der elever, der ikke er der, eller der kan være forskellige ændringer i planerne, fysioterapeuter, som henter børnene på anderledes tidspunkter. Der er altid forrykkelser i forhold til det, vi sådan oprindelig planlægger. Så der skal være noget, der hedder Plan A og Plan B og Plan Z, men der er rigtigt mange ting 
som er fastlagte på forhånd. Og på det ugentlige skoleplanlægningsmøde laver vi simpelthen et ugeskema, som vi lægger ud til forældrene, og vi ved, de ved også godt, hvad der ligger i de enkelte timer, så skriver vi lidt om, hvad det er vi laver, alt efter hvilket emne, vi arbejder med.

Et team er meget bevidst om, at de netop ikke er så detaljerede med planlægningen, og det er en samarbejdsform, de har valgt, og som de trives med.

- Vi er ikke så strukturerede, men det fungerer meget godt

- Vi finder stille og roligt ud af det

- Vi overtager for hinanden i situationen, vi fordeler roller, når vi er der

- Man behøver ikke at have et skema

\section{Udførelse og justering af planer}

Det er et gennemgående fænomen, at underordnet, hvordan teamet har truffet beslutninger om planlægning, må de alle forholde sig til en række uforudsete hændelser angående den overordnede planlægning af rollefordeling og også planer for undervisningen af enkelte elever. Det er et vilkår, som alle team meget opmærksomme på.

- Jeg synes, vi er gode til, når vi møder ind og ser, at der mangler nogle, så snakker vi lige om, hvad vi så kan gøre - uden at der er nogen panik. Vi fortvivler ikke

- Når man ser hvor mange, der kommer om morgenen, om alle møder på arbejde, så bliver der nok lige sagt, hov vi mangler en her, kan vi lige rykke lidt rundt på nogle ting

- Det er som i undervisningen. Du kan godt begynde på et eller andet, men så går det i en anden retning, og så må du jo følge barnet derhen, hvor det selv vil

- Du kan faktisk også være udsat for, at selv når du har forberedt noget om morgenen, lige sådan hurtigt, så bliver du lige pludselig nødt til at forberede faktisk noget andet, lige netop lige omkring en bestemt elev, for det går ikke den vej, du havde tænkt dig, så må du hurtigt lave en anden plan.

Disse udsagn falder godt i tråd med begreberne 'situeret professionalisme', 'praktisk sans' og 'procesdidaktik'. Der er en bred anerkendelse af, at det at arbejde specialpædagogisk forudsætter en evne til fleksibilitet og løbende tilpasning af planer til uforudsete hændelser. De ovennævnte udsagn viser specifikt hen til Uljens ide om in-situ-planlægning og evaluering og altså den løbende 
planlægning og evaluering i situationer. Dette vilkår for lærere og pædagogmedhjælpere i det specialpædagogiske arbejde kalder, som det har været en tese i undersøgelsen, på en særlig form for samarbejde i og om praksis, som lærere og pædagogmedhjælpere sætter ord på.

- Det drejer sig om at få tingene til at glide i hverdagen

- Humor er vigtigt i det her job

- Samarbejdet er godt, fordi vi kender hinanden så godt

- Vi laver aftaler hurtigt hen over bordet

- Vi samles lige sådan hurtigt, når vi må ændre i løbet af dagen - ellers har vi vores teammøder

- Meget af det her aftales egentligt ikke med sprog, det er meget vi bare gør

- Vi skal bare kigge på hinanden, så ved vi, hvad vi skal gøre

- Det kan også være, at en kollega har været sammen med det samme barn for længe, og det her barn er fuldstændig oppe og ringe, og man bliver nødt til at sige; hey nu kan jeg godt se, nu er det noget lort, skal jeg ikke lige gå ind og tage den.

Det viser sig med disse formuleringer, at teamene har indarbejdet en fast rutine eller en implicit definition af situationen, sådan som Goffman definerer evnen til at vide med hinanden i et arbejdsfællesskab, hvordan situationer tackles og hvem der gør hvad - og det er et ikke verbaliseret system af aftaler, som fungerer i praksis.

\section{Evaluering}

Når de forskellige team bliver spurgt om deres evalueringspraksis, tegner der sig et broget billede. Nogle team evaluerer systematisk, mens andre team ikke når dertil i deres praksis.

- Vi er ikke så gode til at evaluere - vi skal så mange ting, så vi mangler at fordybe os

- Bare det at lave den fælles undervisningsplan, den er jo ikke ordentlig fælles, og derfor bliver evalueringen ikke fælles. Det kan ikke være rigtig, siger jeg, men jeg kan ikke selv få det til at fungere

- Evalueringen foregår på teammøder, men er ikke formaliseret, og det burde den være

- Vi skrev i et referat, at vi skulle være bedre til at evaluere, men vi får det ikke gjort. Der opstår en god snak og vi når noget, men det er ikke formaliseret 
- Vi er ikke gode til at være formelle, men der kommer mange ting på bordet og nye ideer, og alle kan melde ind på noget. Det kan også blive for stift

- Jamen, når man står i situationen gang på gang på gang, og det er bare noget lort, så bliver man jo nødt til at smide det hele op i luften og gribe de bolde, som kommer ned til en altså. Hvor er vi nu, og hvor ender vi det prøver vi

- Vi har jo teammøder fast en gang om ugen, hvor skoleteamet mødes, men vi mødes også en gang om ugen hvor vi har SFO'en med indover . Og det er der, hvor vi diskuterer og evaluerer

- Det er tit noget, som vi klarer efter arbejde. Så mødes vi lige heroppe i fem, ti minutter, sidder lige og snakker stille og roligt, hvordan er dagen i dag gået, det var sgu noget rigtigt lort altså, ja, og så videre

- Når vi har Skole-SFO teammøde, som vi kalder det, så snakker vi alle børnene igennem, kan man sige. Vi snakker lidt om, hvor er de og hvordan synes vi, de rykker, og er der nogle steder, hvor vi skal støtte dem noget mere, er der nogen af dem måske, der har lidt vanskeligheder lige i øjeblikket, som vi skal hjælpe dem med.

Det er tydeligt, at den løbende evaluering i situationen, knyttet tæt til den daglige praksis, er en evaluering, som skolen arbejder med, men den mere formaliserede evaluering, synes ikke at være en indarbejdet samarbejdsform.

\section{Opsamling}

Pædagogmedhjælpere har en central kompetence, som knytter sig til undervisningen. De trækker på praksisviden, som kan beskrives som en sans for, hvad der er rigtigt at gøre her og nu. Det er en viden, som består i at have blik for eleverne, at kende eleverne godt, at gribe elever, at møde eleverne, at motivere eleverne og at skabe en relation, som gør det muligt at etablere et læringsrum. Pædagogmedhjælperne definerer selv deres kompetence, som en relationel kompetence og en social kompetence, som en betydningsfuld kompetence i undervisningen på en specialskole.

\subsection{Det tværfaglige samarbejde på teammøder med flere fag- grupper}

$\mathrm{Nu}$ vil de observerede team-møder mellem pædagoger, lærere og pædagogmedhjælpere bliver analyseret. På møderne indgår forskellige faggrupper på et fast ugentligt møde mellem lærere og pædagoger og pædagogmedhjælpere. Ud over disse faggrupper har der på tre af de seks team-møder været besøg af for- 
skellige konsulenter: En psykolog, en Pecs-konsulent og en LP-konsulent ${ }^{12}$. Feltnotater fra team-møder udgør derfor en interessant empiri i forhold til at analysere, hvordan det tværfaglige samarbejde praktiseres, og hvordan den fælles definition af situationen (Goffman) og/eller en fælles kulturel enighed om formål (Barth) kan defineres og bliver defineret på team-møder.

Analysen vil blive delt i to områder. A) Første del vil fokusere på den fælles definition af situationen, og/eller den fælles kulturelle enighed om formål vil blive fremanalyseret, som viser sig på den ene side at være stærkt informeret af specialiseret viden og på den anden side at være informeret at den praksisviden og kundskab, som lærere, pædagoger og pædagogmedhjælpere trækker på i den daglige praksis, og som rapporten har indfanget fra forskellige vinkler. B) Anden del vil fokusere på pædagogmedhjælpernes deltagelse i møderne. Det viser sig, at pædagogmedhjælperne og i nogen udstrækning pædagogerne bliver udgrænset i de møder, hvor den specialiserede viden, via konsulenter, er på dagsordenen, mens pædagogmedhjælpere inddrages og bidrager, når møderne angår den pædagogiske og didaktiske praksis i hverdagslivet.

\section{A: Den fælles situationsdefinition og enighed om faglige formål}

I det specialpædagogiske område (se Tetler, Baltzer, Hedegaard-Sørensen, Boye og Liv Andersen. I: Egelund \& Tetler (2009)) kan det specialpædagogiske område - og måden det er organiseret på - problematiseres i forhold til den store indflydelse, der gives til en specialpædagogisk vidensbase, der lægger et entydigt fokus på specialiseret viden, som specialpædagogikken oprindeligt er tæt forbundet med. Specialpædagogikken har sine rødder i det psykologiske og medicinske fagkompleks og $\mathrm{i}$ antagelsen om, at det gavner elever at sætte ind med en specifikt indrettet kompensatorisk indsats ud fra en definition af elevers medicinske og/eller psykologiske diagnoser. Det specialpædagogiske område er organiseret sådan, at specialiseret viden og afgrænsede behandlings- og undervisningsprogrammer, tilbydes lærere. Også på den specialskole, hvor denne undersøgelse om roller og samarbejdsformer har fundet sted, indtager forskellige specialiserede faggrupper rollen som dem, der vejleder lærere, pædagoger og pædagogmedhjælpere i at tilrettelægge undervisningen. Der er psykologer og andre konsulenter fx Pecs-konsulent tilknyttet skolen. Der er derudover tilknyttet en IT-konsulent og en LP-konsulent. Disse specialister og konsulenter inviteres af lærere til team-møder og på baggrund af særligt lærernes fortællinger om eleven i undervisningssituationer vejledes lærerne $i$ at benytte de forskellige metoder i deres undervisning. Antagelsen er, at forskellige kompensa-

${ }^{12}$ LP-metoden er en metode, der støtter en analyse af praksis ud fra et læringsfokus og et pædagogisk fokus. 
toriske metoder tilbydes dem, som arbejder med eleverne i praksis og at lærere, pædagoger og pædagogmedhjælpere skal implementere/overføre disse metoder til deres praksis.

Pointen i den efterfølgende analyse er, at lærere, pædagoger og pædagogmedhjælpere også på denne skole tilbydes specialpædagogisk konsulentbistand og at konsulenterne rådgiver dem, der arbejder i praksis, men på møder, som er løsrevet fra den konkrete praksis. Der eksisterer altså i det specialpædagogiske område - og også på den skole, hvor der er blevet produceret empiri i forhold til at forstå roller og samarbejdsformer - en strukturel/organisatorisk opdelingen mellem undervisning i praksis på den ene side og specialiseret viden, som er løsrevet fra praksis på den anden side. Der er talepædagoger ansat på skolen, som også vejleder lærere (og andre faggrupper) $i$ at forstå elevernes kommunikationsvanskeligheder. Talepædagoger indgår på en mere integreret måde i relation til specialpædagogisk praksis. De har et tæt samarbejde med lærere (pædagoger og pædagogmedhjælpere) omkring tilrettelæggelsen af undervisningsmetoder, hvor fokus er på kommunikation.

Som det vil fremgå af de efterfølgende analyser tyder noget på, at en problematisering af konsulenternes rolle i forhold til at tilføre lærere og andre faggrupper viden er relevant $\mathrm{i}$ indeværende empiriske undersøgelse (se også Hedegaard-Sørensen (2010a), Tetler m.fl. (2009)). Det specialpædagogiske felt er organiseret sådan, at lærere, pædagoger og pædagogmedhjælpere arbejder i praksis, mens konsulenter rådgiver om praksis, men løsrevet fra den situerede praksis. Der ligger i en sådan organisering en antagelse om, at specialiseret viden kan overføres fra en kontekst (et møde, hvor en elev diskuteres) til en anden kontekst, som er konkrete undervisningssituationer, hvor konkrete og situerede problematikker udspiller sig. Som det vil fremgå af de empiriske analyser, synes der at opstå et sammenstød mellem viden fra forskellige kontekster på møder med konsulenter. Der synes at opstår en konflikt eller en modsætning imellem den måde, der snakkes på og samarbejdes på på møder med eksterne konsulenter, og den måde der snakkes på og samarbejdes på på møder uden eksterne konsulenter. Noget tyder på, at der udspiller sig et sammenstød, en konflikt eller modsætning mellem den viden og de kundskabstraditioner, som udspiller sig i praksis og i tid og sted og den viden og den type kundskab, som konsulenter tilbyder. Den negative utilsigtede konsekvens er, at den specialiserede viden, som der kan være brug for i specialpædagogisk arbejde, ikke kommer til at gøre nytte i det specialpædagogiske arbejde. Altså at den specialpædagogiske praksis defineres entydigt ud fra en almendidaktisk og almenpædagogisk forstålseshorisont og ikke i relation til de funktionsnedsættelser, som eleverne har og de behov for kompensatoriske tiltag, som funktionsnedsættelserne forudsætter. 
Den specialpædagogiske viden - eller den specialiserede viden om elevers diagnoser og behandlingsprogrammer og metoder, der kompenserer for disse bevæger sig ind i området for strukturering af undervisningsrummet, sådan som især Teacch-programmet tilbyder struktureringer. Den specialiserede viden tilbyder ikke viden om, hvordan undervisningen bedst udføres, og hvordan den tilpasses elever med funktionsnedsættelser. Fx hvordan elever motiveres (ud over at struktur menes at skabe ro og motivation), hvordan elever engageres, hvordan undervisningsindholdet tilpasses elevernes interesser og forudsætninger osv. Jævnfør Hiim og Hippes didaktiske relationsmodel, som bidrager med en teori ind i dette felt. Derudover, som det er fremgået tydeligt af denne undersøgelse, kalder det pædagogiske og didaktiske viden på en kompetence til at håndtere uforudsete hændelser $\mathrm{i}$ teamet og i den konkrete undervisning, som den specialiserede viden heller ikke er egnet til at adressere. Den specialiserede viden kan ikke tilbyde viden om den komplekse praksis, som udfolder sig i tid og sted. Den kalder på en praksiskundskab og en situeret professionalisme, som er en anden form for professionalisme, end den, hvor programmer, metoder og modeller overføres til praksis.

\section{Team-møderne imellem to kundskabstraditioner}

David Polkinghorne (2004) skelner mellem techne og pronesis. Den specialiserede viden kan betegnes som techne i den forstand, at det er en universel viden fx om diagnoser og behandlingsprogrammer, som er knyttet til diagnoserne. Det er en viden, som gælder for alle, der har samme diagnose, og de behandlingsprogrammer, den foreslår, er også universelle i den forstand, at alle med en bestemt diagnose antages at have brug for en bestemt metode. Derudover er techne som en form for viden kendetegnet ved, at den antages at kunne overføres til alle praksisser. Modsætningen hertil defineres som pronesis. Og den kundskab, som pronesis betegner, er den praktiske kundskab, som lærere, pædagogmedhjælpere og pædagoger anvender i deres praksis og som ikke i udgangspunktet er teoretisk. Den er en viden, som kan beskrives om improvisation, vurdering, skøn, og det er en viden som er situeret i mennesker (professionelle) og i situationer. Det er en viden, som ikke er universel - og gældende for alle. Derimod er antagelsen, at enhver situation er unik og finder kun sted en gang. Derfor må den professionelle være parat til at fortolke og skønne på ny i alle situationer. Ikke bare situationer er unikke. Det er individer også. På trods af diagnosen inviteres til, at elever skal mødes på en anden måde end ud fra deres diagnose. De skal mødes ud fra deres måde at agere på og på deres unikke personligheder. Der findes ingen universelle tilgange eller opskrifter for, hvordan det gøres. 
I analysen af team-møder bliver det helt tydeligt, at der i den faglige kultur (situationsdefinitioner og fælles enighed om formål) er de ovenstående to kundskabstraditioner i gang på samme tid. De udgør tilsammen den vidensbase, som alle fagpersoner taler sig ind i. Men det er ikke nødvendigvis to videnstraditioner, som de forskellige faggrupper er bevidste om, ikke sådan uden videre lader sig forene. På trods af de forskelle, der er på de to traditioner, synes dialogen at blive opretholdt uden en problematisering. Der eksisterer en stiltiende accept hos alle om, at det giver mening at holde et møde om Pecs, LP og psykologisk viden omkring håndteringen af et barn. Her nogle eksempler på, hvordan dialogen føres og på, hvordan modsætninger overkommes.

\section{Psykologen}

Det første møde, der vil indgå som eksempel er et møde om et bestemt barn, som en psykolog skal rådgive lærere, pædagoger og pædagogmedhjælpere om. Psykologen definerer mødet som et 'rådgivende møde og ikke et planlæggende møde'. Altså, et møde, som drejer sig om, at psykologen skal tale med en piges lærere, pædagoger og pædagogmedhjælpere, fordi pigen skal re-testes, og psykologen har brug for at finde frem til, hvilken test, hun skal lave. Pigens kontaktlærer har en anden intention med mødet. Hun siger: 'Vi har bedt dig om at komme, fordi vi har brug for et råd'. Der er altså to dagsordener i gang på samme møde. Psykologen er interesseret $\mathrm{i}$ at re-teste, og læreren er interesseret $\mathrm{i}$ at få viden om, hvordan pigen skal tackles i hverdagen.

Læreren siger efterfølgende: 'Vi har fulgt dine råd. Vi har piktogrammer med billeder, og det har skabt meget ro, men da vi var på tur, gik det galt. Så tog vi skemaet op igen og det hjalp. Vi har gjort det, at vi har ekskluderet hende fra morgensamling, men vi er begyndt at inkludere hende igen'. Teamet har fået nogle konkrete metoder, men disse metoder synes at skride i hverdagens praksis. Der er en antagelse om, at de råd, de har fået har hjulpet, og der er ingen problematiseringer af rådene og metoderne.

Derfra går der en samtale i gang om pigen. Især pigens kontaktlærer (men også en pædagog) fortæller om pigen. Hun siger: 'Hun koster rundt med alle', 'Vi har brug for hendes kognitive status', 'hun har et fint sprog, men hun kan ikke spørge', 'hun har svært ved at koble tanke og ord', 'hun kan rigtig meget, men hun kan ikke lave tegn', 'hun er smadder kreativ', 'hun har svært ved at slippe ting', 'jeg tænker, hun er træt', 'hun har godt af at lave ingenting'. Når pigen bliver beskrevet er det ud fra en mangfoldighed af perspektiver. Nogle angår pigens funktionsevne, andre hendes reaktioner i situationer og andre hendes hjemmeliv.

På baggrund af de ovenstående fortællinger, rejser psykologen sig op, går hen til en tavle og holder et oplæg, som starter med følgende sætning: 'På bag- 
grund af det, I siger, kan vi konstatere, at hun har nogle reguleringsproblemer'. Psykologen fortæller om at være opgearet og at være slukket; altså at have forskellige arousal-niveauer. Psykologen råder teamet til at give pigen passende stimuli. Ikke for mange og ikke for få. Teamet kommer med forskellige udsagn, som går imod psykologens oplæg, men de inddrages ikke. Psykologen fortæller, at pigen har brug for ro og struktur, for hun bliver forstyrret af lyde. En lærer taler om, at pigen synes at have brug for skift også i undervisningssituationer. Psykologen stopper refleksionen og siger, at det vil hun vende tilbage til, når pigen er testet. Hun gennemgår nogle forhold omkring hjerneskade og læring og peger på, at pigen har brug for, at det samme bliver gentaget igen og igen.

Samtalen fortsætter sådan i lang tid. Den er kendetegnet ved, at lærere (især), men også pædagoger og i meget ringe grad pædagogmedhjælpere fortæller om deres iagttagelser af pigen, og psykologen formidler viden om hjerne, læring og perception. Det er et glimrende udtryk for modstillingen mellem kundskabstraditioner. Psykologen slutter mødet af med at sige: 'Tænk over det og se om noget af det, som jeg har fortalt, kan omsættes i en ny praksis'. Altså, antagelsen er, at teamet kan omsætte nogle af disse metoder i praksis.

\section{Pecs-konsulenten}

Mødet med Pecs-konsulenten starter med at en pædagog viser en film, hvor hun træner kommunikationsprogrammet Pecs med en pige. Mødet drejer sig om, at konsulenten skal støtte teamet $\mathrm{i}$ at arbejde med Pecs. Filmen handler om, at pigen skal vise, at hun vil have yoghurt, og når hun har peget på et billede af mad, får hun en skefuld Danone-yoghurt. Konsulenten konstaterer, at pigen får for mange valg, og at hun skal lære at vente. Hun foreslår et ventekort, dvs. et billede, som signalerer vente, som den, der træner hende, skal have med. Læreren siger, at hun er i tvivl om, hvad hun skal gøre, når pigen vælger det forkerte. Pecs-konsulenten kigger i sin manual. Mens hun kigger i manualen, snakker teamet om, at de har sprunget en masse faser over, som Pecs-programmet ellers foreskriver. Konsulenten konkluderer hurtigt - efter at have kigget i manualen - at de skal finde ud af, hvilke billeder, som er væsentlige og vælge de andre fra. Altså, reducere i kompleksitet. De snakker om hvordan og hvem, der skal træne med pigen fremover. En lærer siger, at det bliver nødt til at foregå i klassen. Konsulenten responderer: 'Det er godt at få den træningsagtige situation lidt afløst af mere naturlige situationer'. De snakker frem og tilbage om, hvordan manualen foreskriver træningen. Konsulenten siger for sjov, at hun lige vil slå op i manualen. En lærer siger: 'Man skal jo også få det til at fungere i virkeligheden'. Konsulenten siger: 'Ja, så religiøs er jeg heller ikke'. Konsulenten 
trækker mødets råd til teamet op, og mødet slutter. Teamet fortsætter med at holde almindeligt team-møde.

Her et eksempel på, at både konsulent og team forholder sig til forholdet mellem den kunstige træningssituation og den mere naturlige situation i hverdagslivet i skolen. De joker lidt med det, men går ikke ind sammen og problematiserer, at det er en meget unaturlig situation, at en pige tages ud af klassen og trænes. Dog er det en fælles ambition at gøre det så naturligt som muligt. Der er altså igen gang $\mathrm{i}$ to forskellige kundskabstraditioner og to forskellige virkeligheder - den kunstige, kompensatoriske træningssituation og de situationer, som opstår i klassen. Her tager den konsultative bistand afsæt i en praksissituation, men som det vil være fremgået, ender mødet med at dreje sig om, hvordan metoden kan omsættes i praksis, frem for i en refleksion over metoden i praksis.

\section{LP-konsulenten}

LP-mødet er meget kort, fordi teamet vælger at gøre det kort. De har så mange andre ting, som de har brug for at snakke om på team-mødet. LP-modellen er tænkt som en metode til at reflektere over og ændre læringsmiljøet og ikke udelukkende at fokusere på eleven og elevens deficit. Derimod på samspillet mellem elevens deficit og omgivelserne, som er de pædagogiske og didaktiske tilrettelæggelser. Teamet har udfyldt et skema omkring forskellige omverdensfaktorer for en bestemt pige, som de har fokus på. De bruger mødet til at evaluere de beslutninger, som blev truffet på sidste LP-møde. Det viser sig, at de kun har arbejdet med en af de fire omverdensfaktorer, som de besluttede før. De har anskaffet pigen høreværn, så hun bliver beskyttet for uro. De andre har de ikke nået, siger de. LP-konsulenten foreslår, at de går i gang med de andre tre omverdensfaktorer. De ender med at aftale, at de kun har tid til en af dem. De vælger at begynde at arbejde med en talemaskine sammen med pigen. LP-punktet slutter og teamet fortsætter med at holde et almindeligt team-møde.

LP-modellen er tænkt, som et redskab, der sætter fokus på analyse af den kontekst elever er i, men det viser sig på dette møde, at omverden bliver tolket som kompensatoriske og/eller støttende metoder. LP er en metode i forhold til at sætte fokus på praksis, men det viser sig på dette møde, at praksis ikke kommer i tale.

\section{Kulturel enighed om formål og fælles situationsdefinition}

Opsamlende kan eksemplerne fra team-møderne med konsulenter illustrere, at de to forskellige kundskabstraditioner fungerer side om side. Der er en fælles enighed om, at det giver mening at arbejde specialpædagogisk ved at trække på 
specialiseret viden og samtidig er det tydeligt, at teamet forsøger at give noget, der ikke sådan umiddelbart giver mening ind i deres praksis, mening. Teamet forsøger at forene de to traditioner, og som det er fremgået, er der på skolen en meget stor dominans af forskellige metoder fra den specialiserede vidensbase, som teamene har valgt at arbejde med, og som de integrerer i deres daglige praksis. I den observerede praksis, synes der ikke at være så store vanskeligheder med at forene og integrere. Dette fordi undervisningen i vidt omfang bliver tilrettelagt, som træning af funktioner, samtidig med, at der lægges vægt på, at det at gå på en skole er en ret, som børn og unge har. En ret til at opnå venskaber ved at være sammen med jævnaldrende i nogle sociale sammenhænge.

I en samtale med to lærere under observationerne fremgik det netop, at det står meget centralt for dem, at børnene går i skole. Altså, får den oplevelse, som alle børn skal have af at gå i skole og have kammerater og blive mødt med forventninger om, at indgå i et fællesskab med andre. Det at gå i skole, som fænomen, og helst så klassisk som muligt, er en værdi for sig selv. De nævner selv ord som socialisering og normalisering, der ligger i at gå i skole ligesom alle andre. I en snak med en anden lærer kommer det tydeligt frem, at den fælles faglige kultur på skolen forener specialiseret viden og den daglige praksis i klasserum. Læreren fortæller mig, at hun oplever, at 'lærer- og pædagogarbejde blander sig sammen på skolen'. Læreren forsøger hele tiden at finde læringen i alt, hvad hun foretager sig, fortæller hun. Fx når hun spiller bold med eleven, der har brug for fysisk aktivitet, må hun tænke, at han jo bliver bedre til at gribe, og derfor er det læring. Hun pointerer, at relationsarbejdet fylder rigtig meget. Hun siger, at man må skabe relationer, som en forudsætning for at kunne skabe læring. Hun fortæller, at hun tidligere var på Brøndager-skolen og der lærte en masse om Teacch, som hun bruger i dag. Hun fortæller, at hun mener, at eleverne har brug for 1:1, hvis de skal lære noget, men hun oplever, at der ikke er lærerressourcer nok til det.

Den fælles kulturelle enighed om formål og den fælles situationsdefinition er, at det er muligt i praksis at forene kundskabstraditioner.

\section{B: Pædagogmedhjælperes deltagelse på team-møder}

Det er en klar tendens i team-møderne, at pædagogmedhjælperne på den ene side er fuldt integreret $\mathrm{i}$ det faglige fællesskab og bidrager på møder med input på linje med andre faggrupper, men det står lige så tydeligt frem, at når møderne drejer sig om specialiseret viden, hvor konsulenter indgår, så skrives pædagogmedhjælperne ud eller skriver sig selv ud. De bliver til tilskuere på møderne, mere end til deltagere. Det er også en tendens, at pædagogerne i nogen udstrækning synes at være lavere placeret i hierarkiet end lærere på disse møder. 
Det er som om møder om specialiseret viden og læring og undervisning udgør kernefagligheden, som specialskolens faglige fællesskab sætter højt. Og til denne kernefaglighed udvises der respekt og ydmyghed hos lærere i forhold til konsulenter, og hos pædagoger i forhold til lærere og konsulenter, og hos pædagogmedhjælpere over for de uddannede faggruppers viden og kompetence. Når møderne ændrer sig til almindelige team-møder uden eksterne konsulenter, og når talen kommer på planlægning og evaluering af den daglige praksis, kan man derimod opleve, at pædagogmedhjælpere er eksperter og tager lederskab og ansvar - og det i højere grad end lærere.

\section{Pædagogmedhjælpere skrives ud}

Når feltnotater fra team-møder analyseres med henblik på at undersøge, hvem der har ordet og deltager, så er der en påfaldende tavshed hos pædagogmedhjælperne, når møderne har eksterne konsulenter med.

På tre af de seks team-møder var der, som nævnt, besøg af ekstern konsulent. På to af disse møder, var møderne delt op, sådan at den første del var et møde om en metode (Pecs) eller med en LP-konsulent omkring et specifikt barn, og den anden del af mødet kan beskrives som et almindeligt teammøde. På de to møder var der et påfaldende skift i pædagogmedhjælpernes deltagelse og deltagelsesmuligheder. Når mødet kommer til fx at handle om børn generelt - dvs. børn i den daglige praksis - eller planlægning og evaluering af en lejrtur, træder pædagogmedhjælperne ind med kompetente bidrag og med stor indsigt.

Her følger et eksempel på, at det ikke udelukkende er pædagogmedhjælperens eget individuelle ansvar, at det er svært at få taletid på møderne, når konsulenterne er til stede. Mødet drejer sig om Pecs-metoden i forhold til et bestemt barn. De, der taler på mødet er i omfattende grad to lærere og Pecs-konsulenten. Pædagoger og pædagogmedhjælpere bidrager kun ganske lidt, og det viser sig, når mødets dialog analyseres, at både pædagogers og pædagogmedhjælperes bidrag ignoreres eller afvises eksplicit.

På mødet diskuteres det, hvilke billeder til Pecs-træningen, som er relevante for pigen, i forhold til at integrere Pecs-træningen i 'mere naturlige omgivelser' og situationer i klasserummet. Dvs. hvad er det for et liv, pigen har i klassen, og hvor er hendes behov og interesser i forhold til at blive støttet i at kommunikere? Hvad skal der kommunikeres om? Eller hvad skal prioriteres, for det er slået fast, at der skal reduceres i kompleksitet for pigen. Talepædagogen på skolen er med til mødet og går ind og bidrager. Herfra er dialogen som det følgende:

Talepædagog: Jeg synes, vi skal støtte hende $i$ at sætte ord på, hoad hun selv vil. Hvad er det, hun selv gerne vil? 
Pædagog: Hos os er det forskellige aktiviteter, som hun vælger.

Ingen responderer på det, som pædagogen siger. Konsulenten siger ' $j a^{\prime}$ på en uengageret måde og kigger i sine papirer (manual). Der er en lille pause, indtil taleprdagogen tager ordet.

Talepædagogen: Jeg mener, hun er der i sin sproglige udvikling, hoor hun.......

Konsulenten: Jeg synes, at det I skal gøre er at vælge nogle fä billeder og træne dem med hende, $i$ et lokale vak fra klassen, og når I er fortrolige med det, så kan I trække det ind $i$ klasserummet.

Pædagog: Men har vi nogle lokaler, hvor det giver mening at gå hen, og har vi tid til at gå fra med hende?

Pædagogen ignoreres, og der opstår igen en lille pause.

Konsulenten: Hvor mange lærere har hende til Pecs.

Eksemplet taler for sig selv. De, der er inkluderet i samtalen/dialogen omkring denne pige og Pecs-træning, er konsulenten og to lærere. Det paradoksale er, at på filmen om et Pecs-træningsforløb, er det en pædagog, som træner pigen. Denne pædagog synes ikke - på trods heraf - at blive inkluderet. Det kan hænge sammen med, at hun skal være i en anden klasse efter sommerferien, som nærmer sig. Men det kan også være udtryk for et hierarki, et uddannelseshierarki, hvor pædagoger ikke positioneres højt.

Et andet eksempel er fra mødet med en psykolog omkring et bestemt barn, som skal re-testes. Det er et eksempel på, at en pædagogmedhjælpers bidrag afvises, på trods af, at pædagogmedhjælperen har stor erfaring med og indsigt om pigen. Samtalen udgøres på mødets start af, at pigens kontaktlærer fortæller, hvordan hun ser pigen, og konsulenten spørger ind. Der er ingen bidrag fra andre faggrupper her. På et tidspunkt spørger psykologen: 'Er der andre, som har lyst til at sige noget?', men ingen andre har lyst til at sige noget, og dialogen fortsætter. Da mødet har varet i ca. 45 minutter, er det kun lærere og konsulenter, der har haft ordet. Der har været et bidrag fra en pædagog, men ellers har der været helt stille omkring bordet. Mødet fortsætter og psykologen går til en tavle og holder et oplæg om høj og lav arousal. Og derfra opstår der en afvisning af et bidrag fra en pædagogmedhjælper:

Konsulent: Hvis man bliver meget forstyrret af lyde, så er risikoen, at man kommer højt op $i$ arousal-niveau. Hjernen skal helst mødes på et passende niveau - ikke for højt og ikke for lavt.

Lxrer: Det ender nogle gange med at blive meget vildt, når hun leger.

Konsulent: Det kan godt hænge sammen med, at hun bruger noget vildt, for at holde sit lave arousal-niveau væk - hun bruger fysisk aktivitet. Hvis hen- 
des bearbejdningsteknikker er hæmmet, så bliver det meget kaotisk for hende. Det er en hypotese, man kan også skifte aktiviteter.

Pædagogmedhjælper: Kan det hænge sammen med, at når hun spiller computer, så skifter hun program hele tiden.

Konsulent: Det tror jeg ikke har noget med det at gøre.

Lærer: Det er som om, hun har brug for at skifte. Sådan er det også med det faglige.

Konsulent: Det kan være for at sige, at nu gør vi det først på din måde, så gør vi det på min måde. Men jeg kan ikke sige mere om det, før hun er testet.

Eksemplet viser, at konsulenten ikke går aktivt ind, når pædagogmedhjælperen spørger, men det gør hun, når læreren kort efter spørger om det samme. Nu bare knyttet til det faglige. Det er et eksempel på, at pædagogmedhjælpere - og deres bidrag - ikke inkluderes på mødet som betydningsfuldt. Og det kan være en forklaring på, hvorfor der bidrages ganske lidt.

Derudover er det slående, at refleksioner over, hvordan pigen reagerer i konkrete situationer i undervisningsrummet eller i klasserummet bliver underordnet den viden, som psykologen venter af få fra en test af pigen. Den viden, som har højest status, bærer den, som i et uddannelseshierarki har højeste status. Eller mest 'kapital', som Bourdieu ville udtrykke det. Bourdieus teori om praktik vil kunne perspektivere et empirisk fund som ovenstående. I denne teori skrives det frem, hvordan mennesker positionerer sig for hinanden ud fra mængden af anerkendt kapital (viden og uddannelse). Det, som strukturerer hierarkiet på et møde som ovenstående er de sociale vilkår eller det større sociale rum, hvor der er forskelle i status, magt og indflydelse. Og i dette større sociale rum tillægges akademisk uddannelse og viden (psykolog) mere status end den viden, som en lærer repræsenterer og især end den mangel på viden og kapital, som en ikke uddannet pædagogmedhjælper repræsenterer. Den overordnede fordeling og opdeling af status i forhold til mængden af symbolsk kapital (viden, uddannelse og det, som anerkendes som værdifuldt i et felt) øver indflydelse på individerne, når der holdes møde; de enkelte individer kan ikke undslippe sig denne indlejring i det sociale.

\section{Det tværfaglige samarbejde på skolen}

I et interview fremgår det af en udtalelse fra en lærer, hvordan det tværfaglige samarbejde på skolen forstås. Der viser sig en tøvende accept af, at der er forskel på position alt efter uddannelsesniveau og status, men samtidig et ubehag, som er forbundet med det. Her citatet: 
Og det er en stor udfordring at skulle arbejde så mange faggrupper sammen. Pædagogmedhjælper, som er ufaglært, selvom at vi lige har siddet og blevet enige om, at hun rummer en utrolig stor værdi og viden rent menneskeligt, ... og jeg kom til at tænke på Bourdieu, tror jeg det er, der snakker om symbolsk vold, at vi er os vores uddannelser bevidst, og at nogen måske har mere at skulle have sagt end andre, symbolsk. Og hvis man er sig det bevidst, det bliver rigtigt spændende, fordi så kan man bedre overskue og bedre navigere i det og sige; jamen jeg har en faglighed, som lærer, pædagogerne har en faglighed som pædagoger, og Pernille har en faglighed som ufaglært. Som menneske og har tillært sig utroligt mange ting, altså er autodidakt på mange områder. Og hvis man får øje på den kunnen og er klar over, hvad det er, der er ens eget ansvarsområde, så kan man bedre udnytte de andres potentialer og derved få et nemmere samarbejde. Det er sådan rent teoretiske tanker og rent praktisk, og det kan være rigtigt svært.

Læreren fortæller med reference til Pierre Bourdieu, at der er forskel i mængden af symbolsk kapital, og at det påvirker samarbejdsrelationerne. Samtidig siger hun noget væsentligt om samarbejde, som en tese, der er integreret i den samarbejdskultur, som skolen er præget af. At det er centralt, at de forskellige faggrupper anerkender hinandens forskellige faglige udgangspunkter og accepterer, at der kan bidrages med forskellige roller og perspektiver ind i det tværfaglige samarbejde. Det er tydeligt, også fra empiriske analyser i denne undersøgelse at skolen i nogen udstrækning er lykkedes med i den daglige samarbejdspraksis at nå langt i forhold til ovenstående vision. Hun siger også, at det er svært, som møderne tyder på. Men det er værd at bemærke på det sidste møde-citat/uddrag, at det ikke er læreren, der skriver pædagogmedhjælperens bidrag ud som irrelevant. Læreren følger det op og siger faktisk det samme.

Et eksempel fra et team-møde, hvor pædagogmedhjælperes bidrag ind i det tværfaglige samarbejde vil herunder blive fremanalyseret. Som det er fremgået tidligere viser det sig, at pædagogmedhjælpere indtager og tilbydes en helt central rolle i relation til det specialpædagogiske arbejde i praksis. Og den anerkendes de for af lærere og pædagoger. Det viser sig, som det også er antydet før i rapporten, at pædagogmedhjælpere har en afgørende betydning for, at målet om undervisning kan realiseres, og at det tværfaglige samarbejde med lærere i nogen udstrækning forekommer at være langt mere uproblematisk end det tværfaglige samarbejde med pædagoger. Her et udsagn fra en lærer, som indfanger netop dette. 
Pædagogerne har jo nogle arbejdsområder, nogle indsatsområder, som de af deres leder bliver bedt om at gå ind og gøre i skoletiden. Så pædagogernes virke er ikke bare, i gåseøjne, at være pædagogmedhjælpere, at få stukket en opgave ud af os lærere. Vi sidder jo med den enkelte elev og skal holde elevplansmøder og status to gange om året med forældrene og er forpligtede på at holde forældremøde ligeledes; så det vi laver, det skal jo være en ensartet, sammenhængende masse, kan man sige. Så de mål vi vedtager, skal hænge sammen. Og man kan sige med den, den forholdsvis lille tid der er til at være meget fag-faglig, det man forstår ved at være skolefaglig, for vi ved godt, at der foregår noget fagligt, når man hjælper en elev på toilettet, kan du slukke lyset, kan du tænde for vandhanen, en mundtlighed, en guidning, en gøren selvstændig. Der ligger rigtigt mange ting der, men den der meget faglige med, at nu sidder du og jeg overfor hinanden, jeg er lærer, du er elev og nu skal vi lave nogle opgaver, den der sådan lidt mere skoletænkning, den er der ikke særlig meget tid til, fordi vi har mange praktiske opgaver som lærere også. Og hvis ikke vi har pædagogmedhjælperne og pædagogerne med på den opgave, så kan vi simpelthen ikke nå det i løbet af en skoledag. Når det fungerer allerbedst, så sidder vi på vores ugentlige Skole-SFO møder, hvor alle omkring børnene deltager, og fastlægger målene og finder ud af, hvordan skal vi rent praktisk nå frem til at nå de mål. Og så evaluerer vi; var det for højt eller var det for lavt skudt eller hvad var det? Eksempelvis kan en pædagog have et mål der hedder, at de skal sprogligt stimulere. Og så siger jeg, ja og hvor passer det så hen i min faglighed, hvad kan du byde ind med, og hvordan ser jeg det som mit mål, og så udarbejder vi, sagt meget fint, en opgave som vi sammen kan løse, på hver vores måde.

Læreren udtrykker, at samarbejdet med pædagoger og pædagogmedhjælpere er afgørende for, at det kan lade sig gøre, at opnå mål om læring. Hun siger også, at samarbejdet med pædagoger, som også har mål, forudsætter, at pædagoger og lærere sammen må diskutere og komme til en form for enighed om, hvilke mål der er for eleverne - brede mål og ikke udelukkende rent fag-faglige. Og endelig peger hun på, at en fælles opgave skal løses i et tværfagligt fælleskab, men 'på forskellige måder' og altså ud fra forskellige faglige perspektiver. En ideel tænkning omkring tværfagligt samarbejde.

Helt enkelt er det tværfaglige samarbejde dog ikke på undersøgelsens skole. I et interview med et team fremgår det, at der på skolen er en 'myte' om, at det tværfaglige samarbejde mellem pædagoger og lærere har været vanskeligt. En pædagog siger under et interview med et glimt i øjet til en lærer. 
- Jeg synes, vi har en meget åben snak om, at der er fagforskelle. Vi er ved at få slået spøgelset ned om, at lærere ikke kan lide pædagoger. Men pædagoger kan godt være lærere. Vi er blevet rigtig gode til at bruge hinandens faglighed.

Læreren i teamet bliver defineret som en af dem, der har den rolle at være kritisk over for lærer- og pædagogsamarbejdet. Hun siger:

- Her er der ikke et særligt godt Skole-SFO-samarbejde, siger myten, men det er ikke sådan i praksis. Det hænger jo lidt i væggene, og vi er selv med til at opretholde det

Læreren fortæller, at samarbejdet mellem lærere og pædagoger havde en svær start. Hun havde været med til at kæmpe for at SFO'en, da den kom på skolen skulle have sine egne lokaler, men det kom ikke igennem.

- Pludselig i august var hele SFO flyttet ned, da jeg møder i skole. Møbler, materialer, man kunne dårligt komme rundt på skolen. Det var... så kommer man ind på forholdet om, om pædagoger skal ind i undervisningen. Jeg synes ikke, pædagoger skal erstatte undervisningen. Eleverne har ret til at lære noget. Det er stadig svært at dele lokalerne.

Det at skulle dele lokaler og samarbejde omkring mål for eleverne, men ud fra forskellige professionelle perspektiver, er ikke nemt, men som det fremgår, er det noget, som fungerer bedre i praksis, end den myte, som er på skolen om, at samarbejdet er dårligt.

\section{Pædagogmedhjælpere i det tværfaglige samarbejde - i praksis}

Det er fremgået indtil nu, hvor stor en rolle pædagogmedhjælperne spiller i den daglige praksis. Både i forhold til at få klassefællesskabet til at fungere og i forhold til alle de praktiske opgaver og omsorgsmæssige og relationelle dimensioner, som et skoleliv indeholder. Afslutningsvist vil det blive eksemplificeret fra analysen af team-møder, hvordan pædagogmedhjælpere på møder bidrager med væsentlig indsigt.

Først og fremmest er det en tendens, at når møderne skifter til almindelige møder, så bidrager pædagogmedhjælpere lige så meget eller ofte mere end både pædagoger og lærere. Samlet viser analysen af møderne, at pædagogmedhjælperne anerkendes for det store ansvar, de tager i forhold til at få 'hverdagen 
til at glide', at få skabt rum for undervisning og også at bidrage i undervisningen

På møderne viser det sig, at pædagogmedhjælperne på især to områder bidrager med væsentligt erfaring og indsigt. For det første har de et blik for børnene og en forståelse af dem, som de tilfører diskussionen med pædagoger og lærere. Måske fordi de ikke har undervisningsansvaret eller ansvaret for pædagogiske mål, har de tid til at forholde sig til børnene i det hverdagsliv, som børnene lever på skolen. For det andet, har de et væsentligt bidrag ind i organiseringen af det tværfaglige samarbejde i praksis. Her to eksempler fra møder, der viser, hvordan disse kompetencer manifesterer sig.

Det første eksempel er fra et team-møde, hvor en lejrtur skal planlægges: To lærere, en lærervikar og en pædagogmedhjælper holder et planlægningsmøde om lejrturen to dage før, de skal af sted. Pædagogen i teamet er ikke med, idet hun er syg. Mødet starter med nogle meddelelser, som hurtigt er overstået og derfra går de over og planlægger tur til Kattinge. En lærer har været til skolens fælles koordinationsmøde om turen og læser op fra en seddel om, hvad der skal aftales og huskes. Derfra går teamet i gang med at planlægge turen. Når dialogen på mødet analyseres, træder pædagogmedhjælperen ind, som den, der har overblikket og tager lederskab over turen. Hun stiller en række forslag til, hvordan turen kan organiseres.

- Jeg foreslår, vi deler pakningen til turen i to. Elevernes ting kan vi pakke fredag og vores egne ting mandag. Vi kan jo inddrage eleverne

- Jeg synes, vi skal tage sæbebobler med - dem køber jeg - er der nogle andre, der vil stå for fiskenettet?

- Jeg kan godt blive tilbage og rydde op. Så har vi alle fået en tjans

- Vi bliver nødt til at købe en tur til en af drengene. Han elsker den svævebane og den dag, han er på Kattinge, har vi ikke svævebanen (drengen er begrænset voldsomt af sin funktionsnedsættelse og har kun ringe udbytte af de fleste aktiviteter på lejrskolen. Svævebanen er en aktivitet, som giver stor glæde)

- Jeg foreslår, at vi laver mad sammen med eleverne på bålet. Vi kan jo snitte nogle grøntsager og nogle krydderurter. Eleverne kan være med til at snitte

Ud over de citerede forslag fremgik det tydeligt på mødet, at pædagogmedhjælperen gik aktivt ind og bidrog til at organisere turen. I forhold til de øvrige team-medlemmer var hun den, som tog det største ansvar og kom med de fleste forslag. Da det kom til fordelingen af ansatte på børn, var det pædagogmedhjælperen, som lavede fordelingen. Det skal bemærkes, at mens hun lavede 
den, og de andre diskuterede med, var hun hele tiden den, der fik det sidste ord. Hun syntes at være den, der havde det største overblik.

På et tidspunkt skal tre elever diskuteres, fordi deres kontaktlærer har været sygemeldt og skal nu til at skrive status og elevplaner for de tre elever. Og hun har ikke haft mulighed for at følge dem tæt. Også her er det pædagogmedhjælperen, som først og fremmest bidrager med oplevelser af, erfaringer med og vurderinger af børnene og deres udvikling og læring. Her nogle eksempler:

- Han var med på Arken. Han gik igennem tunnelen, og det var godt for ham. Der var lys, farver, og det var sjovt. På Arken er der store lærreder, det var også godt for ham. Han har også haft fingrene i malingen - det var også godt for ham. Jeg har holdt penslen, men han har malet.

Kontaktlæreren noterer og siger, at målene er de samme som sidste år. Eleven er stærkt funktionsnedsat, sidder i kørestol og har intet sprog ud over blikkontakt. De vender sig til den næste elev, som skal diskuteres. En elev, som også er stærkt funktionsnedsat. Også her er det pædagogmedhjælperen, som først og fremmest bidrager.

- En pige fra klassen er lidt mere kommunikerende for tiden. Og hun er meget optaget af en af drengene i klassen. Når han er i nærheden, så kommunikerer hun mere end hun ellers gør. Hun vender sig mere mod andre for tiden, og det udvikler hende. Det er et rigtig godt eksempel på, at man ikke skal funktionsopdele.

\section{Opsamling}

De ovenstående eksempler er eksempler på, at pædagogmedhjælpere har en tæt kontakt til børnene og tager et stort ansvar for den daglige praksis - og for hverdagslivets organisering. Pædagogmedhjælperne får og tager en stor del af den samlede taletid, når mødet fx drejer sig om at evaluere børn, at evaluere pædagogiske og didaktiske situationer eller at planlægge en lejrtur. Pædagogmedhjælperne har et overblik over det pædagogiske og didaktiske hverdagsliv i skolen, over organisering, og de bidrager med indsigt om konkrete børn i konkrete situationer. 


\section{Kapitel 5. \\ Fra det specifikke til det generelle}

I dette sidste kapitel vil analysen af fokusgruppeinterview med tredive tillidsrepræsentanter for pædagogmedhjælpere på specialskoler over hele landet blive inddraget. Som omtalt før, er undersøgelsen foretaget på én specialskole, hvorfor det er relevent at afsøge, hvorvidt undersøgelsens analyser og fund er genkendelige i en bredere sammenhæng.

Analysen er foretaget på den måde, at de fire overordnede fund, som er beskrevet neden for, har været iagttagelsespunkter i analyse af fokusgruppeinterview. Det er undersøgt, hvor der er overensstemmelse, og hvor der er konflikt imellem undersøgelsen på én specialskole og en mere generel refleksion blandt repræsentanter fra flere skoler. Samlet tyder analysen af fokusgruppeinterview på, at der er en overbevisende stor overensstemmelse mellem analysens fund og de udsagn omkring roller, rollefordeling og samarbejde, som fremføres i fokusgruppeinterview. I formidlingen af analysen vil det blive fremhævet, som tilfører nyt til den ovenstående analyse.

Først eksempler på udsagn, som direkte bekræfter, at de foreløbige fund omkring roller (jævnfør kapitel 2), som blev præsenteret på TR konferencen, vakte genklang blandt tillidsrepræsentanterne:

- Jeg kan sagtens se mig selv i de roller, som er blevet beskrevet

- Jeg synes meget at det, der blev præsenteret, det passede godt ind i min hverdag

- Det kunne have været taget ud af vores klasse.

Fire overordnede fund i undersøgelsen

Her trækkes undersøgelsens fire overordnede fund (konklusioner) frem. Der træder en klar sammenhæng frem mellem det specialpædagogiske arbejdes karakter, den faglige selvforståelse på skolen og de roller, som lærere, pædagogmedhjælpere (og pædagoger) indtager og tildeles. En lang række opgaver må løses på en specialskole, som ikke i udgangspunktet knytter sig til undervisningen, men som er en forudsætning for, at der kan skabes et rum for undervisning. Det er løsningen af praktiske opgaver, som hygiejne og spisning. Det er overblikket over den samledes organisering og fordeling af roller og ansvar. 
Det er skabelsen af et fællesskab i klassen, hvor fællesskabet fungerer, og hvor den enkelte elev trives. Lærere på skolen anerkender nødvendigheden af, at disse opgaver løses, og tilkender pædagogmedhjælpere stort ansvar og betydning som vigtige samarbejdspartnere i relation til denne dimension.

1. I relation til Fibæk Laursens definition af professioners kamp om territorier, som refererer til en fagpolitisk kamp om løn og ansvarsfordeling, synes der ikke i praksis at være behov for at fastholde de sociale roller (Goffman), som henholdsvis lærer (forberedelse, udførelse og evaluering af undervisning) og pædagogmedhjælper (får ikke løn for forberedelse og er ikke ansat til at undervise). En anden måde at sige det på er, at det ikke hos lærere og pædagogmedhjælpere giver mening at holde disse roller adskilte i praksis. Lærere ved, at det er en forudsætning for at kunne realisere mål om undervisning, at der tages et fælles ansvar for 'alt det andet'.

2. På trods af denne overskridelse af roller i den daglige praksis, fastholder lærere og pædagogmedhjælpere, at det er læreres formelle ansvar og opgave at forberede undervisningen og at dokumentere elevers læring og mål for læring skriftligt. Men der er en forskel hos pædagogmedhjælperne i forhold til, hvorvidt eller i hvor stort et omfang de fastholder retten til ikke at gå ind på lærernes territorium. Altså ikke at forberede undervisning. Nogle ønsker at bidrage og at være inddraget i så stort omfang som muligt, fordi det ses som en forudsætning for et meningsfuldt arbejde, mens andre i højere grad ønsker at være friholdt.

3. En væsentlig rolle for pædagogmedhjælpere består i at støtte undervisningen og at undervise. På trods af, at lærere har det formelle ansvar for undervisningen, forudsætter fokus på individuelt tilrettelagt undervisning, at pædagogmedhjælpere underviser 1:1. Undersøgelsen viser, at pædagogmedhjælpere har en central kompetence, som kan knyttes til undervisningen, idet de trækker på praksisviden, der kan beskrives som en sans for, hvad der er rigtigt at gøre her og nu. Det er en viden, som består $i$ at have blik for eleverne, at kende eleverne godt, at gribe elever, at møde eleverne, at motivere eleverne og at skabe en relation, som gør det muligt at etablere et læringsrum. Pædagogmedhjælperne definerer selv deres kompetence, som en relationel kompetence og en social kompetence, som en betydningsfuld procesdidaktisk kompetence i undervisningen på en specialskole. 
4. I relation til deltagelse på team-møder viser undersøgelsen, at pædagogmedhjælpere ikke får rum til at bidrage på møder, når konsulenter indgår med specialiseret viden på møderne. Men når møderne drejer sig om håndteringen af individuelle elever, organisering af det specialpædagogiske arbejde i hverdagslivet og evalueringen af elever og undervisning, så bidrager pædagogmedhjælperne med stor indsigt. Lærere (og pædagoger) synes at anerkende pædagogmedhjælperes viden, som betydningsfuld i relation til håndteringen af pædagogiske og didaktiske situationer i hverdagen.

\section{Flere roller - fokusgruppeinterview}

Sammenholdes de fire fund med udsagn fra de samlet $4 \frac{1}{2}$ times fokusgruppeinterview træder en rolle hos pædagogmedhjælpere frem, som ikke er udfoldet i analysen fra 'undersøgelsens skole'. Samlet kan rollen betegnes som kammeratens, der vejleder i en bredere livskompetence for eleverne. Her nogle eksempler:

- Træning ud i livet. Så det er meget pædagogisk, når vi lærer dem en adfærd. Du lærer at vaske hænder, når du skal i køkkenet for eksempel. Når vi går op og handler ind, eller vi tager bussen, så kommer vi til at tale om den adfærd, som eleverne har. Altså hvordan man taler, hvis man står i kø ved en kasse $\mathrm{fx}$

- Det bliver sådan lidt kammeratlig storebror/lillebror-samtale, hvor man går ind og vejleder

- Man lærer dem godt at kende, og man kan måske godt, hvis de snakker om kærester, og hvad man kan lave sammen med en kæreste, forklare dem, at det deres kammerater fortæller dem, at de laver med en kæreste, er nødvendigvis ikke altid sandheden og sådan nogle ting. Det er jo ikke ret meget undervisning (hvad er to plus to minus tre?). Det er simpelthen en adfærdsændring, en opførselsændring, der skal i gang, og det kan pædagogmedhjælperne hos os blandt andet bidrage med

- Man ryger ud i nogle snakker og guider dem i livet.

Derudover peger mange pædagogmedhjælpere på en rolle, som er beslægtet, men har mere at gøre med praktisk dagligdags læring. Her to eksempler:

- Mit arbejdsliv er, som det blev beskrevet i oplægget [til interviewet], men jeg fokuserer også på den læring, som ligger i at gå over at handle og at tømme en opvaskemaskine, sortere tøj, lægge tøj sammen. Altså, social træning og praktisk træning 
- Der har lige været et tema, der hedder 'Min by'. Jeg står for noget sansemotorik en gang om ugen. Og så står jeg for en proces, der går ud på, at vi skal købe ind. Vi skal planlægge, hvordan man bager boller, læser en opskrift og måler og vejer. Det er ikke rigtige skoleopgaver, men der ligger en masse læring i det.

Pædagogmedhjælperne taler om, at de har et særligt blik for og kendskab til eleverne samt en særlig relation til eleverne, som uddannede pædagoger og lærere ikke har. En relation, som bliver tættere og mere uformel og som muliggør ovenstående former for læring. Her et udsagn, som viser, hvordan det udtrykkes:

- Noget som betyder meget, det er ikke defineret nogen steder. Vi (pædagogmedhjælpere) taler måske nogle gange på en ikke-pædagogisk måde. Hvis de render rundt og klør sig i skridtet, så er det bare direkte 'få nu den hånd op' eller 'få nu fingrene væk fra den stump'. Vi kan tale på en anden måde, hvor det ikke bliver så firkantet eller formelt. Nogle gange lukker man bare noget ud i stedet for at forklare. Det er knap så pædagogisk, men det virker jo. Nogle gange laver man noget sammen med eleverne og så opstår de snakker bare

- Det er tilliden og fortroligheden, vi har med eleverne, som gør det muligt at få en god snak. Jeg har en alder, hvor jeg ikke er så gammel, men gammel nok til at få respekt og at være en autoritet og en ven, og jeg er heller ikke for ung. Det er en fantastisk rolle at have, og man tænker ikke på, om man laver undervisning eller ej, for det er bare fedt, at eleverne kommer og spørger om sådan nogle ting. Pædagogmedhjælpere er måske nogle gange mere kammerater.

\section{Rollefordeling og samarbejde}

Der er ikke nyt at bringe ind i analysen i forhold til rollefordeling og samarbejdsformer. Dog træder der et lidt mere broget billede frem af, hvordan lærere og ledelser på forskellige specialskoler inviterer til og muliggør tværfagligt samarbejde. Nogle pædagogmedhjælpere beskriver, at der er et tydeligt hierarki på deres skole mellem uddannede og ikke uddannede og en rollefordeling, som følger de fagpolitiske spor. Det betyder, at to pædagogmedhjælpere ud af tredive nævner, at de ikke har noget at gøre med undervisningen overhovedet. De er praktiske pædagogmedhjælpere og står først og fremmest for mad, oprydning og pleje. Her et eksempel på det: 
- Det er hende, der har læreruddannelsen, og det kan jeg godt mærke. Der kan jeg virkelig mærke hierarkiet. Og det har jeg aldrig gjort før, aldrig

- Hos os har vi nok et hierarki med rollefordeling. Vi støtter op om undervisningen og bliver bedt om at sidde og hjælpe en elev med at arbejde, men det er primært os, der stopper ind i den ene ende og tager ud i den anden.

Det kommer tydeligt frem, at der er variation på specialskolerne i forhold til, hvordan ledelserne på skolerne støtter op om pædagogmedhjælpernes muligheder for at deltage i møder med lærere og pædagoger og dermed støtter inddragelsen af pædagogmedhjælpere i det tværfaglige samarbejde. Det viser sig, at nogle skoler giver pædagogmedhjælpere timer til at indgå på møder og dermed muligheden for at blive inddraget og for at bidrage til planlægningen og evalueringen af undervisningen og andre pædagogiske aktiviteter. Det er også tydeligt, at der hos pædagogmedhjælperne selv er en forskellig holdning til, hvorvidt man ønsker at indgå på møder og dermed mere ansvarligt og deltagende i undervisningens planlægning og evaluering. Nogle fastholder, at de ikke ønsker at gå ind i dette, med mindre de bliver betalt for det, mens andre finder det meningsløst ikke at blive inddraget og at bidrage. Netop her viser det sig, at den fagpolitiske dimension spiller en rolle.

Det har været en stor pointe i ovenstående analyse af én specialskole, at det ikke giver mening at adskille undervisning og 'alt det andet'. Det betyder, at det i praksis er svært at adskille rollerne og ansvarsfordelingen, når det kommer til praksis. Diskussionerne i fokusgruppeinterview afspejler denne kompleksitet. Altså, at den fagpolitiske diskussion om rolle- og ansvarsfordeling giver mening ind i en diskussion om løn, mødedeltagelse osv., men i den specialpædagogiske praksis er det svært at holde rollerne adskilte og for nogle ikke ønskværdig.

Efter denne korte redegørelse for analysen af fokusgruppeinterview vil rapporten blive afsluttet med nogle anbefalinger i forhold til pædagogmedhjælperes deltagelse i det tværfaglige samarbejde på specialskoler. Anbefalingerne bygger både på undersøgelsen af specialskolen og på de mere generelle diskussioner, som kommer frem i fokusgruppeinterview. 


\section{Afslutning med anbefalinger}

Undersøgelsen har givet mulighed for at indkredse empirisk, hvordan lærere og pædagogmedhjælpere samarbejder i og om praksis på en specialskole for elever med multiple funktionsnedsættelser. Det har været muligt at komme tæt på en bestemt praksis og derfra foretage nogle analyser, som er sensitive over for forskellige mere eller mindre subtile (jævnfør Goffman) og ikke sproglige dimensioner af samarbejdet i praksis. Undersøgelsens empiriske analyser vil sandsynligvis vække genkendelse hos lærere, pædagoger og pædagogmedhjælpere på landets specialskoler og vil muligvis rumme italesættelse af nogle dimensioner af deres samarbejde i praksis, som det i hverdagslivets ikke umiddelbart er nemt at sætte på begreb.

Det er et håb, at undersøgelsen og formidlingen af den vil kunne bidrage til at samarbejdet, og samarbejdsformer mellem forskellige faggrupper bliver diskuteret med udgangspunkt i samarbejdet i praksis og ikke med udgangspunkt i territoriale konflikter mellem professioner omkring arbejdsfelter og afgrænsninger. Indeværende undersøgelse har vist, at det er muligt, at samarbejde tæt uden at de enkelte professioner og faggrupper mister territorium. Undersøgelsen har samtidig vist, at det ikke nødvendigvis er nemt at samarbejde. Især relationen mellem pædagoger og lærere og mellem psykologer (og andre specialister) rummer udfordrende elementer. Samarbejdet mellem pædagoger og lærere er forholdsvist underbelyst i undersøgelsen, men som det er antydet, har det på den specifikke skole, som har været i fokus for undersøgelsen, været en historisk set vanskelig opgave at få samarbejdet mellem de to faggrupper til at fungere. I relation til samarbejdet mellem psykologer og øvrige faggrupper på specialskolen har undersøgelsen vist, at viljen til samarbejdet er stor, men at der eksisterer nogle modsætninger mellem forskellige kundskabstraditioner, som skaber udfordringer.

Det er en antagelse, at undersøgelsen kan generaliseres til andre skoletyper og eller institutionsformer. Fx vil undersøgelsen kunne danne afsæt for kommende diskussioner omkring undervisningsassistenter i folkeskolen. Der kan med udgangspunkt i indeværende empiriske fund peges på, at det kan give god mening at inddrage ikke uddannede undervisningsassistenter og eventuelt pædagoguddannede i folkeskolen også i relation til den større grad af diversitet i elevgruppen, som må formodes at opstå i folkeskolen omkring implementeringen af inklusion (placeringen af elever fra specialskoler i almenundervisnin- 
gen). Det viste sig, at undersøgelsens fund var generaliserbare for andre specialskoler med elevgrupper, der er i mindre omfattende vanskeligheder. Men samtidig må det fremhæves, at nogle af de fund, som undersøgelsen formidler omkring pædagogmedhjælperes rolle, også er bestemt af, at der på den specifikke skole, som undersøgelsen er foretaget på, gør sig nogle særlige problematikker gældende, fordi elevgruppen rummer elever, som er i omfattende vanskeligheder.

I relation til ovenstående perspektiveringer af undersøgelsens fund kan følgende anbefalinger udkrystalliseres fra undersøgelsen:

\section{Anbefalinger}

- Det tværfaglige samarbejde fungerer bedst, hvis der er en gensidig respekt og forståelse for hinandens faglige tilgange som forskellige. På undersøgelsens skole fremgik det, at et vellykket tværfagligt samarbejde baserer sig på en respekt for lærernes formelle ansvar fra pædagogers og pædagogmedhjælperes side, samt på læreres respekt for at andre faggrupper har andre faglige indfaldsvinkler, som kan berige det specialpædagogiske arbejde og undervisningen.

- Det specialpædagogiske arbejde kalder på procesdidaktiske dimensioner (det relationelle og sociale som en del af undervisningen), og samtidig hermed forudsætter individualiseret undervisning en tilførsel til team af støttende personale. Dvs. personale, som har forudsætningerne for at støtte op om undervisningen og at undervise. Det forekommer fagligt hensigtsmæssigt at ansætte eller at fastholde pædagogmedhjælpere, pædagoger og/eller undervisningsassistenter til netop at varetage disse roller.

- Det specialpædagogiske arbejde forudsætter samarbejde også omkring 'det at få hverdagen til at glide'. En række aftaler må indgås, og en række organiseringer må foretages, sådan at alle elevers behov dækkes, at fællesskabet fungerer, og at der skabes rum for undervisning. Både i relation hertil, men også i relation til pædagogmedhjælpernes deltagelse i undervisningsaktiviteter, kan det anbefales, at pædagogmedhjælpere får tid til at deltage på møder, hvor elever diskuteres, hvor undervisningen og andre pædagogiske aktiviteter planlægges og evalueres, og hvor organisering af og aftale om samarbejdet diskuteres. Det synes at være en nødvendig forudsætning for, at 'hverdagen glider', og at der skabes rum for undervisning.

- Endelig kan det anbefales, at konsulenter, der bidrager med specialiseret viden til specialskolerne, samarbejder med alle faggrupper omkring un- 
dervisningssituationer og pædagogiske situationer samt omkring eleverne og beskrivelsen af eleverne. Pædagogmedhjælpere har en særlig indsigt $i$ og kendskab til eleverne i situationer, som kan bidrage væsentligt i en faglig snak om den specialpædagogiske praksis. Det forudsætter, at konsulenter indtager en rolle, som består i at være sammen med alle faggrupper tilknyttet den konkrete undervisningspraksis. 


\section{Litteratur}

Barth, F. (2004). Manifestasjon og prosess, Det Blå Bibliotek.

Bayer, S. \& Petersen, J. S. (2004). Midt imellem - fortællinger om pædagogmedhjælpernes arbejdsliv, Forlaget Børn og Unge.

Bourdieu, P. (1997). Af praktiske grunde - omkring teorien om menneskelig handling, Hans Reitzels forlag.

Fibæk Laursen, P. (2004). Lærerne: Udfordrede, men stærke, Tidsskrift for skoleledere, nr. 7.

Goffman, E. (2009 (1959)). Jaget och maskerna - et studie i vardagslivets dramatik, Norstedts.

Hedegaard-Sørensen, L. (2009). "Specialpædagogikkens 'pædagogik' og 'didaktik'". Tidsskriftet Specialpædagogik, nr. 5, årg. 29.

Hedegaard-Sørensen, L. (2010a). Pædagogiske og didaktiske rum for elever med diagnosen autismespektrumforstyrrelse, læreres selvforståelse og handling $i$ (special)pædagogisk praksis. Ph.d.-afhandling. København: DPU.

Hedegaard-Sørensen, L. (2010b). Beskyttet eller inkluderet - en falsk modsætning, Storebjergundersøgelsen

(http://www.halsnaes.dk/SkoleBoernepasning/Skoleomraadet/Specialundervisn ing/).

Hedegaard-Sørensen, L. \& Tetler, S. (2011). Situated professionalism in Special Educational Practice, Educating preservice teachers for special education/inclusive education. In: Mattsson, Rorrison \& Vidar (ed.) "A Practicum Turn in Teacher Education".

Hippe, H. og Hiim, E. (2001). Å utdanne profesjonelle yrkesytøvere. Oslo: Gyldendal. 
Hippe, H. og Hiim, E. (2006). Praksisveiledning i lærerutdanningen, en didaktisk veiledningsstrategi. Oslo: Gyldendal, Akademisk.

Hiim, H. \& Hippe, E. (2009). Undervisningsplanlegging for yrkesfaglærere. Oslo: Gyldendal, Akademisk.

Illeris, K. (2006). Læring, Roskilde Universitetsforlag.

Kristiansen, S. \& Krogstrup, H.K. (1999). Deltagende observation, introduktion til en forskningsmetode. Hans Reitzel forlag.

Lindebladet, maj 2009, nr. 2. Tema: 'Børn med særlige behov'.

Moos, L. (2004) Relationsprofessioner, Tidsskrift for skoleledere, nr. 7.

Polkinghorne, D. E. (2004). Practice of the human sciences - the case for a judgementbased practice of care. State University of New York Press.

Schön, D.A. (2001). Den reflekterende praktiker, hvordan professionelle tænker, når de handler. Århus: Forlaget Klim.

Tetler, S., Baltzer, K., Hedegaard-Sørensen, L., Boye, C. \& Liv Andersen, G. (2009). "Pædagogiske vilkår for elever i komplicerede læringssituationer" I: Egelund, N. \& Tetler, S. (red.). Effekter af specialundervisningen, pædagogiske vilkår for elever $i$ komplicerede læringssituationer og elevernes faglige, sociale og personlige resultater. København: Danmarks Pædagogiske Universitetsforlag.

Uljens, M. (1993). Den pedagogiska flugan - en anaysmodell för didaktisk handlande. Vasa: Publikationer från Pedagogiska fakulteten vid Åbo Akademi nr. 2. Uppsala: Sociologiska Insitutionen, Uppsala Universitet.

Uljens, M. (red.) (1997). Didaktik. Lund: Studentlitteratur. 


\section{Bilag 1. \\ Interviewguide}

Projekt 'Samarbejdets kunst' - Interviewguide

- Den specialpædagogiske praksis - hvordan beskrives det daglige arbejde? (kort)

- Beskriv en typisk dag?

- Hvornår starter dagen, hvordan starter den, hvilke daglige rutiner osv.

- Begrund?

- Uddyb?

- Faglig selvforståelse - hvordan tales om 'det specialpædagogiske arbejde'? (kort)

- Hvordan beskriver I på skolen (formuleret i dokumenter) de overordnede mål for det specialpædagogiske arbejde?

- Hvordan beskriver du/I målgruppen? Hvordan vil I karakterisere eleverne/børnene?

- Hvordan tænker I undervisning?

- Hvordan er forholdet mellem de faglige, sociale og personlige mål?

- Hvordan praktiserer I (og forstår) specialpædagogik - dvs. hvordan adskiller I jer fra folkeskolen?

- Hvad er forholdet mellem specialpædagogik og almindelig pædagogik/undervisning?

- Opgavefordeling og forskellige roller? (gives meget tid og uddybning)

- Først henvendt til 'pædagogmedhjælperen':

- Hvordan vil du beskrive din rolle?

- Hvordan vil du beskrive dine personlige/faglige mål med dit arbejde?

- Hvordan adskiller du dig fra pædagoger - funktioner og når I samarbejder?

- Hvordan adskiller du dig fra lærere - funktioner og når I samarbejder?

- Hvad er fordelene, som du ser det, ved at være flere faggrupper? 
- Hvorfra har du tilegnet dig dine kompetencer?

- Hvor har du arbejdet før?

- Hvor længe har du arbejdet her?

- Så henvendt til 'læreren':

- Hvordan vil du beskrive din rolle?

- Hvordan vil du beskrive dine personlige/faglige mål med dit arbejde?

- Hvordan adskiller du dig fra pædagoger - funktioner, og når I samarbejder?

- Hvordan adskiller du dig fra pædagogmedhjælpere - funktioner, og når I samarbejder?

- Hvad er fordelene, som du ser det, ved at være flere faggrupper?

- Hvordan og hvorfor arbejder du som lærer på specialskole?

- Hvor har du arbejdet før?

- Hvor længe har du arbejdet her?

- Samarbejdet? (gives meget tid og uddybning)

- Hvordan, hvor og hvornår aftaler I, hvordan I fordeler roller?

- Beskriv jeres arbejdsfordeling?

- Hvad begrunder jeres arbejdsfordeling - profession, arbejdstid, løn, fagforening?

- Beskriv jeres samarbejde? - Konkrete situationer, hvor der samarbejdes?

- Samarbejder I sådan, som I aftaler det?

- Kan man aftale alt i et samarbejde - hvad kan ikke aftales?

- Hvordan planlægger I samarbejdet?

- Planlægger I på møder eller i team praksis?

- Forholdet mellem planlægning og udførelse - planlægges i detaljer, hvornår?

- Hvordan forbereder I aktiviteter sammen?

- Har I haft konflikter?

- Hvordan løser I dem?

- Hvordan evaluerer I samarbejdet eller gør I? 


\section{Bilag 2. \\ Fokusgruppeinterview \\ - Roller og interviewguide}

Arbejdspapir til TR-konference d. 13. maj/2011, Lotte Hedegaard Sørensen \& Søren Langager

- Roller for pædagogmedhjælpere (se evt. vedlagte fortællinger om roller). At assistere undervisningen - at være med, når der undervises og med fokus på at støtte elever i at indgå og at få undervisningen til at glide uden for mange afbrydelser. At forestå individuel undervisning - at vejlede og støtte enkelte eller flere elever, når de arbejder individuelt.

- At gå væk fra klasselokale eller lokale, hvor der undervises, sammen med en eller flere elever, når elever menes ikke at kunne indgå.

- At stå for pleje, hygiejne, mad m.m.

- At undervise - fx gennemgå kontaktbøger, stå for billedkunstundervisningen, gennemgå dagen, snakke om fælles, sociale arrangementer med en gruppe elever.

Diskuter følgende spørgsmål om roller og samarbejde:

- Diskuter, hvilke af ovenstående roller, som dominerer på jeres arbejdspladser?

- Er der andre roller for pædagogmedhjælpere, I kender til eller selv indtager?

- Diskuter, hvad det er, som adskiller pædagogmedhjælpere fra pædagoger og lærere - når I arbejder? Hvilke opgaver varetager I ikke? Og med hvilke begrundelser?

- Beskriv jeres samarbejde med lærere og pædagoger?

- Hvordan, hvornår og hvor forbereder I jer sammen?

- Hvordan, hvornår og hvor aftaler I rollefordeling?

- Kan man forberede alt - hvad kan ikke aftales?

- Hvornår evaluerer I? 
- $\quad$ Roller i praksis

- Assistere undervisning:

- Alle elever i denne gruppe samles i et lokale rundt omkring et bord. Dvs. to elever sidder i deres kørestole et stykke væk fra bordet, men dog som en del af gruppen. Begge disse elever er i omfattende funktionsnedsættelser, har ingen verbalt sprog og i meget ringe omfang kropssprog, fordi deres kroppe ikke fungerer. De kommunikerer hovedsageligt gennem blikke. Læreren tager ledelsen af morgensamlingen. Hun sætter sig foran alle eleverne. Pædagogmedhjælper sætter sig foran en elev, som er meget højrøstet. Hun er 14 år, men er aldersmæssigt svarende til 1,5 år, får jeg at vide. Hun råber højt hele tiden, skubber sig væk fra bordet og rokker frem og tilbage. Hun har ikke noget verbalt sprog. To andre elever har verbalt sprog og sidder ikke i kørestol. En anden dreng sidder i kørestol, men kan selv køre den frem og tilbage og har evnen til at kommunikere verbalt - om end noget usikkert. Eleverne sidder rundt omkring det samme bord og en lærer sidder foran dem. Læreren snakker om forår. Hun viser nonverbalt, at hun bliver generet af de meget høje lyde og den fysiske uro, som en af eleverne laver. Pædagogmedhjælperen sætter sig over til pigen og stryger hende over ryggen og på håret.

- Undervise 1:1:

- Pædagogmedhjælper går i gang med at arbejde med en elev - de arbejder med at tælle. Pædagogmedhjælper sidder ved siden af pigen ved hendes arbejdsbord og arbejder 1:1 med hende og med en opgave, som er særligt udviklet til hende. Alle elever har en reol med en masse hylder, og på hver hylde ligger en arbejdsopgave, som er udviklet særligt til dem og i samarbejde med talepædagogen. Det er først og fremmest lærerne, som står for udviklingen af arbejdsopgaverne, men pædagogmedhjælperen i denne gruppe er med i dette arbejde. Da pædagogmedhjælper har arbejdet 1:1 i 10 minutter med en pigen, siger hun til hende, at nu skal hun holde frikvarter, for pædagogmedhjælperen skal arbejde med en anden elev. Pædagogmedhjælper spørger pigen, om hun vil høre musik $i$ et af lokalerne ved siden af og sidde i en sækkestol. Uden tydeligt signal om, at det vil hun gerne, følges hun ind i et rum, ved siden af klasserummet. Pædagogmedhjælper hjælper hende med at finde cd, tænde for musikken og sætte sækkestolen frem. 
- At gå væk fra undervisningen med enkelte børn:

- Det er morgensamling og dagen gennemgås. Det er en særlig dag i dag, fordi mange elever er fraværende. Der er 2 lærere, 1 pædagogmedhjælper og 4 elever. 'Der er ikke meget ventetid i dag', siger en af lærerne. Hun siger også, at så kan de rigtig får arbejdet. Lærer fortæller eleverne og samtidig pædagogmedhjælper - hvordan dagen er tilrettelagt. Mens hun fortæller, begynder en pige at sige, at hun ikke gider lave skolearbejde i dag. Hun vil spille computer. Lærer siger: 'Nu er det skole, så det kan du ikke - du må vente til, det er frikvarter'. Lærer beder hende om at sætte sig ved fællesbordet. Det vil hun ikke - hun bliver siddende ved sit eget bord - lidt væk fra fællesbordet. Lærerne lader hende sidde der lidt og går i gang med det, som de havde planlagt. De snakker om nogle maleraktiviteter, om billedudstilling, de skal holde, og om en tur, de har været på - på Arken. Dagen - formiddagen - gennemgås igen, men nu mere med fokus på det, der skal arbejdes med, og hvordan det kommer til at foregå. De skal arbejde individuelt 1:1 og har på skift en lærer til rådighed. De skal lave matematik og dansk. Pædagogmedhjælperen skal ikke være til stede. Hun skal til svømning med en af eleverne. Eleven plejer at være i sproggruppe denne formiddag, men da en anden elev ikke er i skole, er det aflyst til fordel for svømning.

- At stå for pleje, hygiejne, mad m.m.:

- Morgensamling skal i gang. En gruppe elever - flere i kørestol - er i et lille lokale sammen og sammen med en hel masse voksne. Der snakkes om, at der er særligt mange voksne den dag. Så mange, at det er lige ved, at vi går i vejen for hinanden, siger en. En lærer stiller sig op ved en tavle for at gennemgå dagen. To piger i lokalet omkring et fællesbord er meget højtrøstede og rokker frem og tilbage. En af pigerne forsøger at slå sin sidekammerat. En vikar lykkes med, lige inden pigen rammer, at skubbe hende tilbage (hun sidder på en stol, der har hjul på, men ikke en kørestol). Alle ansatte i lokalet forsøger at få ro på eleverne. Det lykkes efter et stykke tid, at få alle til at være stille. Læreren gennemgår dagen. Pædagogmedhjælperen er ikke med til morgensamling. Hun er travlt beskæftiget med at få Emilies sondemad gjort klart. Mens morgensamlingen er i gang, kører pædagogmedhjælperen Emilie ind i hendes kørestol og stiller hende i lokalet. Nu skal kontaktbøgerne gennemgås.

- At undervise:

- Denne gruppe er også delt i to, når undervisningen gennemføres. På et tidspunkt kaldes eleverne til deres respektive grupper/lokaler, for nu skal dagen gennemgås inden morgensang klokken 09.00. Jeg observerer i 
et lokale, hvor en lærer og en pædagogmedhjælper skal være sammen med 4 børn denne formiddag. Børnene, lærer og pædagogpædagogmedhjælper samles omkring et fællesbord. Pædagogmedhjælper læser børnenes kontaktbøger op for dem og snakker lidt med dem, om de aktiviteter fra dagen i går hjemme, som står beskrevet i bøgerne. Inden aktiviteten går i gang aftales det, hvordan rækkefølgen af gennemgangen af kontaktbøger skal være, og hvordan proceduren er ift. hvem der vælger bøger. Pædagogmedhjælper forklarer, at det er de voksne som skal bestemme rækkefølgen og som vælger, fordi Oskar dagen før var blevet rigtig sur over noget $\mathrm{i}$ forbindelse med gennemgangen af kontaktbøger. Pædagogmedhjælper spørger i løbet af samtalen læreren, om det er de voksne, som skal bestemme. Læreren siger, nej. Hun tager over eller tager ledelsen af gennemgangen af kontaktbøger. Læreren forklarer Oskar, at først skal Laura vælge, og så skal Oskar vælge til sidst. Pædagogmedhjælperen går i gang med at bede Laura om at vælge. Hun vælger sin bog. Pædagogmedhjælper gennemgår, læser og snakker om det, der står i Lauras bog. Det er pædagogmedhjælperen, der leder hele aktiviteten, mens læreren supplerer undervejs. De sidder begge omkring bordet sammen med de 4 elever. 
Specialskolernes organisering af den daglige specialundervisning og anden specialpœdagogisk bistand er et område, der er sammensat med hensyn til den faglige forståelse af de grundlaeggende opgaver i forhold til de varierede grupper af elever, og hvad angår medarbejdergrupper spcender fra de specialuddannede larere over pœdagoger til pœdagogmedhjœlpere uden formelle kompetencegivende uddannelsesmassige baggrunde.

Hvad der tegner sig af mønstre og tendenser omkring de faglige forståelsesrammer, samarbejdsrelationer og opgave- og ansvarsfordeling i tilknytning til undervisningsdelen, er forskningsprojektet et bidrag til øget indsigt i med sœrligt fokus på samarbejdet mellem speciallœerere og pœdagogmedhjcelpere.

Undersøgelsen er tilrettelagt som en kvalitativ empirisk undersøgelse med observationer af praksis i samarbejdet suppleret med interview på forskellige afdelinger på en specialskole 